\title{
ASKING FOR IT? \\ MORAL HAZARD, REBELLION AND \\ GENOCIDAL VIOLENCE IN DARFUR
}

by

KELLY WHITTY, B.A.

\author{
A thesis submitted to \\ The Faculty of Graduate Studies and Research \\ in partial fulfillment of \\ the requirements for the degree of \\ Master of Arts \\ The Norman Paterson School of International Affairs
}

Carleton University
Ottawa, Ontario

16 APRIL 2009

(C) 2009, KELLY WHITTY 
Library and

Archives Canada

Published Heritage

Branch

395 Wellington Street

Ottawa ON K1A 0N4

Canada
Bibliothèque et

Archives Canada

Direction du

Patrimoine de l'édition

395 , rue Wellington

Ottawa ON K1A 0N4

Canada

Your file Votre référence

ISBN: 978-0-494-51970-7

Ourfile Notre référence

ISBN: 978-0-494-51970-7

NOTICE:

The author has granted a nonexclusive license allowing Library and Archives Canada to reproduce, publish, archive, preserve, conserve, communicate to the public by telecommunication or on the Internet, loan, distribute and sell theses worldwide, for commercial or noncommercial purposes, in microform, paper, electronic and/or any other formats.

The author retains copyright ownership and moral rights in this thesis. Neither the thesis nor substantial extracts from it may be printed or otherwise reproduced without the author's permission.
AVIS:

L'auteur a accordé une licence non exclusive permettant à la Bibliothèque et Archives Canada de reproduire, publier, archiver, sauvegarder, conserver, transmettre au public par télécommunication ou par l'Internet, prêter, distribuer et vendre des thèses partout dans le monde, à des fins commerciales ou autres, sur support microforme, papier, électronique et/ou autres formats.

L'auteur conserve la propriété du droit d'auteur et des droits moraux qui protège cette thèse. $\mathrm{Ni}$ la thèse ni des extraits substantiels de celle-ci ne doivent être imprimés ou autrement reproduits sans son autorisation.
In compliance with the Canadian

Privacy Act some supporting forms may have been removed from this thesis.

While these forms may be included in the document page count, their removal does not represent any loss of content from the thesis.
Conformément à la loi canadienne sur la protection de la vie privée, quelques formulaires secondaires ont été enlevés de cette thèse.

Bien que ces formulaires aient inclus dans la pagination, il n'y aura aucun contenu manquant.

\section{Canadä}




\begin{abstract}
Two rebel groups cooperatively initiated a political rebellion in Darfur in early 2003. They appear to have done so in conditions in which success was unlikely and genocidal violence against civilians was likely. This research aims to improve the historical explanation of the 2003 conflict in Darfur by exploring whether Kuperman's (2005, 2006, $2008 \mathrm{a}, 2008 \mathrm{~b}$ ) theoretical framework of the moral hazard of humanitarian intervention explains this empirical puzzle. In particular, the research tests whether the Sudan Liberation Army/Movement, one of two rebel movements, intentionally provoked a humanitarian catastrophe in Darfur in order to attract international intervention and advance its political interests. Limited information available through English-language publications, contemporaneous media and in-person interviews indicates the hypothesis does not compellingly explain why the insurgents rebelled when they did. The evidence tentatively suggests the foco theory of rebellion is a more useful tool to understanding the rebels' strategic vision at the onset of the conflict. In addition, the Naivasha peace talks appear to have had a demonstration effect on Darfuri rebels and explain the timing of the rebellion.
\end{abstract}




\section{ACKNOWLEDGEMENTS}

I dedicate this research project to Louis Guay, my thesis advisor, who survived a harrowing kidnapping between December 2008 and April 2009. He brought to this project invaluable experience and expertise on the question of Darfuri rebel decisionmaking. I am most grateful for his recent release.

During the summer of 2007, I took a leave of absence from my job in the office of Senator Romeo Dallaire to travel to Sudan. At the time I was working on the "Darfur file" in the Senator's office, tasked with generating greater awareness of the crisis and support for increased Canadian intervention in the region; I was busy organizing conferences and rallies to this end. Alan Kuperman's (2005) controversial argument challenged the work I was doing by suggesting that efforts to promote international humanitarian intervention in situations of genocide and mass atrocities was not part of the solution for the people of Darfur, but rather, part of the problem. Motivated by the desire to investigate this, and simply spend time in a country which occupied so many of my waking hours, I set off to Khartoum. Doing so was one of my better decisions. Sudan is a fascinating, multilayered place and I was able to learn about the country, the conflict, the people and their history. Most importantly though, I gained a little bit of perspective on how much I did not understand about Sudan and had not bothered to ask until then.

I would not have undertaken this project, nor could I have made it to the end, without the support and guidance of family, colleagues and friends. First and foremost, I must thank my parents! They handled early morning panicked phone calls from international airports (not the first I might add); endured living with me during the writing process, which, at times, was no small feat; and provided wisdom and perspective (for free!). Thank you for pushing me to take on this project.

I would also like to thank Professor James Ron, my thesis supervisor, for his support and guidance. It is in his Human Security class at the Norman Paterson School of International Affairs that I first read Kuperman's theory of the moral hazard of humanitarian intervention. Thank you for encouraging me to go to Sudan, for pushing me to the end, and for providing some perspective on the value of this project. I would also like to thank Professor Jean Daudelin, who picked up the project when it was floundering. I am also grateful for the support of Aubrey Morantz, who, on very short notice, in the absence of Louis Guay, agreed to help me with this research and provided great insight into the international community's intentions and actions in Sudan. Thank you as well to Vivian Cummins for her patience and formatting/editing advice.

Finally, I would like to thank my friends. Jonas Pedersen, Jan Eckendorf and Philippe Martin: you not only provided advice and endured much rambling about this project, you responded to my pleas for editing help on very very short notice. Thank you! To everyone else who is important to me, merci. 


\section{TABLE OF CONTENTS}

Acceptance Sheet

Abstract

1. Introduction

2. The Puzzle

3. The Hypothesis

4. Methodology

5. Policy relevance of the research

6. Main arguments/findings

7. Overview

\section{CHAPTER 2: Setting up the Puzzle}

1. Introduction

2. An overview of Sudan

3. Darfur's place within Sudan

4. The rebellion

5. Puzzle: sub-optimal conditions

6. The question

7. Situating the question within the literature on Sudan

8. Conclusion

\section{CHAPTER 3: Methodology}

1. Introduction

2. Objective: Theory testing

3. Single Case study using process-tracing

4. Operationalization of my hypothesis

5. Sources of evidence

6. Field Work

7. Evidentiary value of the data collected through interviews

8. Conclusion

CHAPTER 4: Kuperman's Theoretical Framework

1. Introduction

2. Theoretical framework: the moral hazard of humanitarian intervention

3. Evidence of suicidal rebellions and the moral hazard of humanitarian intervention

4. Critique of Kuperman's theoretical framework

5. Conclusion 
1. Introduction

2. The Hypothesis

3. Testing the Hypothesis

4. Evidence supporting the hypothesis

5. Evidence undermining the hypothesis

6. Analysis

7. Conclusion

CONCLUSION

1. Introduction

2. The findings

3. Limits of this research

4. Policy implications

ANNEX 2: ETHICS APPROVAL 


\section{LIST OF TABLES}

Table 1: Explanations for Rebellions by Groups Vulnerable to Genocidal Retaliation

Table 2: The model's assumptions and predictions 


\section{CHAPTER 1: INTRODUCTION}

\section{Introduction}

Over the past six years, Western readers have learned of horrors taking place in Darfur, an inhospitable region of the Republic of the Sudan. Western mainstream media initially condensed the complexities of the conflict into a few broad strokes: Arab militia, armed to the teeth, perpetrating genocide and mass atrocities on behalf of the government of Sudan, and black African women and children suffering horrendous sexual and genderbased violence at the hands of the aforementioned men (Kamal el-Din 2007, 93). These images summarize how most Western observers understood the conflict.

Like every story, this armed conflict has at least two sides. Missing from the above description are the Darfuri rebel groups that instigated violence in early 2003. Research on the causes of the conflict in Darfur ${ }^{1}$ posit long-term government neglect of the region, political manipulation of Darfuri elites by Khartoum and increasing competition over resources due to ecological degradation as the motivators of conflict (Flint and de Waal 2005; Prunier 2005; Burr and Collins 2007; Daly 2007). However, comparatively little attention has been paid to the rebel movements' decision to instigate conflict when they did. While these accounts provide compelling reasons as to why Darfuri rebels would have wanted to rebel against the Sudanese government, they do not appear to be sufficient to explain why they did given the likelihood of disproportionate retaliation and marginal probabilities of success. This paper attempts to shed light on this empirical puzzle by

\footnotetext{
${ }^{1}$ In 1916, the independent sultanate of Darfur was annexed to Sudan. In 1994, the Sudanese government divided Darfur into three states in 1994 (North, West and South Darfur) in order to undermine the region's strongest and historically most prominent tribe, the Fur (Abdul-Jalil et al. 2007). In this paper, "Darfur" refers to the region encompassing all three states.
} 
examining the application of Kuperman's hypothesis of the moral hazard of humanitarian intervention to the onset of conflict in Darfur.

\section{The Puzzle}

An initial overview of the existing English-language literature on the conflict provides some information on these forces and the circumstances in which they rebelled. Two rebel movements cooperatively launched the conflict in early 2003: the Sudan Liberation Army/Movement (SLA) ${ }^{2}$ and the Justice and Equality Movement (JEM). These groups cooperatively instigated a political rebellion by attacking government positions in Darfur and publicising their political demands (De Waal and Flint 2005, 79). Their stated objectives were to end the political and economic marginalization of Darfur within Sudan and bring security to the region (SLA/M 2003).

This research will focus exclusively on the SLA's intentions and actions at the onset of the conflict so as to simplify an already complex situation. I chose to focus on the SLA because they attacked the government first, have more support throughout Darfur, and are led and funded by Darfuris. As I will detail further on, their claims to being the "authentic" Darfuri rebel movement (at the beginning of the conflict) are perceived as more legitimate than JEM's by most scholars and practitioners of the conflict (Tanner 2005, 21; Flint 2007, 153). Disregarding JEM does not significantly impact the validity of my analysis.

Despite the strength of the rebels' initial attacks against the government, evidence suggests they did not have the ability to achieve their political objectives militarily. The

\footnotetext{
${ }^{2}$ This group was initially named the Darfur Liberation Front (DLF); they became the Sudan Liberation Army/Movement in February 2003 (Flint and de Waal 2005, 82).
} 
Sudanese military and proxy militia were better equipped, greater in number and were more experienced in fighting given the extended conflict in south Sudan (Johnston 2007, 364; Daly 2007, 4). In addition, the government's use of genocidal retaliation appears to have been predictable as such military tactics had been widely used by the government to fight the Sudan People's Liberation Army (SPLA), the south Sudanese rebel group which fought the government for from 1983 until 2005 (ICG 2002a, 115-120). Flint and de Waal note:

In the [southern] oilfields, the orders were identical: 'If you see a village you burn that village. If you see a civilian, you kill that civilian. If you find a cow, that cow is your cow.' With the same men in power in Khartoum, the orders issued in Darfur could only be the same. $(2005,106)$

Finally, in November 2002, Ali Osman Taha, an advisor to President Bashir and senior negotiator at the Naivasha talks travelled to Darfur and publicly and explicitly "made clear that a military solution was on the cards and would be ruthless; Darfur 'would be pulled back for many years' if the rebels followed the example of the SPLA" (Flint and de Waal 2005, 98; see also Prunier 2005, 91). The rebels did not heed this advice though.

While the conditions for mobilization existed in Darfur, the SLA's decision to rebel without apparent reasonable chances of success is puzzling, and raises the question: why did the SLA rebel leaders choose to rebel in conditions that were grossly unfavourable to their success, at great risk to themselves and their civilian support base?

\section{The Hypothesis}

The theoretical framework of the moral hazard of humanitarian intervention developed by Kuperman $(2005,2006,2008 a, 2008 b)$ appears to help explain the empirical puzzle. Kuperman applies rational deterrence theory to intra-state actors to 
explain why subjugated groups rebel against militarily superior states which have threatened genocidal retaliation, rebellions he characterises as suicidal. He argues that there are five possible explanations of such behaviour (see Table 1, Kuperman 2005, 2008a). First, the rebels may not perceive as credible the state's threat to retaliate and, therefore, rationally choose conflict. Second, the rebels may expect victimization against their identity group anyway and, therefore, believe they have nothing to lose by rebelling. Third, the rebels may be blind to the military superiority of the state and believe they have the capabilities to achieve their political objectives on their own (without outside intervention). Fourth, the rebel leaders may expect the international community to intervene should a humanitarian catastrophe occur, and assume such intervention would enable victory at (what they consider) tolerable cost in military and civilian lives. Finally, fifth, the leaders of the subjugated group may not act as rational actors.

Table 1: Explanations for Rebellions by Groups Vulnerable to Genocidal Retaliation

1. Do not perceive credible threat by state to retaliate

2. Expect victimization anyway, so nothing to lose

3. Expect victory at tolerable cost without intervention

4. Expect intervention to enable victory at tolerable cost

5. Do not behave as unitary rational actors

Kuperman is interested in the fourth scenario in which rebels expect international intervention to enable victory at tolerable cost. He argues this expectation is rational because of the emerging norm of international humanitarian intervention. Since the end of the Cold War, the international community - defined as United Nations Member States and state-based organizations (Black and Williams 2008, 2) - has increasingly intervened in sovereign states in order to protect civilians from egregious abuse (Murphy 1996). While intervention is not a new phenomenon, doing so for explicitly and exclusively 
"humanitarian" reasons is. Such actions and their rhetorical endorsements have arguably created a norm, defined by the Oxford English Dictionary (1993) as "what is expected or regarded as normal, customary".

Based on in-depth case studies of the Bosnian Muslim and Kosovo Albanian rebellions in 1992 and 1999, respectively, Kuperman argues that this norm can create a moral hazard for some subjugated rebel leaders. Moral hazard, a concept borrowed from economics, is "the phenomenon in which the provision of protection against risk unintentionally promotes irresponsible or fraudulent risk-taking, and thereby perversely increases the likelihood of the undesired outcome" (Kuperman 2008a, 50). In this case, the international community would be perceived as the "insurance company" by subjugated rebel groups because its behaviour and rhetoric have created the expectation that it will share the costs of the rebellion should massive retaliation against civilians occur. Two scenarios are possible: rebel leaders can respond to this incentive by acting fraudulently and intentionally provoking violence against civilians in order to garner international attention; or, they can act irresponsibly by taking more risk because they expect the international community to act as a safety-net should "things go wrong". Both scenarios increase the likelihood of genocidal violence which would not have occurred were it not for the norm of international humanitarian intervention. ${ }^{3}$

The causal variable in Kuperman's hypothesis is the presence of moral hazard - the expectation of intervention. While Kuperman argues that the broad norm of international intervention can create moral hazard in some cases, Crawford (2005) makes the case that moral hazard is most acute when identifiable international actors set a concrete precedent

\footnotetext{
${ }^{3}$ For a discussion of why the norm is more likely to impact the incentives of rebel movements than those of states (and not deter states from retaliating with genocidal violence) see Kuperman (2008a, 35).
} 
which directly impacts the incentives of a specific subjugated rebel movement. Such interventions are likely to be, and be perceived by surrounding rebel groups as, tangible examples of the norm of international humanitarian intervention.

A preliminary evaluation of the five explanations for suicidal rebellion, deduced from rational deterrence theory (Table 1), reveals that Kuperman's hypothesis appears be a useful tool to explain the occurrence and timing of the conflict in Darfur. First, precedents for genocidal retaliation had been set in Sudan during the north-south conflict: Darfuri rebels would therefore have had reason to perceive as credible the government's threat to retaliate. Second, while structural violence and general insecurity were commonplace in Darfur, rebel leaders would have anticipated that violence against civilians would increase if they attacked the government. Third, the rebels' military inferiority relative to the government suggests victory on their own was unlikely. Fourth, given the international community's involvement in the north-south peace negotiations, which was embedded in the international rhetoric on humanitarian intervention, the rebels would have had reason to believe the international community would intervene should a humanitarian catastrophe occur in Darfur. The fifth alternative - that the rebel leaders did not behave as a unitary rational actor - is problematic as there are grounds on which to question the unitary and rational nature of the Darfuri rebel leadership. For example, infighting among the tribes within the movement, notably the Fur and Zaghawa, created divides within the SLA leadership (Flint and de Waal 2005, 86) and may have led to nonunitary and/or irrational decision-making. If the unitary rational actor assumption fails, Kuperman's model is unlikely to be helpful in explaining the puzzle. ${ }^{4}$ My choice to limit my research to the SLA's decision to instigate conflict mitigates this problem. As

\footnotetext{
${ }^{4}$ See Footnote 26 for a discussion of this criterion.
} 
Kuperman notes, should there be decisive evidence supporting one of the four other alternatives, then it is reasonable to assume the rebels were acting as if they were a unitary rational actor $(2008 \mathrm{a}, 55)$.

This paper will explore whether the theoretical framework of the moral hazard of humanitarian intervention helps explain why the Sudan Liberation Army/Movement leaders instigated rebellion in Darfur in conditions in which success appeared highly unlikely. To do so, I formulated a hypothesis that captures the central theses of the framework - moral hazard and suicidal rebellion - as they apply to this conflict. I have assumed that the international community's involvement in the north-south peace agreement was, and was perceived as, a concrete precedent for international humanitarian intervention in Sudan. I have also chosen to test whether the SLA rebels acted fraudulently: whether they cynically created a humanitarian catastrophe to advance their political objectives. The hypothesis is:

International humanitarian intervention created a moral hazard that altered the strategic incentives of the Sudan Liberation Army/Movement. As a result, the rebel group's leaders intentionally launched a suicidal rebellion against the government of Sudan in early 2003 because they believed international humanitarian intervention would enable victory at tolerable cost.

\section{Methodology}

Examining the applicability of Kuperman's theory to this single case-study will improve the historical explanation of the onset of the conflict, providing useful insights for political scientists, international diplomats and conflict practitioners. George and Bennett (2005) argue that the most effective research method for this exercise is processtracing, which aims to empirically identify and describe the intervening factors and causal processes that are at play in a historical event. To do so, I collected and triangulated data 
on the conflict from English language publications, contemporaneous news articles, as well as thirty-five in-person interviews. I conducted the latter in Khartoum, London, New York City and Ottawa in 2007 and 2008, with ethics approval from Carleton University (see Annexes 1, 2 and 3). The participants I interviewed represented all major groups that influenced and/or witnessed the decision-making process that led SLA leaders to choose when and how they rebelled. Conducting research on a sensitive issue relating to an ongoing conflict meant the qualitative data I was able to collect is limited in quantity and quality; my findings are therefore fragile. Nevertheless, it is possible to draw plausible inferences about the behaviour of the rebel groups based on this information.

\section{Policy relevance of the research}

The government of Sudan responded to the 2003 rebellion in Darfur with genocidal retaliation, creating an alarming humanitarian crisis. By 1 October 2008, the United Nations Office for the Coordination of Humanitarian Affairs (OCHA) estimated that as a result of the conflict, 2.68 million Darfuris were Internally Displaced Persons (IDPs) (or one third of Darfur's total population) (OCHA 2008); 240,000 refugees had fled to Chad (UNHCR 2008); and an additional 2.12 million people were "war affected", i.e. they had no means to support themselves but were not displaced (OCHA 2008). ${ }^{5}$ Furthermore, hundreds of villages have been destroyed (US State Department 2004); and sexual and gender-based violence against women and girls has been pervasive (UNFPA 2004). The Centre for Research on the Epidemiology of Disaster, the United Nations and most

\footnotetext{
${ }^{5}$ See United Nations Disaster Assessment Coordination Field Handbook (2000), for guidelines on OCHA's methodology.
} 
humanitarian organizations estimate that 300,000 people have died as a result of the conflict (CRED 2008). ${ }^{6}$

The international community's response to the crises has been massive, complex and costly, albeit arguably poorly coordinated and inefficient. A complex array of political, security and humanitarian efforts have been deployed by states, non-governmental organizations (NGOs), international organizations since early 2004, at which time the conflict had raged for almost one year. ${ }^{7}$ International spending on the conflict has been substantial, although notoriously difficult to disaggregate. The humanitarian operation, coordinated by OCHA, is the largest in the world. Its activities are dictated by the United Nations Work Plans ${ }^{8}$ (2005-2008) and the Common Humanitarian Fund ${ }^{9}$ (2007-2008), which have received a total of US\$ 3.16 billion for Darfur since $2005 .^{10}$ International spending on security operations is also massive: the total cost of the African Union/United Nations Hybrid Operation in Darfur (UNAMID) amounts to US\$2.84

\footnotetext{
${ }^{6}$ A 2004 World Health Organization (WHO) retrospective mortality survey estimated mortality among the displaced and war affected populations at 10,000 dead per month between June and August 2004. The survey used a retrospective approach based on a two-stage cluster sampling. The sampling frame included IDP settlements identified by the World Food Program or OCHA (in both government and non-government held areas). 50 clusters were randomly selected within the IDP settlements in each state (North, West and South Darfur). The second sampling stage used data collected anonymously by teams of interviewers using a structured pre-piloted questionnaire in Arabic. This data led the UN to estimate total conflict related deaths to be 200,000 during 2003-2005 (CRED 2008). The CRED estimates total conflict mortality during 2006-2008 to be 100,000 based on 92 mortality surveys conducted in Darfur between April 2004 and November 2007. The sum of these numbers gives 300,000 dead as a result of this conflict (2003-end 2007). ${ }^{7}$ For a discussion of international action in Darfur see Hamilton and Hazlett (2007), Black and Williams (2008).

${ }^{8}$ The Work Plan is an integrated relief, recovery and development action plan for Sudan. It coordinates the work of UN humanitarian agencies and international non-governmental organizations in Sudan. The funding data is drawn from the Assistance Database for Sudan (ADS), a database developed and maintained by OCHA: http://workplan.unsudanig.org/rts/index.php.

${ }^{9}$ The Common Humanitarian Fund (CHF) is a funding mechanism that distributes donor contributions to the Work Plan in order to give the Humanitarian Coordinator greater ability to target funds to the most critical needs, encourage early donor contributions and allow rapid response to unforeseen needs. Most donors still give to specific programs in the Sudan Work Plan (Resource Tracking Service, OCHA Sudan, http://workplan.unsudanig.org/rts/index.php).

${ }_{10}$ This does not include humanitarian funding for 2003 or 2004, for which I was unable to find disaggregated data for Darfur, nor does it include funding for international security operations.
} 
billion (2007-2009) (DPKO 2008). ${ }^{11}$ The Canadian government alone has pledged CAN\$275 million to be spent on security, diplomacy and humanitarian assistance to Sudan in $2008-2009,{ }^{12}$ which builds on the $\$ 388$ million Canada has provided since January 2006 (DFAIT 2008). ${ }^{13}$ Arguably, the crisis has monopolized a disproportionate fraction of international capital and political will available for humanitarian crises the world over and has overshadowed equally dire crises in the eastern region of the Democratic Republic of the Congo, northern Uganda, and Columbia (Hackett 2006).

The hypothesis being tested infers that the genocidal violence that has shaken Darfur would not have occurred were it not for the international community's humanitarian policies and actions. A close examination of the decision-making process that led the Darfuri rebel leaders to choose conflict in conditions in which success appears to have been unlikely is a useful enterprise in order to avert such crises in the future and devise appropriate international reactions to situations of this nature. This inquiry will not, however, provide a comprehensive answer to why conflict occurred in Darfur.

\section{Main arguments/findings}

This paper tests the explanatory power of one compelling hypothesis explaining why SLA leaders launched a rebellion in sub-optimal conditions in early 2003. My research engages with the work of Belloni (2006), Johnston (2007) and Kuperman (2008a, $2008 \mathrm{~b}),{ }^{14}$ who do acknowledge the puzzle and argue that the moral hazard of

\footnotetext{
${ }^{11}$ I was unable to find the firm numbers for the total cost of the African Union Mission in Sudan (AMIS, 2004-2007); estimate is US\$1.13 billion (Boshoff 2005)

${ }_{12}$ This number does not disaggregate Canada's specific contribution to Darfur-related assistance; it includes Canada's assessed contributions to UNAMID (DFAIT 2008).

${ }^{13}$ This number does not disaggregate Canada's contribution to Darfur-specific assistance, and refers to voluntary contributions (not assessed contributions to the UN) (DFAIT 2008).

${ }^{14}$ Johnston (2007) and Kuperman (2008a, 2008b) published after I undertook this research project.
} 
humanitarian intervention was explains the onset of conflict in Darfur. The evidence I have gathered paints two pictures which initially appear to conflict. On the one hand, the rebels demonstrated an awareness of the norm of international humanitarian intervention. In addition, evidence suggests they believed international intervention would benefit their struggle and sought such intervention ahead of the rebellion. These factors suggest the presence of moral hazard. On the other hand, information on the SLA's strategic vision and their anticipation of the government's reaction to the rebellion suggest the rebel leaders believed they could achieve military victory on their own. This evidence suggests the rebellion was not suicidal, nor were the rebels relying on international intervention to enable victory.

After closer examination, these two storylines present a nuanced and coherent understanding of a complex situation. While the vigorous international involvement in the north-south peace negotiations (in 2002) appears to have led the SLA leaders to believe the international community would send humanitarian assistance to alleviate suffering in Darfur, deter massive state-sponsored retaliation and led them to request the United Nations to sponsor a negotiations framework, the rebels appear to have recognized that international pressure would not enable them to extract political concessions from the government of Sudan. Only military strength would enable them to achieve their objectives of greater wealth and security for Darfur. The information gathered also indicates that, while others would have foreseen the government's retaliation against civilians, the SLA leaders did not and, thus, instigated rebellion without the ability to protect civilians. The limited evidence presented in this research therefore suggests the SLA leaders' behaviour was not fraudulent: they did not intentionally provoke a humanitarian catastrophe to advance their political objectives. In addition, the rebel 
leaders behaviour does not appear to be best described by Kuperman's "irresponsible" hypothesis, as evidence suggests the SLA's decision to attack the government when they did not hinge on the expectation that the international community would act as a safetynet.

The SLA's strategic vision and behavior appear to be consistent with the "foco theory" of rebellion, which may explain why the rebels believed they could achieve victory in such sub-optimal circumstances. The "foco theory" contends that guerrilla forces need not wait for ideal conditions to launch a successful insurgency against a militarily superior state (Childs 1995; Johnson 2006). Rather, initiating violence can induce the conditions necessary for victory. The justice of the rebel cause is believed to be enough to entice marginalized individuals to join the rebellion once its objectives are known; the most effective form of rebel propaganda is successful military action (Desai and Eckstein 1990, 464). Available information on the SLA's behaviour and strategic vision suggests they believed a string of stunning military victories would capture the attention and support of most Darfuris and enable rebel military victory against the government. Tentative evidence also suggests the SLA leaders had read the work of Ernesto "Che" Gevara, the father of the foco theory, as well as other revolutionary authors. These ideas, compounded with political and military inexperience, appear to have induced undue confidence in the young SLA leaders.

In addition, there appears to be a causal link between the timing of the rebellion and the north-south peace negotiations, which gained momentum in mid-2002. Yet the available information indicates that the occurrence of the negotiations is what led the rebels to initiate conflict at that time; the international involvement in these appears to be only one reason among many that contributed to the outbreak of violence. The 
negotiations reinforced the perception that violence was the only means to gaining political and economic concessions from the government. The SLA leaders may also have interpreted the Sudanese government's willingness to negotiate seriously with the south Sudanese rebels as a sign of its military weakness, and led them to assess that the military capabilities necessary to achieve victory were less than they would have been otherwise. The sum of these factors appears to have led the rebels to believe early 2003 was an opportune time to launch rebellion against the government.

\section{Overview}

In Chapter 2, I will provide a brief overview of the context in which the SLA chose conflict in order to situate the puzzle and set-up the research question. Chapter 3 spellsout the methodological framework used to conduct this research. Chapter 4 provides a detailed account of Kuperman's theoretical framework of the moral hazard of humanitarian intervention. In Chapter 5, I will operationalize the research by formulating the question, detailing how it will be tested, and testing the hypothesis with the obtainable information. I will provide a detailed account of the evidence which supports the hypothesis, as well as that which undermines it. I will end the chapter with an analysis of the findings. I then conclude and explore the policy implications of this research. 


\section{CHAPTER 2: SETTING UP THE PUZZLE:}

\section{Introduction}

Before undertaking a detailed analysis of the decision-making process that led the SLA leaders to instigate conflict against the government in early 2003, it is necessary to understand the context in which the Darfuri rebels made this decision. After a brief overview of the political and security dynamics that characterise Sudan and Darfur, I will review the onset of the conflict, focussing on its main actors, their objectives, capabilities and the challenges they faced to achieving these objectives.

\section{An overview of Sudan}

A brief overview of the political, religious and ethnic features of Sudan, with a focus on the unequal regional and ethnic distribution of power, will provide some context for the rebellion. The Republic of the Sudan (Sudan) is located in the Horn of Africa and borders ten countries. Sudan is the largest country in Africa, with a total estimated population of 37 million, and placed 147 of 177 countries on the 2007/2008 United Nations Human Development Index (UNDP 2008). The capital, Khartoum, is located along the Nile in northern Sudan. The city and its surrounding areas are stable and prosperous. Conversely, the east, south and western regions of Sudan - the peripheries are, to varying degrees, marginalized from power, economically underdeveloped, and conflict-ridden. 


\subsection{Economic relations between the centre and the peripheries}

Sudan is a classic case of Herbst's African state (2000). He argues that low population density and difficult terrain in many African countries mean central governments gain little from investing in infrastructure, economic development and holding the monopoly of violence outside of the central region (the capital). This distorted incentive structure can explain, in part, the dysfunctional nature of the Sudanese state. Three tribes from the Khartoum area have had highly disproportionate access to Sudan's power and resources since independence from Britain in 1956. They have directed these almost exclusively toward economic development in Khartoum and toward the military (Cobham 2005, 465). Nevertheless, elites from the north, east and west (although not the south) have integrated to some degree into academic, religious and political circles in Khartoum (Salih 2005, 7).

\subsection{Ethnic and religious identities}

Ethnic and religious identities have also had an impact on interregional relations in Sudan, and they have motivated the use of violence to gain social, political and religious self-determination. The northerners (including Khartoum) live mainly near the Nile in northern Sudan; they consist of Arab and Nubian groups. They are Muslim, speak Arabic and follow Arab cultural patterns. The second group consists of African tribes who emigrated from West Africa over the past six hundred years. They inhabit parts of western and eastern Sudan. They are also Muslim and work mostly as farmers and agricultural laborers. The third group is the southerners, consisting of Nilotic and Sudanic peoples. They are Christian and animist, practice shifting cultivation or are pastoralists and they speak Nilotic languages. 


\subsection{The political context}

Current President General Omar al-Bashir and the ruling National Islamic Front came to power in 1989 in a bloodless coup that overthrew a democratically elected government. Bashir reinstated a military dictatorship, banned political opposition parties, increased the country's military capabilities and imposed Islamic law. Strongly backed by Islamic movements in Khartoum and abroad, the government's stated objective was to "Islamise the country" (Salih 2005,8 ). However, over the past twenty years, the dominant discourse in Khartoum has shifted from religious supremacy to ethnic supremacy, focusing now on the superiority of Arab ethnicity (in opposition to "African" ethnicity), rather than on the creation of an Islamic state and the subjugation of the southern Christians. "African" Muslims from the east and west have increasingly been targeted by discriminatory policies. While racism is not new to Sudan, the explicit terms of the government's new discourse marked a significant shift (De Waal 2007, 26).

\subsection{The government security apparatus}

The Sudanese Armed Forces are well equipped by African standards: the Sudanese Army is approximately 110,000-strong and equipped with heavy weaponry. Its Air Force counts 36 combat aircraft (EIU 2009; ICG 2002a, 117). In addition, when Bashir took power, he initiated the People's Defence Force (PDF), part of a quest to have "one million men capable of bearing arms" (Saeed 1995). The force is trained and armed by the Sudanese military and is reported to be three times its size (Human Rights Watch 1999). The government has also "subcontracted" counterinsurgencies by establishing loose contractual agreements with

proxy militias through the auspices of the PDF (Salih 2005). These militias are 
recruited on the cheap: in return for a horse, a gun, unlimited loot, and land, they are tasked with attacking the civilian support bases of rebel movements (Burr and Collins 2007, 288). These forces respond to their own incentive structures and answer in varying degrees to state command. They are predominantly Arab.

\subsection{The rebel movements}

Since independence, rebel movements in each peripheral region have fought the Sudanese government for more of Khartoum's power and resources. In Darfur, prior to 2003, a loose movement acted under the banner of the secessionist Darfur Liberation Front; the Beja Congress, and then the Eastern Front took up arms in the eastern region of the country; in the Nuba Mountains (south Kordofan) and the Blue Nile region, rebel forces too engaged the government. While these conflicts remained low-intensity, the war between the north and south was of much more significant proportions. Lasting for most of the post-independence era, this war was fought over control of resources ${ }^{15}$ as well as for political and cultural self-determination.

\subsection{The north-south conflict}

War raged between north and south Sudan from 1955 until the Addis Ababa Peace was signed in 1972. After a hiatus of only 11 years, the south Sudanese again took up arms against the government under the leadership of Dr. John Garang and the Sudan People's Liberation Army/Movement (SPLA). The war was Africa's longest by the time it ended in 2005. An estimated two million people died of direct violence or related

\footnotetext{
${ }^{15}$ In particular, the significant oil fields discovered in the $1970 \mathrm{~s}$ on the border separating north and south Sudan; water was also a contentious issue as south Sudan controls the flow of the Nile (ICG 2002a)
} 
starvation and disease between 1983 and 1998 (USCRI 1998). ${ }^{16}$ Three to four million civilians were displaced, resulting in the largest displaced population in the world (USCRI 1999). The government fought the insurgency with its military, the Popular Defence Forces (PDF) and proxy militia forces (murahaleen). It used a deliberate strategy of targeting civilians to undermine the support and resource base of the rebels (ICG 2002a, 121-122). The PDF and associate proxy militias were responsible for most of the atrocities committed against civilians.

There were several initiatives to resolve the north-south conflict in the 1990 s and early 2000s, including the Inter-Governmental Authority on Development in Eastern Africa (IGAD) peace process, the Egyptian-Libyan Joint Initiative, a bilateral effort by Eritrea, a Nigerian initiative, as well as efforts by European states (ICG 2002a, 153-175). In 1999-2000, several factors shifted, enticing both sides to seriously consider a negotiated settlement: the parties had reached a military stalemate; power shifts within the government meant hard-line Islamists were sidelined; and growing government discomfort from diplomatic estrangement on the world stage (Kenny 2004). Most significantly though, subsequent to terrorist attacks on 11 September 2001, US President Bush renewed counter-terrorism cooperation with the government of Sudan. Simultaneously, his administration developed a policy of supporting a negotiated settlement of the north-south conflict, and in early 2002 put its diplomatic and economic weight behind the Inter-Governmental Authority on Development (IGAD) peace process (Punier 2005, 89; Flint and de Waal 2005, 31; ICG 2002a, 153-175).

\footnotetext{
${ }^{16}$ The most reliable source of mortality data for this conflict is a 1998 United States Committee for Refugees and Immigrants report which conducted a quantitative analysis of all resources on the conflict since it began (USCRI 1998). The figure has become a commonly accepted number in the absence of better data (ICG 2002a, 3).
} 


\subsection{The Naivasha Peace Process}

Peace gained real momentum in July 2002 when the government of Sudan and the SPLA signed the Machakos Protocol, which set a framework for a comprehensive resolution of the conflict. By doing so, the government demonstrated its willingness to make significant concessions to the south Sudanese. The event generated a fury of national media attention. ${ }^{17}$ Power and wealth-sharing negotiations took place in Naivasha, Kenya, under the aegis of the IGAD and diplomatic and economic pressure from Western governments. The US placed substantial pressure on both sides to make a deal, with promises of a "peace dividend" if an agreement was signed, and threats of severe penalties if it was not (Kenny 2004; ICG 2002a). In fact, Prunier writes that "Naivaisha [turned] into a strange theatre where the actors appeared driven to compromise more by American pressure than by any inner conviction that peace should actually be negotiated" $(2005,89)$. Peace between the north and the south was the international community's priority in Sudan, and they believed the Naivasha process was a unique and fragile window of opportunity for peace. International involvement in the north-south negotiations was clearly couched within the discourse on international humanitarian principles, notably the protection of civilians. Referring to the impact of the Naivasha talks on civilians in south Sudan, Jeff Millington, the American chargé d'affaires in Sudan in 2002, stated: "the fighting, killings [have] stopped. There have been no significant military engagements. Relief is going unimpeded throughout the south and other areas.

\footnotetext{
${ }^{17}$ LexisNexis Academic media database finds 93 documents for the following search: Source: Major World Publications; search terms: "BBC Monitoring: International Reports" and "Sudan" and "negotiation" and ("SPLA" or "SPLM"), date: (between) 1 April 2002 and 26 February 2003. The vast majority of the articles were published in Sudanese media.
} 
This is important" (Khartoum Monitor 2002). ${ }^{18}$

The Comprehensive Peace Agreement (CPA) was signed on 9 January 2005. "The CPA is a charter for the transformation of governance in Sudan," affirms Azzain Mohammed $(2007,204)$. It is a power and resource-sharing agreement that aims to bring about democratization, decentralization and a sound and fair system of national revenue sharing. The agreement explicitly includes the Blue Nile and Nuba Mountains regions whose rebels had allied with the SPLA, but is meant to address the grievances of rebel movements throughout the country.

\section{Darfur's place within Sudan}

Darfur is approximately the size of France and the total population in the three Darfur states is estimated at approximately 6 million (UNFPA and Government of Sudan 1999). Government investment in Darfur is marginal. A case in point is that, despite promises from successive governments (including military and democratically elected governments, as well as moderate and Islamic fundamentalist governments), a paved road has not yet been built linking Darfur and Khartoum (Respondent 9: personal interview, July 2007). The Black Book: Imbalance of Power and Wealth in Sudan, published anonymously in Khartoum in May 2000 by members of JEM, one of Darfur's rebel groups, gives a detailed breakdown of the distribution of power in Sudan, highlighting Darfur's marginalization and its devastating consequences on the human and economic development in the region. ${ }^{19}$

\footnotetext{
${ }^{18}$ See Chapter 4 for a discussion of the norm of international humanitarian intervention.

${ }^{19}$ Cobham (2005) verified the data used in the Black Book; the findings are also consistent with UNICEF's Multiple Indicator Cluster Survey (2000)
} 


\subsection{Darfur's ethnic groups}

Darfur is populated by two broad groups: "Arabs", who are generally pastoralists and have traditionally herded in the northern areas of Darfur, and "Africans", who are subsistence farmers and have planted in the more agriculturally fertile southern regions (Daly 2007, 6). No single group holds the monopoly of violence in Darfur, especially not the Sudanese state. Violent conflict over land and resources has therefore always existed between these two broad groups, as well as between various subgroups of each. Nevertheless, a form of socio-geographical order allowed nomads the customary right to pasture their animals in areas held by farmers (De Waal 2004, 720; Anderson 2004).

The traditional land tenure system posited that only farmers could receive land titles: nomadic tribes, therefore, did not officially own land in Darfur. Positions of power in the regional administration were exclusively distributed to land owners, implying that pastoralist Arab tribes could not occupy positions of power within the regional administration. However, this land tenure system and distribution of power only became problematic when land and water became scarce in the region (Abdul-Jalil 2006).

Over the past two decades, what was once a sufficient though sparse quantity of fertile land has been eroded by desertification and successive droughts in the mid-1980s (Abdul-Jalil 2006, 14). As a result, nomadic groups from the northern Darfuri semideserts have been pushed southward in their search for grazing land and water. This forced ecological migration led to increased competition over scarce resources, which was compounded by the fact that decreasing rainfall and falling productivity meant that farmers needed larger quantities of land (ICG 2004, 9). 


\subsection{The conflict spiral}

Increased demand for land created unprecedented inter-group dynamics and, ultimately, presented insurmountable challenges to the customary property rights regimes and traditional dispute resolution mechanisms of Darfur (ICG 2004, 10). Historical land use practices were ignored in favour of other mechanisms, notably armed conflict. Simultaneously, weapons at discount prices started pouring into the region from Libya (Burr and Collins 2005, 285). No state apparatus in Darfur was able to impose law and order; insecurity therefore became rampant as the cost of plunder decreased and the need for land and subsistence resources increased. Rising insecurity created more need for protection. A vicious spiral of militarization thus ensued throughout Darfur. General Ibrahim Suleiman, governor of North Darfur State from 2001 to 2003, stated in late 2004: "I saw that the situation was becoming very grave [in 2001-2002]. The violence was increasing; all the different tribes were gathering up weapons" (Anderson 2004). Anderson (2004) reports that Khartoum's failure to impose order was interpreted by the African tribes as a deliberate, provocative policy: they believed the raids against them were endorsed by the government.

\subsection{The conditions for mobilization}

Gurr (1970) suggests several factors propel ethno-cultural rebellion and political action. He argues that relative deprivation - the difference between perceived entitlements and actual well-being - is the key reason. In addition, he argues rebellions will only occur as a result of relative deprivation if there is both opportunity for success and the affected group is able to mobilize. Ability to mobilize depends on the salience of ethno-cultural identities and the physical capacity to engage in conflict. All of these 
conditions were present in Darfur prior to the instigation of rebellion, except reasonable chances of success.

The documented domination of the centre over the peripheries in Sudan is evidence of both the relative deprivation and ensuing frustration that existed among Darfuri elites (Cobham 2005). It is important to note that the focus of this research is on examining what propelled the rebel leaders - the elites - to choose conflict in early 2003 . The fact that ordinary Darfuri people may have been unaware of the interregional disparities that characterized Sudan is not relevant. What is important is that the Darfuri elites had access to Khartoum and were aware of, and discontent with, the unfair distribution of power at the centre.

In addition, the conditions for mobilization existed. Stewart (2003) argues that groups mobilize around group lines to satisfy economic aspirations based on the frustrations of inequality between them. The crystallization of Arab ethnic superiority in Khartoum created a dichotomy between Arab and non-Arab group identities, demonstrated by the hardening of political coalitions along ethnic lines in the late 1990s (Salih 2005, 20). There was, therefore, fodder for mobilization around salient ethnic identities within Darfuri elite circles. This mobilization would have naturally aligned itself with resentment within Darfur, as low-intensity violent conflict over increasingly scarce land and resources occurred predominantly along ethnic lines.

The second condition for mobilization is the capacity to fight. Competition for resources and the disintegration of traditional property rights mechanisms coupled with the inexpensive access to arms from Libya led to the militarization of Darfur. Selfdefence militias had sprung up along ethnic and tribal lines. Furthermore, because of Sudan's tense relations with Chad and Eritrea, the latter harboured and funded the Darfuri 
rebels. The cost of armed rebellion was therefore low for the Darfuri elites.

Gurr also proposes that the existence of alternatives is important: whether the disgruntled parties had access to other means of achieving their political goals. In the case of Darfur, few alternatives are apparent, given the historical disproportionate marginalization from power of Darfuris demonstrated in the Black Book (Cobham 2005).

Disenchanted Darfuris had few if any options for taking an effective political stand. Little opportunity existed for political activism [...]. One course of action was to stay politically aloof - tantamount to withdrawal from any political engagement, surrendering the political sphere to the centrist groups. A second was to take up arms. (Kamal el-Din 2007, 108)

The rebels, therefore, appear to have had good reason to have wanted to instigate rebellion in Darfur.

\section{The rebellion}

In early 2003, seven months after the Machakos Protocol was signed by the SPLA and the government of Sudan under pressure from Western governments, two Darfuri rebel movements cooperatively launched a political rebellion. The first and most important, the Sudan Liberation Army/Movement (SLA), was initially called the Darfur Liberation Front. It was borne of the initiative of Darfuri student activists in their late twenties and early thirties who were disfranchised with the marginalization of Darfur (Kamal el-Din 2007, 102). The young men decided in the mid-1990s, while at the University of Khartoum, that violent conflict was the best means of achieving their political objectives (Flint 2007, 143; Burr and Collins 2007, 289). The most renowned of these was Abdelwahid Mohammed al-Nur, who officially came to the helm of the movement in 2002. Based in the Jabel Marra mountain range, home of the Fur, the movement's fighters hailed from the self-defence militias that had sprung up along tribal 
lines as insecurity rose in the region in the lead-up to the rebellion (Flint and De Waal 2005, 74). The leaders kept a wary distance from the tribal leadership in Darfur and from the Darfuri intellectual and political elite, both groups having expressed either reservation toward the rebellion or a willingness to co-opt it. The movement was an expression of widespread frustration with underdevelopment, insecurity and government neglect in the region.

The second rebel group, the Justice and Equality Movement (JEM), has different origins. JEM was created by Darfuri Islamist intellectuals with close ties to the ruling National Islamic Front. Many had become disillusioned with the Islamist government's inability and unwillingness to deliver on promises of equity and prosperity. They consequently broke ranks with the government in the mid-1990s and secretly authored the Black Book in 2000. In June 2002, they began amassing military forces that hailed almost exclusively from the Kobe sub-group of the Zaghawa tribe, which straddles the DarfurChad border (Flint 2007, 150-151). JEM's political structure was solid and its political demands eloquent and mature, yet its military capabilities at the onset of the conflict were marginal.

Details of the rebels' military capabilities at the onset of the conflict are scarce. Jane's Intelligence Review (2008) provides some information, which was corroborated by a "restricted" report to which I had access through a respondent, as well as in-person interviews with two respondents who fought with the SLA in 2003 (Bashura Hassan elTaher and Respondent 21: personal interviews, August 2007) and a senior SPLA leader (Edward Leno: personal interview, August 2007). ${ }^{20}$ Most SLA military equipment was stolen from government positions in Darfur. Weapons were primarily small arms and

\footnotetext{
${ }^{20}$ The literature referenced throughout this research also corroborates most of these claims.
} 
light weapons, including AK-47 rifles and rocket-propelled grenade launchers. Mobility was the critical factor: the SLA forces operated in highly mobile small units, using horses, camels and light vehicles; modified four-wheel-drive vehicles ("technicals") were the most prized asset of a commander. Funds appear to have been sourced from local, national and diaspora supporters of the rebellion; the governments (or certain wings thereof) of Eritrea, Chad and Libya have allegedly intermittently harbored and/or supported the SLA. The rebel movement also received some limited material support from the SLPA, notably one satellite telephone and military coaching.

When comparing the two rebel movements, the consensus among Darfuris, Sudanese and international experts is that the SLA was the "heart of the insurgency" at the beginning of the conflict: it was a larger, more effective military force than JEM and had broader and more entrenched support within the local population (Flint 2007, 153; Tanner $2005,21)$. For these reasons, and given the limited scope of this research, I have chosen to focus exclusively on the SLA's actions at the onset of the conflict.

\subsection{The timeline of the conflict}

A brief timeline of the conflict will set the stage for an intriguing puzzle. The first successful SLA attack targeted the town of Golo, in the Jabel Marra, in June 2002 (Tanner and Tubiana 2007, 19). The rebels exclusively hit government installations (the police station and military barracks): they did not target Arab militias or civilians. At this time, the movement was very under-equipped, with less than a handful of vehicles, no satellite telephones and meager arms (Bashura Hassan el-Taher: personal interview, 
August 2007). The objective of this and other attacks during the fall of 2002 was to capture military equipment and food for their forces.

In December and January 2002/2003, the Darfur Liberation Front leadership contacted Dr. John Garang and the Sudan People's Liberation Army/Movement. They cooperatively drafted the movement's political declaration, which would be released a few months later. Dr. Garang reminded the young rebels that they must fight the government before they would be granted any concessions from it (Flint and de Waal $2005,82)$.

It is in early 2003 that the SLA and JEM formally instigated full-scale rebellion against the government. They launched a first major and highly successful attack in February against the town of Golo (Burr and Collins 2007, 288), this time with 300 men supported by thirty "technicals" (land-rovers with mounted machine-guns); they killed close to 200 soldiers and forced the garrison to flee. In March 2003, the SLA publicized its political platform (SLA/M 2003). The strike that propelled the conflict onto the national and international agendas occurred in the early hours of 25 April 2003, when both rebel groups attacked el-Fashir airport. They destroyed five planes, two helicopters, killed 75 troops and captured General Ibrahim Bushra, the garrison commander (Flint and de Waal 2005, 99-101). This was a stunning, seemingly provocative attack that generated national and international media attention. The SLA capitalized on the attack to publicize their objectives and call on all Darfuris to support them. Their publicity efforts paid off: people across Darfur joined the rebellion and soldiers defected to the rebel movements in droves. 


\subsection{The government's response to rebel attacks}

The governments' initial response to the brewing rebellion was weak and unfocussed (late 2002 and early 2003). Preliminary communication between the rebels and the government in late 2002 revealed that the rebels did not have clear political objectives. Without significant military capabilities or political demands, the government did not perceive the brewing rebellion to be a serious problem. Concurrently, it publicly threatened the insurgents with disaster should they rebel, dismissed the rebellion as "ethnic conflict", undertook nominal efforts to negotiate/bribe the rebels, and targeted the rebel forces with the army and Air Force. These half-hearted efforts proved unsuccessful though (Prunier 2005, 100).

The provocative nature of the attack on the el-Fashir airport (25 April 2003) signalled to the government that they had a problem on their hands. They decided to eliminate the rebels militarily by delegating the counter-insurgency to proxy militia, called the Janjaweed. These militias are very similar in nature to the murahaleen in southern Sudan: they were initially loosely organized ethnic Arab militias that were recruited, organized, armed and trained by the government (de Waal 2004; ICG 2004, 1; Prendergast and Stroehlein 2004; Flint and de Waal 2005, 33-65; Haggar 2007). In return for loot, land and military equipment, and in cooperation with the Sudanese Air Force, these groups unleashed massive violence against civilians believed to be supporting the rebellion. Given the scarcity of land and the traditional inability of pastoralist tribes to own land, these individuals hailing from pastoralist communities were motivated by the government's promises.

Rebels victories continued into the summer of 2003, but by September the government had deployed its forces. Fur, Zaghawa and Masalit villages were hit hardest 
(ICG 2004, 16). Deaths attributed to violence, disease, and malnutrition caused by the conflict were greatest between September 2003 and April 2004 (Guha-Sapir and Degomme 2005, 36). ${ }^{21}$ On 5 December 2003, the then United Nations UndersecretaryGeneral for Humanitarian Affairs and Emergency Relief Coordinator, Jan Egeland, labelled Darfur the worst humanitarian situation in the world (UN News Service 2003). By August 2004, more than 405 villages in Darfur had been completely destroyed, with an additional 123 substantially damaged (US State Department 2004); ${ }^{22} 170,000$ persons had fled to eastern Chad; and there were over 1.2 million IDPs in western Sudan (OCHA 2004). Of all the attacks in Darfur between January 2001 and December 2005 registered by Petersen and Tullin (2006), the government and its allies were responsible for 97 percent. ${ }^{23}$ The government of Sudan was formally accused of these crimes when the International Criminal Court issued arrest warrants for Cabinet Minister Ahmad Muhammad Harun and alleged Janjaweed leader Ali Muhammad Ali Abd-al-Kahman ("Ali Kushayb") on 27 April 2007 and for Sudanese President Omar el-Bashir on 4 March 2009; all charges are for war crimes and crimes against humanity against the people of Darfur.

\footnotetext{
${ }^{21}$ Based on the application of "low" and "high" Crude Mortality Rates monthly estimates to UN population figures for each region in Darfur (North, West and South) (Guha-Sapir and Degomme 2005, 36). Petersen and Tullin (2006) also report that 69 percent of all attacks in Darfur (between January 2001 and December 2005) took place between April 2003 and late March 2004. The latter is based on testimonies and reports of attacks on villages in Darfur gathered from media, human rights and United Nations sources. The search produced a sample of 178 detailed accounts covering attacks on 372 villages during the period January 2001 to September 2005.

${ }^{22}$ The US State Department Atrocities Documentation Team conducted a random-sample survey of Darfurian refugees in eastern Chad in July and August 2004. The team interviewed 1,136 refugees.

${ }^{23}$ The remaining 3 percent were attributed to the rebels. See footnote 21 for basis of this assessment.
} 


\section{The puzzle: Sub-optimal conditions}

While conditions for mobilization existed, the SLA launched rebellion in circumstances in which success appears to have been highly unlikely and at great risk to themselves and their civilian support base.

The SLA's objectives were ambitious, multiple and rather vague. Their political declaration released on 14 March 2003 reads: "the objective of SLM/A is to create a united democratic Sudan on a new basis of equality, complete restructuring and devolution of power, even development, cultural and political pluralism and moral and material prosperity for all Sudanese" (SLA/M 2003, 2). As described above, the SLA leadership grew out of frustrations around the distribution of power and wealth in Sudan. Mobilization for the movements was possible due to local frustrations cause by insecurity in the region. The rebel movements' objectives were therefore to bring security and prosperity to Darfur; they believed reforming the political structures of Sudan would accomplish these.

To achieve these ambitious objectives, the rebels had to either overthrow the government in power, or credibly threaten its ability to govern. De Waal (2007) compellingly argues that instability at the periphery has little to no impact on stability at the center in Sudan. Only a threat to the center would enable Darfuris to extract their demands from the government at the negotiating table. Since 2003, nearly 70 percent of the country's annual revenue has been generated from oil exports (Heuty and Carlitz 2009). The oil fields are situated on the north-south border, which were subject to armed dispute between the government and the SPLA, and the refineries are on the Red Sea coast. Both of the latter, as well as Khartoum, were over a thousand kilometres away from the Jabel Marra of Darfur (rebel base). Therefore, achieving the rebels' political 
objectives required substantial military capabilities. In addition, attacking the government in Darfur, where the government has no strategic interests, would seem an unlikely means of extracting power and resources from Khartoum.

Yet at the onset of the conflict, the rebel forces were significantly militarily inferior to the combined capabilities of the government. Guerrilla warfare is typically asymmetrical: it pits irregular forces organized in small, highly mobile units without heavy machinery against traditional militaries (Weinstein 2007, 29). That said, the balance of accumulated capabilities between the Darfuri rebel forces and the state appears to have been grossly unequal. As detailed above, the Sudanese formal military and intelligence apparatus is fierce. In addition, the Janjaweed were estimated to number approximately 20,000 (EIU 2009). On the other hand, the rebels were, by all accounts, under-manned, underequipped and under-funded in comparison (Jane's Intelligence Review 2009; Daly 2007, 4). Despite some efforts, they did not secure a military alliance with key armed actors in Darfur, notably the Arab tribes. In addition, the rebels were inexperienced in political negotiation, whereas the government of Sudan was highly skilled in this area.

Finally, the government's response to the rebellion appears to have been predictable. Weinstein writes that "counterinsurgent armies are notoriously brutal, employing tactics that target civilians indiscriminately in an effort to dry up the support base for guerrilla movements" $(2007,37)$. There was clear precedent for the targeting of civilians in Sudan: the government of Sudan had used ethnic militias to fight the Sudan People's Liberation Army in south Sudan (Flint and de Waal 2005, 106; ICG 2002a, 115-120). Lastly, as detailed in Chapter 1, the government clearly warned the Darfuris not to follow the path of south Sudan (Flint and de Waal 2005; Prunier 2005, 91). 


\section{The question}

The SLA leaders appear to have intentionally launched a rebellion in early 2003 against the government of Sudan, thereby dictating the timing of the conflict. Their political and military objectives were great; their foe was militarily and politically superior, had used genocidal violence against the south Sudanese and threatened the Darfuris should they rebel. It is reasonable to assume that the rebel leaders who made the decision to rebel were aware of these factors at the time of their decision. This puzzle raises the question: why did the SLA rebel leaders choose to rebel in conditions that were grossly unfavourable to their success, at great risk to themselves and their civilian support base?

At issue is the decision-making process that led the SLA leaders to make such a seemingly high-risk decision. Understanding the structural incentives that shaped this process, as well as the strategic intentions of the SLA leaders at the onset of the conflict will help answer this question. The analysis assumes that the agency of the rebel leaders was a significant contributing factor to the occurrence and timing of the rebellion in Darfur.

\section{Situating the question within the literature on Sudan}

Several English-language books of note have been published on the origins and anatomy of this conflict. The most important of these include Darfur: A Short History of a Long War (2005, 2008), co-authored by Flint and de Waal, which details the origins, motivations and actions of the conflicts' actors. Prunier's Darfur: The Ambiguous Genocide (2005) provides a history of the marginalization of Darfur and a detailed analysis of its impact on the conflict's actors, as well as the international community's 
reaction to the crisis. Burr and Collins published Darfur: the Long Road to Disaster in 2006, which describes the long and complex relationship between Libya, Chad and Sudan, and the impacts of the latter on the political and security contexts in Darfur. Daly's Darfur's Sorrow: a History of Destruction and Genocide (2007) provides a thorough history of Darfur and its peoples, with a focus on the Fur tribe. War in Darfur (2007), edited by de Waal, is a collection of essays by Sudanese and international authors on numerous facets of the conflict. The International Crisis Group, Amnesty International and the Small Arms Survey have also published exceptionally good reports on the crisis.

Within this body of literature, comparatively little energy has been devoted to a detailed analysis of the rebel movements. Of the above-mentioned authors, Flint (2005, 2007) has dedicated the most attention to the subject. Tanner and Tubiana (2007) also provide a strong account of the rebel movements' origins and a meticulous chronology of the conflict.

The timing of the rebellion has also garnered little scholarly interest. This appears to be primarily due to the abundance of evidence demonstrating the conditions for mobilization in Darfur. Scholars have, therefore, not questioned the occurrence of the rebellion - why Darfuri rebel leaders chose to rebel - nor have they devoted much energy to investigating why it happened when it did. An explanation of the timing of the rebellion must account for why the rebellion (dependent variable " $y$ ") did not take place before the presence of " $x$ " (independent variable), and how the presence of " $x$ " explains the occurrence of this specific type of rebellion (" $y$ ", as opposed to rebellion " $z$ "). In relation to the latter criterion, at the onset of the conflict the Darfuris arguably had three options: to not rebel; to attack the Arab militias (" $z$ "); or to attack the government of Sudan ("y"). 
The factors most commonly identified to explain the timing of the rebellion in Darfur are: a rise in insecurity fuelled by Arab militia attacks on African tribes and tribal assets; the emergence of a rebel leadership; and Hassan al-Turabi's support for JEM. While evidence detailed below supports these explanations, they do not compellingly explain why the rebels attacked government installations in Darfur in 2003 given the sub-optimal conditions and threat of retaliation.

\section{1 "No other choice"/frustration with the status quo}

Flint and de Waal (2005) argue that the timing of the rebellion was dictated by rising insecurity in Darfur. The crux of their argument is that the rebels believed they had no other choice but to rebel when they did: the threat to themselves, their civilian support base and their tribal assets was so great that the rebellion was an act of self-defence. The argument assumes that rebellion did not occur before because insecurity was "not bad enough". The authors referenced above document rising insecurity in the region. Tubiana writes: "one of the more striking early signs of the conflict was a dramatic increase in violent incidents between farmers and herders" (2007, 70). Evidence of the long-term environmental degradation of the region, the increasing scarcity of resources (HomerDixon 2007) and the proliferation of small-arms (Idriss 2000) explains why insecurity was rising. Furthermore, not only was inter-tribal warfare rising, with a notable increase in attacks by Arab militias against African farming tribes (Tanner and Tubiana 2007, 14), as detailed above, the government was indifferent to the situation and, in some instances, a sponsor of violence (Flint and de Waal 2005, 64). This led many victims to believe the government condoned the violence. The rebels believed they had no choice but to take action to protect their people. At the same time, the rebellion was an expression of 
Darfuris' exasperation with government indifference to the plight of the region. The first thesis contends to explain the timing of the rebellion while the second its occurrence.

While this binary argument is persuasive, it does not appear to fully explain why the rebels attacked the government in sub-optimal conditions. If the rebels' objective was to protect civilians from harm, then attacking in sub-optimal conditions is rational for reasons of self-defence. Yet attacks would have been best directed against the source of the threat - the Arab militias - whereas the rebel movements exclusively targeted government installations. In fact, doing so undermined the self-defence objective by provoking the military, which was not a source of insecurity prior to the attacks. On the other hand, if the rebellion's objectives were political, attacking the government is rational, but not in conditions in which success appeared unlikely and retaliation against civilians likely.

\subsection{The emergence of rebel leadership}

A second argument explaining the timing of the rebellion is the emergence of a rebel leadership in the region. It assumes that rebellion in Darfur would happen as soon as young men capable of leadership were able to organize. De Waal states:

Given the structural turbulence of the Sudanese polity, perhaps the only surprise is that Darfur did not plunge into outright war earlier on. That escape was probably due to a sequence of events that left Darfur without the leadership needed for coordinated insurrection. $(2007,35)$

The claim is primarily tied to the government's elimination of Darfuri rebel leaders after the failure of Daud Bolad's rebellion in 1991. Bolad launched a revolt in Darfur for reasons similar to those enumerated by the SLA (Prunier 2005, 73-74; Flint 2007, $142-$ 143). He was a Fur member of the Islamic Brotherhood and involved in the National 
Islamic Front when it came to power in 1989. He soon broke ranks over the marginalization of Darfur from the power structures in Khartoum and joined the SPLA. In late 1991, he and a small group of SPLA fighters launched attacks against government installations in Darfur in the hopes of spurring a rebellion. He lacked equipment, troops and the ability to communicate to Darfuris, and was soon overtaken by government forces and local tribal militias. The government captured and tortured Bolad and his associates to death, which is argued to have deterred revolution in Darfur for a generation. The young SLA leaders would, therefore, be the first young men thirsty for rebellion to come of age since that time.

Kamel el-Din makes a similar argument. He contends that the government of Sudan intentionally manipulated inter-tribal relations in the region in order to prevent the tribal collaboration necessary to launch a political rebellion against the government:

For most of the years since Sudan's independence in 1956, local skirmishes have had the effect of confusing any unifying spirit in Darfur [...]. Without such local differences which the government covertly exploited [...], the region could have exploded in rebellion far earlier than it actually did $(2007,93)$.

While there is support for the claim that rebellion could not have occurred before the existence of revolutionary leadership in Darfur, the emergence of a rebel leadership does not de facto explain rebellion in such risky conditions.

\subsection{Involvement of Hassan al-Turabi}

Prunier (2005) argues that Hassan al-Turabi played a central role in the occurrence and timing of the conflict in Darfur. Turabi is known as the Sudanese Islamist revolution's "Guide" and was involved in every Sudanese uprising since the 1964 
overthrow of Brigadier-General Ibrahim Abboud. Highly educated, ${ }^{24}$ he is a brilliant and engaged intellectual, and a politically savvy, pragmatic and authoritarian leader. He was the preeminent figure in the 1989 coup that brought the Islamists to power and controlled the direction of the Sudanese state until, on 12 December 1999, President Bashir exacted a "coup" by forcing Turabi to resign from his position as President of the Parliament and placed him under house-arrest. Prunier (2005) presents evidence that Turabi then turned to exploit the low-level turmoil in Darfur in order to regain national power. $\mathrm{He}$ immediately founded the Popular Congress Party (PCP), a national political party, and is alleged to have co-opted the Darfuri rebel movement JEM as its military wing (Prunier 2005, 81-88). Kamal el-Din asserts that many in Khartoum believed the revolt in Darfur was the direct work of Turabi and his associates, intent on revenge for their political ousting $(2007,108$; Salih 2005, 16). This argument therefore assumes that JEM was the catalyst for rebellion in Darfur.

Several authors have argued against this claim on two counts: Turabi was not directly responsible for the creation of JEM, contends Kamal el-Din (2007); others argue that JEM was not a catalyst for the insurrection in Darfur. Evidence presented by Flint (2007) and others demonstrates that JEM was created in the mid-1990s and became critical of the Islamist government well before Turabi was kicked out of office. When Turabi did set up the PCP, few JEM leaders joined the organization (Kamal el-Din 2007, 108). In addition, JEM's political positions have differed on several occasions from those of the Turabi/PCP (Kamal el-Din 2007, 105). Finally, Kamal el-Din argues that the suppressive circumstances under which the PCP existed would not have allowed it to channel

\footnotetext{
${ }^{24}$ He completed a Master of Law at the London School of Economics and a Doctorate of Law at the Sorbonne.
} 
significant material support to the rebel movements. "The government and its security organs were effective in freezing or confiscating most of the assets of PCP members, often using illegal means" (Kamal el-Din 2007, 109). On the second point, evidence suggests JEM was not the catalyst of rebellion in Darfur, but was rather a supporting actor. While JEM did have a strong political foundation (Flint and de Waal 2005, 92-95), as detailed previously, they were militarily inferior to the SLA, did not have a wide net of popular and/or tribal support and were, therefore, not significant enough to dictate the timing of the rebellion (Tanner 2005, 21; Flint and de Waal 2005, 153; Abdalla Adam Khatir: personal interview, July 2003). Therefore, as I have argued above, compelling evidence suggests that JEM was not the catalyst for rebellion in Darfur, nor was the conflict a result of Hassan al-Turabi's machinations.

\section{Conclusion}

Three concurrent trends are visible in Sudan in 2002-2003: a negotiated resolution of Africa's longest civil war became an actual possibility; the international community became heavily involved in this negotiation process, applying pressure on the government to address the demands of the south Sudanese; and full-scale rebellion broke out in Darfur, a province with long-standing grievances. While Darfuris would have wanted to rebel, their choice to launch armed rebellion against the government in conditions in which success was unlikely and retaliation likely seems puzzling. As described above, the literature on the conflict does not sufficiently address this empirical puzzle. Recognizing the fragility of my findings, as detailed in the following chapter, my research will make a contribution in this regard. 


\section{CHAPTER 3: METHODOLOGY}

\section{Introduction}

The conflict in Darfur has not only presented political, humanitarian and defence practitioners with many a puzzle, it has also confused researchers of conflict. Kuperman $(2005,2006,2008 \mathrm{a}, 2008 \mathrm{~b})$ has developed a theoretical framework that compellingly links moral hazard, created by both the broad norm of international humanitarian intervention and concrete, nearby cases of international intervention, to the occurrence of suicidal rebellions. The objective of this research is to test whether Kuperman's theory helps elucidate the empirical puzzle of the occurrence and timing of the rebellion in Darfur. George and Bennett (2005) thoroughly review and prescribe qualitative research methodologies in the social sciences; their work has guided my methodological choices. As I will detail below, I have chosen to conduct an in-depth single case study using process-tracing. I will briefly describe how I operationalized the research, as well as the means with which I gathered information to test the hypothesis. The challenging circumstances in which the evidence was collected underscore the fragility of my findings.

\section{Single case-study using process-tracing}

The objective of this research is to deductively test whether Kuperman's theory of moral hazard of international humanitarian intervention explains why the Sudan Liberation Army/Movement's leaders chose to instigate a rebellion against the government of Sudan in conditions in which genocidal retaliation against civilians appears to have been likely and rebel success unlikely; and why they did so in early 2003 . 
I am therefore seeking to improve the historical explanation of this conflict. In more abstract terms, the aim is to verify whether there is evidence that the causal mechanism identified by Kuperman describes why the SLA rebels behaved the way they did. Social scientists are increasingly choosing to analyze historical events and other phenomena via causal mechanisms (George and Bennett 2005, 135). This shift is rooted a recognition that events that shape history are complex and deserve detailed attention to the multiplicity of factors and causal mechanisms that shape them.

An in-depth case-study using process-tracing is best designed for this task. George and Bennett vigorously defend case-studies over other research methods, primarily quantitative research, for three reasons relevant to the objective of this research (2005, 19-22). First, case-studies have the potential to achieve high conceptual validity by allowing the researcher to capture the contextual factors and pursue a detailed understanding of the case. This enables them to identify and measure indicators that best represent the theoretical concepts that are being evaluated. Second, case-studies examine the causal mechanisms in individual cases in detail and are, therefore, a useful means of investigating the mechanisms hypothesized by a specific theory. Finally, case-studies serve an important heuristic function: they are likely to foster valid new hypotheses because they allow researchers to inductively observe unexpected factors by virtue of the thorough attention to each case.

Process-tracing is the natural ally of case-study research. It is a research method that aims to empirically identify and describe the intervening variables and causal processes (the causal chain and causal mechanisms) that are, or are believed to be, at play in the case. I am using a specific variety of process-tracing, the analytic explanation, which "converts a historical narrative into an analytical causal explanation couched in explicit 
theoretical forms" (George and Bennett 2005, 211). The researcher accomplishes this task by examining histories, archival documents and undertaking in-person interviews to assess whether the mechanisms and variables a theory hypothesizes are, in fact, evident (George and Bennett 2005, 6-7).

Single-case studies using process-tracing provide useful detailed analyses of historical events that are of interest to political scientists, historians and policy makers. This study seeks to contribute to the historical explanation of the onset of the conflict in Darfur and provide avenues for future research in these directions, as well as policy recommendations to practitioners in international and intrastate conflict.

\section{Operationalization of the research objective}

In order to test the applicability of Kuperman's theory to Darfur, I formulated a hypothesis that most accurately captures the central theses of the theory as they apply to the conflict. This led me to focus my analysis on one scenario hypothesized by Kuperman: whether the SLA's behaviour was fraudulent, or in other words, whether, as a result of the moral hazard of humanitarian intervention, the SLA leaders intentionally provoked a humanitarian catastrophe to advance their political objectives. Next, I generated assumptions and predictions that are implicit in the hypothesis. These encapsulate the intervening variables and steps that characterized the rebel leaders' decision-making process should the hypothesis compellingly describe the case. George and Bennett underline that when using process-tracing to test a theory, evidence must support each criterion generated from the hypothesis for the case-study to confirm the hypothesis, not a "statistically significant number of steps" (George and Bennett 2005, 207). If evidence does not support each of the criteria, then either the hypothesis does not 
compellingly explain the empirical puzzle, the theoretical framework/scope needs alteration, or the data is insufficient and/or erroneous. First, I will examine the evidence supporting the hypothesis, then the evidence undermining the hypothesis. I will subsequently assess both and draw limited conclusions as to the explanatory power of the hypothesis based on the evidence available to me.

\section{Sources of evidence}

To test Kuperman's hypothesis in the case of Darfur, I required detailed information on the timeline of the conflict, the intentions and actions of the rebel leadership, and the nature and evolution of the armed movements in Darfur, with a focus on the time-period between 2000 and 2003. I first drew evidence from the existing literature on the conflict, as detailed in Chapter 2. It is relevant to highlight that I undertook this research project in May 2007, before some of the most important work on the conflict had been published (specifically on the rebel movements: de Waal 2007; Tanner and Tubiana 2007). Incidentally, Kuperman (2008a, 2008b) had also not yet claimed that the crisis in Darfur exemplified his theoretical framework. Given that there was insufficient detailed information in the literature on these questions at that time and that archival and other documentation were not accessible to Canadian researchers, it was necessary to conduct in-depth interviews with individuals who were privy to and/or knowledgeable about the decision-making process of the SLA rebel leaders.

Tansey (2006) argues that in-person in-depth elite interviewing is the most effective and appropriate data-collection method for process-tracing. Open-ended, semi-structured conversations, as opposed to standardised questions, were best suited for the research 
question as they allowed flexibility to pursue issues I had not anticipated and tackle matters in depth and detail (Babbie and Benaquisto 2002, 344; Tansey 2006).

I used a combination of two non-probability sampling methods, snowball and purposive sampling (Babbie and Benaquisto 2002, 165-168). These best served the objectives of this study given the constraints of the terrain. Snowball sampling consists of locating a few key participants, and then asking them to locate other members of the target population. Snowball sampling is used in situations in which it is difficult to identify and locate appropriate participants. The selection of participants being "viral", it may result in a group of participants which represent only one "side" of the conflict as individuals tend to refer the researcher to other individuals with whom they share an understanding and/or interests (Biernacki and Waldorf 1981). However, the fluidity of power and shifting alliances in Khartoum, best described by de Waal $(2007,14)$, meant that this was not a significant problem for my sample. The second, purposive sampling, consists of selecting participants on the basis of the researcher's knowledge of the population and the purpose of the study. I, therefore, sought out individuals whom I suspected had information relevant to my research based on my literature review. ${ }^{25}$

\section{Field Work}

In total, I conducted 35 in-person interviews with the approval of the Ethics Review Board of Carleton University (see Annex 2). In July and August 2007, I traveled to Khartoum and London. My visa to Sudan was sponsored by Ahfad University for Women, Khartoum, where I worked as a volunteer on micro-credit programs for Darfuri women in the Dar-Es-Salaam IDP camp on the outskirts of the city. I interviewed 25

\footnotetext{
${ }^{25}$ Participants listed as "no contact", Annex 1.
} 
individuals in Khartoum between 11 July and 10 August, 2007. These included Hassan al-Turabi, one of the most powerful men in Sudan (bio detailed in Chapter 2); one Sudanese government official (a former Cabinet Minister in President Bashir's government); three parliamentarians (including the head of government delegation which negotiated with the SLA at the onset of the conflict); one journalist; one academic; nine members of civil society (including human rights lawyers, activists and development practitioners). I also spoke with one mid-level SLA leader and one SLA fighter; as well as two SPLA officials: Edward Leno, a senior SPLA officer and one junior SPLA political advisor. In addition, I interviewed one Sudanese United Nations personnel, two foreign United Nations personnel (including the Joint Deputy-Commander of UNMIS), one foreign NGO staff and one foreign contractor. The interviews ranged from thirty minutes to four hours. In addition, I interviewed two respondents twice and one respondent three times.

At the beginning of each interview, I reviewed verbally a letter of information and consent approved by the Carleton Ethics Review Board (see Annex 3). The participants then voiced any concerns or questions, to which I responded. Without exception, they agreed to proceed with the interview and consented to my using the information for this research paper. One individual requested their identity remain confidential; all others agreed to information being attributed to them. I did not ask the participants to sign the letter of consent because to do so would have put them at an unacceptable risk. The political regime in Sudan is oppressive in nature: the Sudanese security and intelligence services are ubiquitous in Khartoum and the government's grip on power is fluid. The government has voiced repeatedly its disdain for international interference in this conflict and there is a history of Sudanese rebel forces receiving material support from foreign 
governments. The ongoing conflict in Darfur was therefore a sensitive issue in Khartoum 2007. In addition, three respondents spoke of being arbitrarily arrested and imprisoned without charge, they suspected because of involvement in the conflict in Darfur and/or other political movements in Khartoum; one respondent spoke of being tortured in prison. For these reasons, I did not feel it was in the participant's best interest for me to keep paper proof that they had spoken to me. In addition, given the changing security situation in Sudan subsequent to the International Criminal Court arrest warrant being issued for President Bashir (4 March 2009) and the recent arrest and torture of Sudanese human rights activists in connection to these events, I have chosen to keep confidential the identities of individuals I interviewed in Sudan whom I believe may be vulnerable.

I conducted seven interviews in London, United Kingdom: one on 10 July 2007 and six between 12 August and 15 August, 2007. I interviewed one senior JEM leader; one Darfuri academic and Director at Justice Africa, an international NGO; one exiled Darfuri parliamentarian; the London-based SLA spokesman; one Darfuri activist associated with the SLA; and the British film-maker who captured the first video images of the conflict. I also conducted one interview with two British staff from Amnesty International. Before each interview, the participant reviewed and signed the approved letter of information and consent. Asking them to sign the letter did not present risks to their safety in London, but did create significant discomfort and puzzlement on the part of both Sudanese and British respondents. The interviews lasted between one and two hours.

I conducted one interview in Ottawa on 11 April 2008 and two interviews in New York City in August 2008 (one of which was conducted over the phone), all three of which were with Western individuals who were current or formerly affiliated with the UN in Sudan. Before each interview, I verbally reviewed with them the letter of information 
and consent, but did not request their signature given the discomfort doing so had created with the British and Sudanese participants in London. Two of the participants requested their identity remain confidential.

For the purposes of this research, the target population was individuals with insight into the decision-making process that led the Darfuri rebel leaders to launch the rebellion when they did in sub-optimal conditions. I was fortunate to locate two key respondents who put me in contact with a variety of individuals who had first hand experience with the rebel leaders. Tag el-Khazin, a Sudanese-born Canadian whom I met in Ottawa, had worked on conflict related issues in Sudan for over ten years. Given the policy relevance of my research topic, he agreed to put me in touch with, in his words, "all sides of the conflict". Through him I met with members of both Darfuri rebel groups (the SLA and JEM), Arab, Zaghawa and Fur Darfuri elites (including parliamentarians, former cabinet ministers and journalists), and SPLA officers.

My second key contact was Samia Ahmed, then a Consular/Human Security Officer at the Canadian Consulate in Khartoum. A Sudanese woman from a prominent Riverine tribe, she was also convinced of the importance of my research topic and agreed to put me in touch with her contacts. These included, among others, Hassan al-Turabi; Edward Leno, a senior SPLM leader; Ablagasim Seif Eldeen, a Darfuri parliamentarian, chief negotiator for the government at the onset of the conflict and father-in-law of Abdelwahid Mohammed al-Nur (leader of the SLA); human rights lawyers and Fur, Zaghawa and Arab activists. In addition, I asked each participant I interviewed to recommend other respondents, which many did. 


\section{Evidentiary value of the data collected through interviews}

As I will detail below, there are difficulties surrounding the validity of the data collected through in-person interviews. Added to these was the challenging and, at times, compromising context in which I collected the qualitative data. The inferences drawn in this research are, therefore, fragile and preliminary. Nevertheless, this research tentatively improves the historical explanation of the conflict.

Assessing the reliability of the data collected through personal recollections of complex historical events is challenging. Davies (2001) and George and Bennett (2005, 99-101) provide a framework for assessing whether the primary sources are representative, reliable and truthful. They encourage researchers to take into account four questions which amount to: who the participant is, how the researcher is perceived, why the participant has agreed to be interviewed and under what circumstances they are doing so. The information obtained should be from a first-hand witness (not based on hearsay); the level of access of the interviewee to the events in question should be known, with senior level elites to be viewed as more reliable; and, if possible, the interviewee's track record of reliability should be established, with a proven record ideally established before recollections are taken at face value.

The participants I interviewed represented all major groups that influenced and/or witnessed the decision-making process that led the SLA to choose when and how they rebelled. Many provided relatively detailed accounts of the timeline of the conflict, often relating back to the mid-1990s. I spent considerable time assessing their level of access to the SLA decision-making process and their reliability as witnesses. I am confident the respondents provided, for the most part, reliable information. Unfortunately, I was unable to interview top SLA leaders - individuals who made the decisions I am analyzing - 
primarily because they are either dead, in exile or not giving interviews. I did interview one JEM rebel leader, one mid-level SLA leader and one SLA fighter. Nevertheless, the vast majority of the participants had personal relations with the SLA leaders and most had spent time in Darfur in the company of these individuals in the lead up to and/or since the onset of the conflict. They were therefore able to provide reliable and insightful information on the timeline of the conflict and the leaders' intentions at its onset.

Perceptions of me likely influenced why the participants chose to speak with me, and while it may have dictated how much information they shared with me, it is unlikely that it significantly influenced the truthfulness of the their testimonies. I was a twenty-six year-old Canadian white woman conducting interviews on a politically sensitive subject matter in Khartoum. Unlike all other foreigners in Khartoum whom I met, I was not affiliated with a government, non-governmental organization or international institution. The Norman Paterson School of International Affairs and Carleton University are unknown in the city. This lack of affiliation was suspicious to at least one participant, who momentarily detained me because he believed I was a spy. It is reasonable to assume that this was a concern to other participants.

Despite these factors, 21 Sudanese individuals from diverse groups and of differing political and social standings agreed to speak with me in Khartoum, three of them on several occasions. It is reasonable to assume that they chose to do so for several reasons. First, many felt that my line of inquiry was an important one that had been, until then, ignored by Western academics. Second, Sudanese culture is one of great generosity and politeness; their regard for the individual recommending me would have created a social obligation to speak with me. Finally, some of those interviewed, especially those affiliated with the rebel movements or subjugated groups, may have believed speaking 
with me to be a means of communicating their message to the international community and/or securing international funds for their cause.

Language was not a significant obstacle in the collection of data. All interviews were held in English with the exception of four. One took place in French, which I speak fluently, at the request of the participant, and three were in Arabic with a translator provided by the participants. The translators were present when I reviewed the letter of information and consent and agreed to my using the information for this research. All of the non-Sudanese participants spoke English fluently as it was either their mother tongue or they worked in English on a daily basis for an international organization.

The most important factor that shaped the data I was able to collect was the nature of the regime in Sudan, coupled with the fact that the conflict was ongoing at the time of the interviews. These combined to make the conflict in Darfur a politically sensitive issue in Khartoum; speaking about the conflict was thus a risky exercise. As a general rule, the ten interviews I conducted in London, Ottawa and New York City were more fruitful in terms of detailed information on the actions and intentions of the SLA leaders in the lead up to the conflict, as compared to those in Khartoum. A second general observation is that the quality of information I was able to collect improved with the number of interviews I conducted. My understanding of the conflict and its key actors, the power dynamics within Sudan, and the security situation in Khartoum increased. This meant that I was able to better assess who likely had what information, and the propriety of me pursuing certain questions on such a politically sensitive question. In addition, unexpected variables and causal mechanisms came to light with time and I was able to cross-check these with other respondents. Each interview improved my grasp of the complexity of the Sudanese polity and why and how the conflict in Darfur started. My analysis is embedded 
in this understanding, yet I draw most of the evidence supporting this research from ten key-informant interviews.

Research on decision-making in the most benign circumstances is challenging; doing so on elite decision-making in conflict is especially difficult. Conflicts are fraught with ambiguous, incomplete and contradictory information; actors who hide their understanding of the conflict situation in the lead up to and during conflict, and distort it in the aftermath; and ill-structured problems to which there are multiple rational solutions (Mintz 1997, 1-7). It is important to note that all of the research on this conflict specifically, and most of what has been published on Darfur in general, has been undertaken while the conflict was ongoing. Therefore, many of the challenges I faced in collecting reliable data were also faced by scholars who came before and after me.

An example that illustrates the challenge of obtaining reliable information is the conflicting accounts of when the SLA published its political manifesto. Several participants I interviewed contradicted each other; most of the English language scholars also contradict each other. Flint claims it was made public on 16 March 2003 in both her article in War in Darfur $(2007,160)$ and in $A$ short history of a long war co-authored with de Waal $(2005,82)$. Yet the chronologies at the beginning/ending of both of these books claim it was published in February 2003. Burr and Collins report it was published on, approximately, 9 March 2003 (2007, 155). The "www.sudan.net" website, a Sudanese English language website about Sudan, posts a press release entitled "The Sudan Liberation Movement and Sudan Liberation Army: Political Declaration", and indicates having received the press release on March 14, 2003 at 13:42:53 Eastern Standard Time. This document is referred to throughout this paper as the "SLA/M's Political Declaration". I have therefore chosen 14 March as the release date, acknowledging that 
this is not a firm assumption.

\section{Conclusion}

This research seeks to help explain the empirical puzzle of the onset of the conflict in Darfur by testing the applicability the theoretical framework of the moral hazard of humanitarian intervention. The objective is to improve the historical explanation of the conflict and provide useful insights to international policy makers struggling with this and future situations. Using process-tracing, I conducted an in-depth analysis of the decisionmaking process that led the SLA leaders to instigate a rebellion against the government of Sudan in early 2003. I obtained detailed information on the conflict from Englishlanguage literature, news media and 35 in-person interviews. I then formulated a hypothesis that best captures the central components of Kuperman's theory as they apply to Darfur and tested it with the information I collected. While the details are difficult to nail down, collating the data and triangulating it with existing literature on the conflict in Darfur exposes new, coherent and consistent patterns that shed much needed light on the beginning of this devastating conflict. Next, I will explore the causal factors and mechanisms implicit in Kuperman's theory of the moral hazard of humanitarian intervention. 


\section{CHAPTER 4: KUPERMAN'S THEORETICAL FRAMEWORK}

\section{Introduction}

Building on the work of Rowlands and Carment (1998), Kuperman (2005, 2006, 2008a, 2008b) developed a theoretical framework that claims to explain why some subjugated groups instigate rebellions against militarily superior states when disproportionate retaliation is likely and success unlikely. Kuperman argues that the emerging norm of international humanitarian intervention can create a moral hazard which entices subjugated rebel groups to initiate suicidal rebellions. The norm would do so by creating the expectation that, should disproportionate state retaliation occur, the international community will intervene to protect civilians from genocidal violence and advance the subjugated group's political objectives. While Kuperman's analysis attributes moral hazard to the broad norm of humanitarian intervention, Crawford (2005) argues that specific actions by identifiable international actors have greater impact on the incentives of nearby subjugated groups and are, therefore, more likely to trigger suicidal rebellions.

Kuperman inductively developed the framework based on qualitative evidence from the 1992 Bosnian Muslim rebellion and the 1999 Kosovar Albanian rebellion. He has published three articles, one of which in International Studies Quarterly (2008a), and coedited one book in which he elaborates and refines the theory. In this chapter I will review Kuperman's theoretical framework, examine his case studies (Bosnia and Kosovo) and explore criticisms of the theory. 


\section{Theoretical framework: The moral hazard of humanitarian intervention}

\subsection{Dependent variable: suicidal rebellions}

Evidence suggests some subjugated rebel groups intentionally launch rebellions against a state without the military means of achieving their political objectives and at the risk of genocidal retaliation, even after the state threatens them with such retaliation. Kuperman seeks to explain this empirical puzzle, which he dubs "suicidal rebellions" (dependent variable). As I will detail below, by applying rational deterrence theory to intra-state actors, he hypothesises five possible reasons why "deterrence would fail": why a subjugated rebel movement would choose such a risky option.

In his 2005 article in Ethnopolitics, Kuperman refers to the research of Fein (1990), Harff and Gurr (1988), and Valentino, Huth, and Balch-Lindsay (2004) who demonstrate a little known and surprising fact: unlike the Holocaust, most genocidal violence occurs when members of a subjugated group challenge a state with violence, prompting the state to retaliate disproportionately to the threat with genocidal violence. In other words, while high levels of structural violence against the subjugated group are likely to have existed before the shooting wars began, empirical evidence shows that victims of genocide are often responsible for initially militarizing the conflict.

Kuperman defines genocidal violence as: "genocide and ethnic cleansing (forced migration)" (2005, 149). The UN Convention on the Prevention and Punishment of the Crime of Genocide defines genocide as: "acts committed with intent to destroy, in whole or in part, a national, ethnic, racial or religious group" (UN General Assembly 1948). Ethnic cleansing is the forced migration of a particular identity group from a territory (Kuperman 2008b, 220; Prunier 2005, 157). There is broad international agreement that 
genocidal violence encompasses genocide, war crimes ${ }^{26}$, ethnic cleansing and crimes against humanity ${ }^{27}$, as referred to in the Rome Statute of the International Criminal Court, ratified by 108 states (UN Rome Statute 2002) and in the outcome document of the 2005 World Summit, endorsed by 191 states (UN General Assembly 2005). Genocidal retaliation is such violence employed by a state in response to an armed challenge to its authority (Kuperman 2008b, 220).

Not only are most conflicts involving genocidal violence initiated by the eventual victims of the violence, they are suicidal insofar as these groups challenge the authority of the states without the means (military, political, financial and/or other) of achieving their political objectives. Furthermore, the state often threatens genocidal retaliation (Kuperman 2005, 156). The natural question is: why would a group intentionally instigate violence against the state if it is unlikely to succeed and likely to be subjected to genocidal violence?

The question is of particular interest because, not only are these rebellions counterintuitive and surprisingly prevalent, the literature on conflict does not compellingly explain them (Kuperman 2005, 2008a). Indeed, Kuperman argues that while the literature aims to provide insight into why, how and when rebellions occur, with attention to the behavior of rebel leaders and mass mobilization, it does not provide a rational explanation as to why a group would launch a suicidal rebellion. Kuperman focuses on three predominant theories of rebellion which respectively identify greed, grievance, and the security dilemma as the determinants of rebellion. The greed

\footnotetext{
${ }^{26}$ Violations of the laws of customs of war; devastation not justified by military necessity. See Article 8 of the Rome Statute and Article 6 (b) of the Constitution of the International Military Tribunal (Nuremburg Trial Proceedings).

${ }^{27}$ Inhumane acts committed against any civilian population, notably murder, extermination, enslavement, deportation; or persecutions on political, racial or religious grounds. See Article 7 of the Rome Statute Article 6 (c) of the Constitution of the International Military Tribunal (Nuremburg Trial Proceedings)
} 
hypothesis posits that groups are more likely to rebel when they believe they are able to gain power, regardless of whether they feel any grievance or threat (Collier and Hoeffler 2004). The grievance hypothesis posits that groups rebel to redress perceived deprivation, when political opportunity structures open the possibility of success (Davies 1971). The security dilemma hypothesis posits that groups rebel because they feel threatened, in particular when the central authority provides inadequate protection from the threat of violence by other groups (Posen 1993). All three theories assume rebel groups will only rebel when chances of success are reasonable.

"But none of these theories," argues Kuperman, "provides a satisfactory account of why a group vulnerable to genocidal retaliation would risk provoking that outcome by launching a rebellion. Suicide does not satisfy greed, rectify grievance, or mitigate insecurity" (2008a, 53). While Kuperman concedes that modeling the behavior as irrational may explain some suicidal rebellions, he hypothesizes that others can be rationalized. He bases this hypothesis in rational deterrence theory, which claims that states considering the use of military force against another compare the expected gains/losses from using force with that of refraining from a military challenge (status quo), and chooses the option with the greatest expected utility (Huth 1999, 28-29). Deterrence "works" when both parties expect to gain more from the status quo (no conflict) than from conflict. Translated to the domestic realm, the state can be viewed as attempting to deter rebellion by threatening massive retaliation (Kuperman 2008a, 55). The status quo (no rebellion) is, therefore, mutually beneficial: the rebels are not subjected to genocidal retaliation and the state's authority is not challenged. It follows that something must change in this context to make deterrence fail, enticing the 
subordinate group to launch a rebellion. Kuperman's objective is to identify the causal factor(s) (the independent variable(s)) in this decision.

Kuperman makes the case that there are five possible reasons consistent with rational deterrence theory why a militarily inferior group would launch a suicidal rebellion (Table 1). First, the rebels do not perceive as credible the threat by the state to retaliate. Second, they expect state victimization regardless of their actions, so believe they have nothing to lose by instigating rebellion. Third, the rebels believe they have, or have the ability to build, the forces necessary to achieve their political objectives on their own at, what they perceive, tolerable cost. $^{28}$ Fourth, the subjugated group believes the international community will intervene to enable it to achieve its political objectives at tolerable cost. Fifth, the rebel movement does not behave as a unitary rational actor and, therefore, other factors explain its decision to launch a suicidal rebellion. ${ }^{29}$

Kuperman is interested in the fourth option. He hypothesizes that when the four other options do not describe the rebel groups' perceptions at the time of decision, then the rebel leaders are likely to have rebelled in sub-optimal conditions because they expected the international community to compensate for their lack of military capabilities and enable them to achieve their political objectives at tolerable cost, despite the sub-optimal conditions. This expectation is best described by the concept of moral hazard.

\footnotetext{
28 "Tolerable cost" refers to the number of civilian and military casualties the rebel group is willing to accept to achieve their political objectives.

${ }^{29}$ Rational deterrence theory rests on the rational actor assumption, which posits that it is useful to assume that decision-makers act as if they are unitary and rational. Rational actors do what they believe to be in their best interest at the time of the decision; unitary actors are governed by a single decision-maker (Morrow 1997). Kuperman includes the "unitary" assumption in his model in order to preclude non-unitary decision-making theories (such as bureaucratic decision-making), which would make the theory less sparse. Social scientists primarily draw on organizational theory and cognitive psychology to question the capacity of individual decision makers and military organizations to act rationally (Huth 1999). For a good comparative discussion of the usefulness of rational choice, organizational and cognitive theories as applied to international relations see Geva and Mintz (1997).
} 


\subsection{Independent-variable: Moral hazard}

Moral hazard is a perverse effect of insurance: it is the presence of incentives to take risk or act fraudulently where there is protection (or the expectation of protection) against its consequences (Crawford 2005, 178). People with insurance therefore tend to behave in a way that increases claims against the insurance company (Rauchhaus 2005, 217). Two ideas are central to this concept. First, as Crawford (2005) underlines, the concept denotes a relationship of influence exercised by those who create incentives over the behaviour of those who respond to them: actor A (insurer) incites actor B to do things they believe to be in their interest and that they would not otherwise do. Second, these incentives are perverse: they stimulate undesirable behaviour by promising to reward it. Therefore, actor B's actions are harmful to the interests of actor A. Both criteria must be present for moral hazard to exist. In this context, the international community is perceived as an insurance company (actor A) by subjugated rebel forces (actor B).

Kuperman provides two often quoted examples of moral hazard in the economic realm. Insuring vehicles against theft may lead owners to irresponsibly park in cheaper but less secure spaces, or even to fraudulently arrange for their car to be stolen (if it is insured for more than the resale value), thereby increasing car theft and claims against insurance companies $(2008 \mathrm{a}, 50)$. This problem also occurs even when the protection is not guaranteed but merely probable. For example, Kuperman states that financiers are more likely to make irresponsible loans to risky countries because they know the International Monetary Fund often protects these countries from default by infusing capital, even though such bailout is not guaranteed (2008a, 50).

The concept of moral hazard was first used in the nineteenth-century fire insurance trade and represented an "unwholesome mix of bad character and temptation which the 
insurance companies had a responsibility to ferret out of the insurance enterprise" (Baker 1996, 240). In the late 1960s, Pauly (1968) and Nobel Prize winning economist Kenneth Arrow (1970) imported the insurance concept of moral hazard into economics, where it flourished. Yet, "moral hazard is not simply something provided by 'insurance companies'. It is provided any time that one party's actions have consequences for the risk of loss borne by another" (Baker 1996, 272). Thus, in recent years, political scientists have borrowed the concept to understand the impact of third party intervention on the instigation and intensity of conflict (Rowlands and Carment 1998; Rauchhaus 2005).

\subsubsection{A relationship of influence}

For moral hazard to exist, actor A (insurer) must behave in a way that incites actor B to make choices they believe to be in their interest and would not make otherwise. Kuperman hypothesizes that the international community creates the expectation that severe abuse of human rights will trigger international intervention to stop the violence, protect civilian life and alleviate suffering. Both the norm of international humanitarian intervention and specific interventions which operationalize the norm can create this expectation. Because some subjugated rebel groups expect to benefit from, or at least be protected by such intervention, they choose to rebel in dangerous conditions in which they would not otherwise.

\subsubsection{The norm of international humanitarian intervention}

In the early 1990s, the world witnessed several major humanitarian catastrophes, notably in the former Yugoslavia, Somalia, Liberia and Rwanda. In response to these "conscience-shocking situations crying out for action" (ICISS 2001, 62) hitting television 
screens the world over, international non-governmental organizations (NGOs), Western media outlets, international organizations and Western governments began advocating a new justification for diplomatic, economic and/or militarily intervention in sovereign states: the protection of civilians (Ayoob 2002; Gilboa 2005). The impetus to protect civilians (non-combatants) stems from the humanitarian imperative founded on the common dignity of humankind, regardless of differences in race, gender, religion, national belonging, political creed, or any other accident of birth or contextual circumstance (ICRC 1999; Belloni 2005, 1). The most flagrant and urgent abuse of human rights from which civilians need protection is genocidal violence.

Kuperman $(2008 \mathrm{a}, 2008 \mathrm{~b})$ defines humanitarian intervention based on the definition put forward in the Responsibility to Protect report (ICISS 2001, 8). It is intervention in the affairs of a state that is motivated by the desire to protect civilian targets of state violence. Actions which have the same impact but are motivated by other factors, notably national interest, do not qualify as humanitarian. In concrete terms, humanitarian intervention includes: rhetorical condemnation, threats or imposition of economic sanctions, recognizing the independence of secessionist entities, air strikes on military or economic assets, military assistance to or coordination with rebels perceived as defending at-risk civilians, consensual deployment of peacekeepers, and nonconsensual deployment of troops for peace enforcement. The international community also habitually provides a framework for power and wealth sharing negotiations for the parties to the conflict in order to create conditions for sustainable peace (Johnston 2007; Kriesberg 2007). While some scholars and humanitarian practitioners take issue with actions of military and political nature being labeled "humanitarian" (ICISS 2001, 9; Orbinski 2008), for the 
purposes of this research I will assume that all international action undertaken to protect civilians from egregious violence is "humanitarian".

The post-Cold War transformation which allowed for humanitarian intervention was the shift toward a uni-polar world: the United States emerged as the sole superpower (Freedman 2007, 246-248). Free to set the international security agenda, Western governments successfully argued that intra-state conflict and the resulting humanitarian crises were threats to "international peace and security", which led the UN Security Council to mandate intervention in Somalia, Liberia, Rwanda, Haiti, Sierra Leone, and Kosovo $^{30}$ (Hamilton 2006). October 1999 was the first time the Security Council formally extended its powers under Chapter VII of the UN Charter to civilian protection (in the mandate of UN Mission in Sierra Leone) (UNSC 1999).

World leaders such as Kofi Annan ${ }^{31}$ used their pulpits to publicly urge states to embrace the new international doctrine to halt atrocities (Power 2008, 240). The redefinition of state sovereignty as responsibility ${ }^{32}$ (Deng et al. 1996; Ayoob 2002) crystallized with the publication of the Responsibility to Protect report by the International Commission on Intervention and State Sovereignty (ICISS) in December 2001. The report provides a legal foundation and guidelines to:

Where a population is suffering serious harm, as a result of internal war, insurgency, repression or state failure, and the state in question is unwilling or unable to halt or avert it, the principle of non-intervention yields to the international responsibility to protect" (ICISS $2001, \mathrm{XI})$.

\footnotetext{
${ }^{30}$ International intervention in Kosovo was initially undertaken by the North Atlantic Treaty Organization (NATO), but was later mandated by the UN Security Council Resolution 1244 on 10 June 1999.

${ }^{31}$ Secretary General of the United Nations from 1997 to 2007.

${ }^{32}$ Responsibility toward the state's citizens, as opposed to sovereignty being a state's right protecting it from interference/intervention from other states.
} 
In September 2005, 191 states endorsed the World Summit Outcome document which officially sanctioned the principles of the "Responsibility to Protect" doctrine (UN General Assembly 2005).

While intervention in the internal affairs of states was not new, the rhetoric and momentum around intervention to protect civilians was. International action intended to protect civilians from egregious abuse, coupled with strong rhetorical commitments by the UN, Western governments, the media and NGOs, set precedents (Wheeler 2004; Crawford 2005; Hamilton 2006). They shaped a norm and, thus, created the expectation among international actors that the international community would intervene to stop genocidal violence.

\subsubsection{Responding to the incentive}

Insurgent leaders have reason to believe that such intervention would artificially inflate the strength of their group vis-à-vis the state. Practically speaking, they may expect the international community to protect civilians, allowing them to devote military resources elsewhere. They may also assume the international community would deter the state from using disproportionate violence against civilians and, perhaps, rebel fighters. In addition, they may expect the international community to entice the government to negotiate a political settlement.

Kuperman spells out two ways the rebels could strategically respond to the incentive created by the international community. The rebel leaders could act "irresponsibly": rebel in conditions in which they fear genocidal retaliation and have little chance of success on their own because they believe the international community will act as a safety-net should catastrophe occur. Or, they could engage in "fraudulent behavior" by initiating violence 
against the state with the intention of provoking retaliation against civilians in order to deliberately create a humanitarian catastrophe. Rebels would engage in such Machiavellian behaviour as international attention and intervention, which they deem necessary to success, is difficult to garner. Keck and Sikkink suggest that because international support forms more easily around issues involving a threat to physical integrity, rebel leaders can be tempted to initiate violence against their oppressors to attract international sympathy $(1998,27)$. While fraudulent behavior is of greater consequence for the moral character of the rebel leaders, both risky and fraudulent behaviour imply the rebels chose to instigate violence against the state as a result of a precedent set by the international community.

It is important to acknowledge that the international community's track record of intervention is poor. Interventions intended to protect civilians have been inefficient, ineffective and half-hearted; the distance between rhetoric and action has led many scholars and practitioners to question the feasibility and integrity of these objectives; and principled opposition within certain states, in particular the Non-Aligned Movement (i.e. the likely recipients of such intervention) remains strong (Jentleson 2007; Weil 2008). Yet Kuperman emphasizes that the hypothesis does not presuppose that rebel leaders correctly assess the prospect of humanitarian intervention (2008a, 54). The instigating factor is rebel expectation of intervention (moral hazard), not the actual prospects of it happening, or happening effectively. As he points out, "in practice, intervention does sometimes help rebels attain their goals, but usually it is too late or inadequate to avert retaliation against civilians. Thus, the emerging norm causes some genocidal violence that otherwise would not occur" (Kuperman 2008a, 51). 


\subsubsection{Proximate international intervention}

As detailed above, Kuperman argues that the norm of humanitarian intervention creates moral hazard for some rebel groups. Yet Crawford provides evidence that moral hazard of humanitarian intervention is greatest and its impact on rebel decision-making more easily measured when identifiable international actors intervene in a specific conflict/situation near the rebel group in question $(2005,181-8)$. The intervention has a direct impact on the strategic context in which adjacent rebel groups operate, and renders it more likely to trigger suicidal rebellions than the diffuse norm. Although not necessarily, such interventions are often couched in the norm and its discourse, which they both exemplify and reinforce. ${ }^{33}$ Moral hazard can therefore be created by the norm of international humanitarian intervention, by specific nearby interventions or by a combination of both. I will provide a more detailed analysis of this later in the chapter.

\subsubsection{Perverse and unintended outcomes}

The second characteristic of moral hazard is the existence of incentives that are perverse for the party creating them: actor $\mathrm{B}$ must behave in a way that is contrary to the interests of actor A. Within the confines of rational choice theory, a perverse outcome is necessarily unintended. Therefore, the direct and/or indirect outcomes must be both perverse for and unintended by the international actors that created the moral hazard. While Kuperman does not explicitly consider this second criterion in his analysis, it is relevant to this case study. It goes without saying that rebellion (direct outcome) and genocidal retaliation (indirect outcome) are harmful to the interests of the international

\footnotetext{
${ }^{33}$ International intervention motivated by non-humanitarian reasons could have the same impact, although it would be less likely to lead proximate rebel groups to believe the international community would intervene should genocidal violence occur.
} 
community for both normative (UN General Assembly 2005, para. 138) and practical reasons (geopolitical stability, trade, diplomatic and financial resources). Furthermore, the shock value of this argument stems from the fact that the norm of humanitarian intervention appears to provoke the very abuse it aims to prevent. However, if moral hazard is attributed to the actions of specific international actors, then it is necessary to investigate this criterion in detail.

\section{Kuperman's case-studies: Bosnia and Kosovo}

Kuperman was alerted to the puzzle of suicidal rebellion while researching the conflicts in Bosnia (1992) and Kosovo (1999-2000), two former Yugoslav republics. He inductively developed a theoretical framework which explains the puzzle based on data collected for his 2002 doctoral dissertation entitled "The Moral Hazard of Humanitarian Intervention".

Kuperman tested the hypotheses of rational deterrence theory ${ }^{34}$ by process-tracing the actions of the Bosnian Muslim and Kosovo Albanian groups. He relied on interviews with at least a dozen leaders of each, including the eventual presidents of Bosnia and Kosovo, leaders of political parties, senior rebel officers, clandestine weapons procurers, and diplomats in charge of external relations. To mitigate the risk that officials misrepresented history in their own interests, Kuperman cross-checked the testimonies against journalistic accounts of the time and interviews with political opponents. In each case, he argues that a coherent and consistent account emerged supporting the hypothesis that rebel forces instigated conflict because they expected international intervention to enable victory at tolerable cost.

\footnotetext{
${ }^{34}$ As discussed above, and in Chapter 1 (Table 1).
} 


\subsection{Conflict in Bosnia (1992)}

On 25 June 1991, the republics of Slovenia and Croatia declared independence from the socialist federation of Yugoslavia, which had held together since 1948 despite deepseated animosities from centuries past among the different ethnic, cultural and religious groups (Murphy 1996, 198). This declaration of independence triggered events that would unravel the federation. It provoked the Serb-dominated federal Yugoslav People's Army (JNA) to attack Slovenia and Croatia. Within weeks, European diplomatic intervention succeeded in convincing the JNA forces to withdraw from Slovenia, but not from Croatia. The JNA, with the help of Croatia-based Serb militias, reclaimed most of the Serbinhabited territory. The campaign was brutal: by autumn 1991, it had killed many and created thousands of displaced (Cohen 1993, 225-6); ${ }^{35} \mathrm{UN}$ agencies intervened to quell the humanitarian crisis. In early 1992, the UN Security Council established a Chapter VIII UN Protection Force (UNPROFOR), headquartered in Sarajevo (the capital of Bosnia), with a mandate to ensure the demilitarization of designated areas in Croatia in view of creating "the conditions of peace and security required for the negotiation of an overall settlement of the Yugoslav crisis" (DPKO 1996).

It is at this moment that the conflict shifted to Bosnia-Herzegovina, which contained a majority Muslim population, with significant Serb (30 percent) and Croat minorities. Serbia and Croatia began arming these minorities against the Bosnian Muslims. The former were well equipped whereas the latter were unable to obtain adequate arms to defend themselves due to a Security Council arms embargo. In April 1992, the United

\footnotetext{
${ }^{35}$ Firm numbers on mortality resulting from the conflict are unavailable. Serbian leader Slobodan Milosevic was charged by the International Criminal Tribunal for the Former Yugoslavia with multiple counts of murder, torture, detention, deportation and other atrocities allegedly committed during the attempted ethnic cleansing of Croatia from 1991 to 1992 (ICTY 2001).
} 
States and other North Atlantic Treaty Organization (NATO) countries agreed to recognize Bosnia's independence. Bosnian Muslim leaders had rejected negotiated alternatives to remain in Yugoslavia or to divide Bosnia-Herzegovina into ethnic cantons; instead, they initiated armed secession. Days before international recognition of an independent, unitary Bosnia-Herzegovina, the republic's Serbs, supported by Belgrade, launched a brutal military campaign to capture most of Bosnia's territory and purge it of non-Serbs (Kuperman 2008a, 57). The violence that ensued was characterized by most international observers as ethnic cleansing perpetrated by Serb forces against Bosnian Muslims (Murphy 1996, 202). During an eventual 3.5 years of war, an estimated 103,000 Bosnians were killed, mostly Muslims (Tabeau and Bijak 2005) ${ }^{36}$ At the height of the conflict in Bosnia, there were around 1.2 million internally displaced persons (IDPs) and 1.4 million "war-affected" 37 (UNHCR/WFP 1998, 3).

Kuperman provides evidence that suggests the Bosnian Muslims did perceive as credible Serb threats that an armed secession would be met with genocidal retaliation. Given that the population of Bosnia-Herzegovna was over 30 percent Serb, the Bosnian Muslims would have had reason to believe the Serb-dominated JNA would react to a Bosnian declaration of independence as they had to a Croatian declaration (where only 13 percent of the population was Serb). In addition, the Serbs repeatedly threatened massive retaliation should Bosnian Muslims declare independence: Kuperman quotes several

\footnotetext{
${ }^{36}$ Tabeau and Bijak (2005) estimated 54 percent of those killed were civilian. They calculated conflict related mortality by verifying the identity of the individuals reported in all mortality sources, by comparing these records with those from the 1991 population census for Bosnia and the vote registers from 1997 and 1998. Death records linked with records of survivors (the 1997-98 voters) were excluded. This provided minimum number of confirmed deaths that occurred in Bosnia in 1992-1995. The records of fallen soldiers made it possible to distinguish between civilians and soldiers. They corrected the minimum numbers for the incomplete matching rate (approximately 20 percent information loss).

37 "War affected" refers to people who had no means of supporting themselves, but were not displaced (UNHCR/WFP 1998).
} 
threatening public statements made by Bosnian Serb leader Radovan Karadzic before the Bosnian Muslim secession (2008a, 58). Kuperman also interviewed Muslim leaders who confirmed they were aware of the Serb military build-up ahead of the declaration of independence and perceived the threats of retaliation as credible $(2008 \mathrm{a}, 58)$.

In addition, the Bosnian Muslims did not believe genocidal retaliation was inevitable; they therefore did believe they had something to lose by unilaterally declaring independence. Kuperman states that of those he interviewed, "most conceded that they did not fear genocidal violence-or even political disenfranchisement as had befallen Kosovo's largely Muslim, ethnic Albanians-so long as Bosnia stayed part of Yugoslavia" $(2008 \mathrm{a}, 59)$. Although the Muslim leaders were not of a single mind on the issue, they also recognized they could have avoided war by accepting the cantonization of Bosnia. The most influential decision-makers rejected the latter because they believed a unitary Bosnia could be achieved at the cost of war, which they preferred to peacefully accepting a Muslim “mini-state”.

In addition, the Bosnian Muslims did not believe they alone (or with the support of the Croats) could achieve military victory over the Serb forces. Kuperman quotes two key-respondents: Hasan Cengic, who was responsible for clandestine arms procurement, stated in 2000 that "we knew we were very, very, very weak and not capable of defending ourselves... We were already 100-percent occupied" (2008a, 60). Sefer Halilovic, head of the Muslim militia at the time of secession, told Kuperman in 1999 that he "knew his rudimentary troops were woefully unprepared to defend against Serb forces" $(2008 \mathrm{a}, 60)$.

They did expect, however, the international community to launch a humanitarian intervention which would enable them to prevail over the Serb forces. The Bosnian Muslim officials interviewed by Kuperman were aware of the American government's 
decision to lead a UN Security Council mandated force to expel Iraqi forces from Kuwait in 1991 and the subsequent military intervention in Kurdish Iraq intended to protect civilians from atrocities perpetrated by Saddam Hussein's forces (2008a, 62). These officials, therefore, engaged in a campaign to gain international support before they instigated armed secession (Kuperman 2005, 158). Bosnia's eventual foreign minister, Haris Silajdzic, confirmed to Kuperman in a personal communication (1999): "my main priority in the whole strategy was to get Western governments and especially the United States to get involved, because [Serbs] had the whole Army" (Kuperman 2005, 158). In addition, Kuperman quotes Bosnia's vice-president at the time, Muhamed Cengic (2000): "especially after UNPROFOR deployed in Bosnia for the Croatian peacekeeping mission... we really believed [protection was assured]" (2008a, 62).

The evidence presented by Kuperman compellingly suggests that had it not been for the expectation of international intervention, the Muslims might not have seceded. "At the very least, without the moral hazard created by the prospect of intervention, the Muslims would have militarily prepared themselves better before declaring independence, and thereby mitigated the potential genocidal retaliation" (Kuperman 2005, 159).

\subsection{Conflict in Kosovo (1999)}

Six years later, conflict flared up in nearby Kosovo. Formerly an autonomous region in southern Serbia, Kosovo had a multi-ethnic population with approximately 90 percent ethnic Albanian, 5 percent Serb and 5 percent made up of other ethnic groups. Historically, the region enjoyed a high degree of autonomy within the former Yugoslavia. In 1989, Serbian leader Slobodan Milosevic altered the status of the region, removing its autonomy and bringing it under the direct control of Belgrade, the Serbian capital (ICTY 
1999). ${ }^{38}$ The move was strenuously opposed by Kosovo Albanians and led to "apartheidlike oppression" in the province (ICG 1998b, 4).

In early 1998, Albanian militants of the Kosovo Liberation Army (KLA) ${ }^{39}$ launched a full-scale rebellion with the objective of achieving independence for Kosovo (ICG 1998b, 4-5). The insurrection prompted Belgrade to retaliate with a restrained counter-insurgency that targeted the KLA rebels, but in the process killed several hundred civilians and created a sizable humanitarian catastrophe. By 1 September 1998, UNHCR reported 241,700 persons displaced as a result of the conflict (UNHCR 1998). Over the course of 1998 and early 1999, under the leadership of the United States, the North Atlantic Treaty Organization (NATO) threatened to intervene militarily. In February 1999, they explicitly warned of an air-strike campaign against Yugoslavia unless President Milosevic accepted a US-brokered peace agreement. Belgrade initially acquiesced, but when the KLA took advantage of this reprieve to make military advances, Belgrade ignored the international threat and responded by targeting Kosovo Albanian civilians. The destabilizing role of the conflict and the growing humanitarian crisis motivated NATO intervention on 24 March 1999 (NATO 1999). An 11 week multinational air-strike campaign against Serb forces ensued.

Spiegel and Salama (2000) published epidemiological research in The Lancet demonstrating that an estimated that 12,000 deaths could be attributed to war related

\footnotetext{
${ }^{38}$ The change also made mandatory the use of the Serbo-Croatian language in its government institutions, and removed Albanians from most government jobs; a new Serb police force also harassed Albanians in its search for alleged separatists (Kuperman 2008a, 65). As a means of non-violent resistance, a parallel Kosovar society emerged within the province, including political, education and health-care institutions that exist outside the framework of the Serbian state (ICG 1998a).

${ }^{39}$ The Albanian acronym is "UCK" (ICG 1998b, 1).
} 
trauma. $^{40}$ The United Nations High Commissioner for Refugees (UNHCR), which coordinated the international relief effort, reported that nearly 860,000 Kosovo Albanians fled or were expelled from the province by Serb forces (Barutciski et al. 2000, 5); this amounted to approximately one half of the Kosovo Albanian population.

The Kosovo Albanian leaders, both those in the Democratic League of Kosovo $(\mathrm{LDK})^{41}$ and the armed KLA, appear to have expected massive retaliation from Serb forces should they secede militarily. Rugova, the leader of the LDK, said that Belgrade officials warned him explicitly in late 1997 that any rebellion "meant war" and that they had developed "a scorched-earth plan that could be implemented in 24 hours to destroy Albanian villages" (Richburg 2002). In addition, Hashim Thaci, a founder of the KLA and head of its political directorate during the war, conceded: "we knew full well that any armed action we undertook would trigger a ruthless retaliation by Serbs against our people... We knew we were endangering civilian lives, too, a great number of lives" (Kuperman 2008a, 67).

Evidence also suggests the Kosovo Albanians did not believe genocidal retaliation was inevitable: referencing the work of Salla (1995), Kuperman notes that the Albanians' disciplined campaign of nonviolence during the 1990s had meant that there were few cases of violent confrontation.

\footnotetext{
${ }^{40}$ In September 1999, Spiegel and Salama conducted a two-stage cluster survey among the Kosovo Albanian population in Kosovo. They collected retrospective mortality data, including cause of death, for the period from February 1998 through June 1999. The survey included 1197 households comprising 8605 people. 67 out of the 105 deaths reported in the sample population were attributed to war-related trauma, which extrapolates to be 12,000 deaths if the same war-related mortality rate is applied to Kosovo's total population. The authors were unable to differentiate completely between civilian and military casualties (Spiegel and Salama 2000). Few deaths were attributed to the NATO bombing campaign.

${ }_{41}^{4}$ Led by Ibrahim Rugova, the party formed a "parallel government" and was at the helm of efforts to gain independence by pacific means during the 1990s.
} 
They also did not believe they had the military capabilities to defeat Serb forces at tolerable cost without intervention. Until 1997, Albanian militants possessed no more than a few hundred weapons throughout the entire province, claims Kuperman. In-person interviews conducted by Kuperman (2008a) revealed that this was not by choice or principal, but rather because the Kosovo Albanians were unable to procure weapons. At the time of the insurrection, the KLA benefited from the disintegration of the Albanian army in the spring of 1997, and the looting of its military depots (ICG 1998b, 3). ${ }^{42}$ Despite this wealth of small arms, the pro-Belgrade forces remained much stronger, amounting to 34,000 troops (Kuperman 2008a, 68). A top KLA commander, Emrush Xhemajli (2000), admitted: "we knew our attacks would not have any military value. Our goal was not to destroy the Serb military force" (Kuperman 2008a, 69).

In fact, their strategy appears to have been quite the contrary. The Kosovo Albanian leaders expected the international community to launch a humanitarian intervention which would enable them to prevail over the Serb forces, and intentionally provoked violence against civilians to achieve this aim. Xhemajli revealed that his attacks were intended to "make the enemy show its real face-become more vicious" (Kuperman 2008a, 69). The Kosovo Albanian leaders did so because they perceived as credible the Western threats against Belgrade. Kuperman reports that Ibrahim Berisha, one of the five co-founders of the Democratic League of Kosovo, stated:

We perceived the change in 1996-1997. The rhetoric of world leaders versus Milosevic changed after that. They threatened Milosevic not to use force or commit crimes. If it had been said by small powers, it wouldn't have meant anything, but it was said by America and world powers. Our men who were armed in those days understood that signal. (Kuperman 2008a, 69)

\footnotetext{
42 The International Crisis Group reports that: "this resulted in the disappearance of between 700,000 and 800,000 weapons, many of which found their way into Kosovo" (1998b, 3).
} 
Therefore, Kuperman provides evidence that explains the initial divergence in approach between Kosovo's Albanians and Bosnia's Muslims, as well as the evolution of the Albanians' strategy over time. He also accounts for why Kosovo's Albanians refrained from violence for nearly a decade even though they suffered significant oppression, whereas Bosnia's Muslims opted for armed secession while enjoying full rights. Finally, he offers a likely explanation of why the Albanians eventually resorted to rebellion despite Belgrade's overwhelming military superiority and history of genocidal retaliation (Kuperman 2008a, 67). Both rebellions appear likely to have been triggered by the moral hazard of humanitarian intervention.

\section{Critique of Kuperman's theoretical framework}

Kuperman's hypothesis of the moral hazard of humanitarian intervention has come under some criticism, of which Western (2005) provides the most compelling. As I will examine below, he argues that a closer examination of the framework's empirical record and concepts reveal flaws in Kuperman's criteria for defining "suicidal rebellions", as well as with the timeline of the emergence of the norm of international intervention. In addition, Western (2005) and other authors argue that Kuperman's variables are underspecified. While these criticisms are compelling and reveal room for improving Kuperman's theory, they do not undermine as such its logical mechanisms, nor do they bring into question the exercise of testing its applicability to the conflict in Darfur.

\subsection{Rebellions which are not suicidal?}

Western (2005) raises two empirical critiques of Kuperman's argument. First, for a rebellion to be suicidal, the victim group must intentionally choose a path that is harmful 
to itself. Western questions the empirical accuracy of Kuperman's initial puzzle - the claim that most victims of genocidal violence are responsible for initially militarizing conflict and provoking genocide. Western argues that under closer examination, the data Kuperman uses to substantiate his claim $^{43}$ does not necessarily demonstrate that a majority of genocidal violence was provoked by the victim group. If the violence was not initiated by the victim group, then the rebellions in question were not suicidal (Western $2005,227)$. Western applies the same critique to both of Kuperman's case studies. He argues that in both Bosnia and Kosovo, "a gradual escalations of political contestation, repression and opposition, and ultimately violence" characterizes the onset of the conflicts (Western 2005, 230). This undermines the argument that the rebellions were initiated (provoked) by the victim groups and, therefore, questions their suicidal nature. While this is a valid point, Kuperman demonstrates that both rebellions were intentionally launched by the respective rebel groups (the actions of their forces are likely to have been the consequence of the rebel decision-makers), were offensive in nature, and marked a clear break in the conflict dynamic. Therefore, while structural and low-level violence existed before both rebellions, this does not preclude the rebellions in Bosnia and Kosovo from being suicidal.

\subsection{No norm of international humanitarian intervention?}

Second, for the occurrence of a rebellion to be explained by the moral hazard of humanitarian intervention, the norm of humanitarian intervention must exist prior to/at the onset of the conflict. Drawing on the work of Kier and Mercer (1996), Western (2005) questions whether the norm of international intervention existed prior to the rebellion in

\footnotetext{
${ }^{43}$ Fein 1990; Harff and Gurr 1988; Valentino, Huth, and Balch-Lindsay 2004
} 
Bosnia, implying the rebellion cannot be attributed to it. A norm takes time to solidify: only after repeated precedents are set and there is a clear and shared sense of the conditions in which such action will take place does a norm emerge, argues Western (2005, 231-232). The Bosnian Muslims rebelled in March 1992, two and a half years after the fall of the Berlin Wall. At this time, humanitarian crises raged largely unabated by international action in Somalia and Iraq. Most scholars agree the norm of humanitarian intervention did not yet exist, nor did the international community (or specific international actors, notably the United States) signal that they would intervene in support of the Bosnian Muslims (Power 2008, 225-248). Murphy makes the point succinctly:

The conflict in Bosnia-Herzegovina exemplified how neither the international community nor states acting in their individual capacity perceived a legal or perhaps even moral obligation or duty to act in situations in which there are widespread and severe human rights atrocities, at least where there are broader security concerns at stake $(1996,216)$.

However, Kuperman's independent variable is moral hazard, or the expectation of international intervention; he presents compelling evidence that the Bosnian leaders believed intervention was likely and rebelled when they did as a consequence.

\subsection{The causal connection between norm and moral hazard}

Third, Western (2005) and Crawford (2005) make a broader critique of the theoretical framework. They contend that Kuperman's focus on the causal relationship between the norm of international intervention and moral hazard is overstated. Neither believes, however, that the argument as such - that moral hazard can provoke suicidal rebellions is problematic. As alluded to earlier, Crawford (2005) proposes that concrete international policy shifts and/or actions which impact a specific state or region are more likely to 
create moral hazard for subjugated groups in that region, especially when they exemplify humanitarian intervention.

First, the data on conflict since the end of the Cold War seems to contradict Kuperman's argument that the norm increases the likelihood of suicidal rebellion. Empirical findings suggest a dramatic decline in the number of wars, genocides and human rights abuses over the past two decades (Human Security Report 2005). In fact, the first Human Security Report (2005) contends that the single most compelling explanation for this trend is the unprecedented upsurge in international humanitarian activism spearheaded by the UN. The broad decline in conflict does not necessarily challenge Kuperman's findings, as conflict caused by moral hazard could increase amidst a general decline. The Report's findings regarding the cause of this decline do, however.

Second, the norm of international intervention is a vague, all-encompassing concept. It arguably shifts the incentives of rebels everywhere and at all times, yet its movers are difficult to identify specifically ("international community"). Variation in the norm is difficult to measure, implying that any variation of moral hazard would be difficult to attribute to the norm. This causal variable, therefore, is unlikely to explain the timing of specific rebellions.

Referring to the work of Bernard (1972) and Lebow (1981), Crawford argues that the norm is, at best, a "remote" cause of war (a long term cause of tension and conflict). "It is a broad background condition shaping rather than triggering [rebels'] decisions to use force" (Crawford 2005, 188). Rather, concrete policy shifts or actions by a potential or actual intervenor toward a specific state or region are more likely to be a "proximate" cause of war (actually trigger violent conflict). Such international actions mark a stark shift in the surrounding rebels' strategic context. In addition, the domain of the 
incentive's influence is crisply delineated, rendering the causal relationship between intervenor and rebel more easily measured. The argument rests on the premise that rebel groups are more likely to be influenced by international interventions, or the prospect thereof, in their vicinity than those which take place at a distance (in both time and space). Kuperman acknowledges the validity of this argument (2008a, 52) and his detailed analysis of Kosovo is consistent with this point.

Kuperman's argument would benefit from greater clarity with regard to the independent variable. While he focuses on the norm of humanitarian intervention, the independent variable is the presence of moral hazard: only if rebels expect international intervention will they launch a suicidal rebellion. ${ }^{44}$ The moral hazard of humanitarian intervention can technically be created by a diffuse norm, by specific nearby intervention, or by a combination of both. Yet in the case of the second, data supporting the causal link is likely to be more compelling (Crawford 2005, 184, 187). In addition, such actions can explain not only the occurrence, but also the timing of a rebellion given that variation in the independent variable is easily identified. These international actions need not be "humanitarian" per se to create a moral hazard for rebel groups. Nevertheless, they are more likely to trigger suicidal rebellions when they are imbedded in the norm's rhetoric as the expectation among surrounding rebel groups that a humanitarian catastrophe will provoke intervention would be greatest. Greater clarity in this regard would address Western's (2005) empirical critique regarding the causal relationship between the norm of humanitarian intervention and the 1992 rebellion in Bosnia.

Crawford (2005) and Western's (2005) criticisms are relevant as they question the empirical foundations of Kuperman's framework. Greater attention should be devoted to

\footnotetext{
44 Moral hazard is posited as a necessary but not a sufficient condition for suicidal rebellion.
} 
specifying the scope conditions in which moral hazard is likely to be present, which Kuperman acknowledges (2008a, 55). Kuperman's case-studies are selected on the dependent variable, which is also true for this research. The theory of moral hazard would benefit from an analysis of multiple case-studies selected on the independent variable (presence of moral hazard), especially in cases where moral hazard appears to be present but suicidal rebellions have not occurred. ${ }^{45}$ These criticisms undermine neither the logical model nor the validity of testing the argument in a specific case-study. The hypothesis remains intuitively plausible in the case of Darfur and policy relevant for the study of international affairs.

\section{Conclusion}

"At the end of the day," argued Gareth Evans, "the case for [humanitarian intervention] rests simply on our common humanity: the impossibility of ignoring the cries of pain and distress of our fellow human beings" (Evans 2007). Since the end of the Cold War, compelling statements such as this one have sought to persuade and/or justify international intervention in states where gross abuses of human rights, including genocidal violence, are ongoing. Such rhetoric and actions by the international community can create a moral hazard. That is to say, they can alter the strategic context in which certain actors make decisions, notably rebel movements. Crawford (2005) compellingly argues that specific interventions by identifiable actors are most likely to alter the strategic environment of nearby rebel groups. Rebel leaders could be enticed to act fraudulently (intentionally provoke a humanitarian catastrophe in order to garner

\footnotetext{
${ }^{45}$ Western highlights one interesting case: on Christmas day 1992 the Bush (41) administration explicitly warned Belgrade that the USA would be prepared to use military force if Milosevic took military action in Kosovo, yet the Kosovo Albanians did not rebel as a result $(2005,234)$.
} 
international assistance) or simply act irresponsibly (take greater risks when they rebel). The likelihood of rebel groups instigating suicidal rebellions against a militarily superior state thus increases, as does the likelihood of genocidal violence. This outcome is perverse (and counterintuitive) as the objective of international humanitarian intervention is to accomplish the opposite. 


\section{CHAPTER 5: THE EVIDENCE}

\section{Introduction}

Based on the information presented so far, it appears likely that Kuperman's theory of the moral hazard of humanitarian intervention sheds light on both the occurrence and timing of the rebellion in Darfur. The scope conditions appear to be met and the international community's involvement in the north-south peace negotiations appears likely to have led the Darfuri rebels to believe these international actors would intervene to their benefit should genocidal violence occur in Darfur. Reflecting the points raised by Western (2005) and Crawford (2005), in this chapter I will formulate, operationalize and test Kuperman's hypothesis as it applies to this conflict. I have chosen to examine whether the rebels acted "fraudulently"; my analysis will nevertheless shed light on the explanatory power of the theory as a whole, as it applies to Darfur. The latter rests on the strength of the evidence with which I examine the hypothesis. As detailed in Chapter 3, my findings are tentative given the difficult circumstances in which the information was collected and my reliance on a relatively small number of key-informants. First, I will highlight the evidence supporting the hypothesis; second I will detail the available information that undermines it.

\section{The Hypothesis}

In early 2003, the Sudan Liberation Army/Movement launched a rebellion against the government of Sudan in Darfur with little apparent chance of success and at great risk to themselves and their civilian support base. I will test the following hypothesis: international humanitarian intervention created a moral hazard that altered the strategic 
incentives of the Sudan Liberation Army/Movement. As a result, the rebel group's leaders intentionally launched a suicidal rebellion against the government of Sudan in early 2003 because they believed international humanitarian intervention would enable victory at tolerable cost.

\section{Testing the Hypothesis}

I will test the hypothesis by assessing whether the evidence I have gathered corroborates its implicit assumptions and predictions (Table 2). Unless indicated as "likely", these criteria are "necessary"; if corroborated with evidence and taken together, they are sufficient to suggest moral hazard played a determining role in the onset of the conflict.

\section{Table 2: The model's assumptions and predictions}

\section{Moral hazard:}

1. An international policy change is likely to have occurred nearby/recently; it was not intended to provoke rebellion or genocidal violence in Darfur, and these outcomes are harmful to the interests of the international actors who authored the policy change;

2. The rebel leaders were aware of the principles and norm of international humanitarian intervention. In addition, they expected the international community to intervene to their benefit should genocidal violence occur;

3. The rebels likely developed the ability to communicate with the international community ahead of instigating conflict and did so vigorously once the conflict was ongoing.

\section{Suicidal rebellion:}

4. The leaders controlled the military actions of their forces;

5. Violence was initiated by the rebel forces against government of Sudan installations.

6. The rebels did not believe they could, or could develop the abilities to achieve their political objectives on their own at tolerable cost;

7. The leadership expected the government of Sudan to retaliate with genocidal retaliation against their civilian support base; they accepted this as tolerable cost.

First, given the evidence presented by Crawford (2005) and Western (2005), a shift

in international policy which had a direct impact on the strategic calculations of the rebel leaders in Darfur is likely to have taken place prior to the rebellion. For moral hazard to 
exist, the direct and indirect consequences that the hypothesis attributes to this policy change must be both unintended and perverse for the international actors in question.

Second, evidence should suggest that the SLA leaders were aware of the international norm and discourse on intervention in states where gross violations of human rights, crimes against humanity and genocide are ongoing. Furthermore, evidence should suggest they expected international intervention to take place in the occurrence of genocidal violence. The recent international involvement in the north-south conflict would have created - or heightened - this expectation. The SLA would likely have expected the intervention to halt the genocidal violence and directly assist the rebels in achieving their political objectives.

Third, if international intervention was to enable SLA victory at tolerable cost, then the international community must necessarily have been aware of their cause, the scale and details of the humanitarian catastrophe and their need for international support. A humanitarian catastrophe of great proportions was likely to generate international NGO and media attention on its own. Yet if this was the rebel leaders' deliberate, premeditated strategy, they are likely to have devoted time and resources to ensuring the relevant international actors were aware of the crisis using both direct contact with diplomats and international media. This is especially likely given the civilian lives at stake. In reference to the international media, Bob (2001) argues that subjugated groups must confront the indifference of international audiences and scarce attention, sympathy and resources of media outlets. In addition, Darfur is difficult for international media to access due to its remoteness and the oppressive state apparatus. The rebels would likely have developed communications capacities before instigating the conflict, and aggressively used these at the onset of the conflict. It is reasonable to assume that the rebels would have mimicked 
the international discourse on human rights, state responsibility, and international humanitarian intervention.

Fourth, in addition, if the rebellion was suicidal, then evidence should suggest the rebel leaders controlled the military actions of their forces at the onset of the conflict. The rebel attacks against the government of Sudan must have been the outcome of the leaders' decision to attack the government. If evidence suggests that the rebel leaders did not control the military actions of their forces at the onset of the conflict, then the attacks cannot be traced back to the rebel leaders' strategic intentions and the hypothesis would not shed light on the puzzle.

Fifth, central to the definition of a suicidal rebellion is the fact that violence was initiated by the rebel group, not by the government, with the intention of instigating a rebellion. Evidence should suggest that the rebel attacks on government installations were not in direct response to past state-sponsored violence nor motivated by self-defence. If they were, Kuperman's hypothesis about the rebels' strategic intentions is unlikely to explain why the rebels attacked the government of Sudan when they did. Given that low intensity conflict had existed for generations in Darfur and had been increasing in the decade prior to the rebellion, the rebellion must therefore mark a clear break in Darfur's history.

Taking into account the SLA's objectives of extracting wealth and power from Khartoum and improving security in Darfur, the hypothesis predicts the rebels would attack the government (police stations and military installations), not Arab militias or tribal defence forces. The government was directly responsible for the distribution of power and wealth in Sudan, and indirectly responsible for security, or the lack thereof. Attacking the state would be an act of political rebellion and, therefore, more likely to 
garner the attention of the Sudanese state apparatus, credibly communicate their political demands and provoke retaliation. This would allow the rebels to more easily frame the conflict in terms of a state/perpetrator and rebels/victims dynamic, and international humanitarian intervention would have been more likely to include pressure on the Sudanese government to address the grievances of the rebels.

Six, information should also indicate that the rebel leaders did not believe they could achieve, or could develop the abilities to achieve, their political objectives on their own. Doing so would likely require the ability to threaten Khartoum or the country's resourcebase, the oil fields. Had they believed they could achieve their objectives on their own, there would have been no need to risk/sacrifice the lives of their civilian support base in the hope of garnering help from the international community. Evidence should suggest the rebels would not have rebelled had they not expected international intervention, and did rebel because they did expect international intervention.

Finally, seven, for the rebellion to be described as suicidal, evidence should also indicate that the rebel leaders expected the government of Sudan to respond to their attacks by targeting the rebels' civilian support base with genocidal violence. The rebels' "civilian support base" would include civilians from tribes which were associated with the rebellion, primarily the Fur, Zaghawa and Masalit. Implicit in this assumption is that the rebel leaders did not believe they had the ability to prevent or stop the anticipated retaliation against civilians and accepted ahead of instigating conflict significant civilian casualties.

In terms of the timing of the rebellion, Kuperman's theory predicts that the existence of moral hazard is a necessary prerequisite for this causal mechanism to be triggered, which, in this case, is likely to have been created by the international involvement in the 
north-south peace process. Once moral hazard present, the rebels would have started the rebellion when they believed they possessed enough military capabilities to maintain sustained engagement (not be immediately annihilated by the government of Sudan) and were able to communicate details of the humanitarian catastrophe to the international community effectively.

In sum, if this hypothesis explains empirical puzzle of Darfur, then evidence should demonstrate that the international community's policies and actions created a moral hazard and that the rebellion was suicidal. I have gathered material which provides detailed pictures of both the north-south peace negotiations as well as the onset of the conflict. I will examine whether international involvement in the north-south conflict created a moral hazard that altered the strategic incentives of the SLA; and whether, as a result, the rebel group's leaders initiated conflict against the government to provoke violence against civilians because they believed international humanitarian intervention would enable victory at tolerable cost. I will do so by verifying whether evidence supports the hypothesis' assumptions and predictions (Table 2).

\section{Evidence supporting the hypothesis}

Testing the hypothesis with the available empirical evidence reveals that the SLA's behavior initially appears to have been fraudulent. First, there is evidence that the international community involuntarily created a moral hazard which altered the strategic incentives of the SLA: the group's leaders were aware of the international discourse on international intervention, sought some international support before the rebellion and did expect the international actors involved in the north-south peace talks to intervene to their benefit. The SLA also informed these actors of its intention to launch a rebellion before 
doing so. In addition, some evidence suggests the rebellion in Darfur and the resulting genocidal violence were harmful to the interests of the international actors involved in the north-south peace negotiations, the second criteria of moral hazard.

Second, the information on hand appears to indicate the rebellion was suicidal: the rebels intentionally launched the rebellion in early 2003 and the government's reaction appears to have been predictable.

\subsection{Moral hazard: Awareness of the norm of international humanitarian intervention}

Evidence suggests that, prior to the instigation of rebellion in Darfur, the SLA leaders were aware of the key role the international community played in the north-south peace negotiations and understood the former to exemplify the broader norm of international humanitarian intervention. In addition, they expected the international community to intervene and believed such an intervention would benefit them. Therefore, it appears reasonable to infer that international involvement in the region impacted the strategic calculations of the Darfuri rebel leaders.

The SLA leaders were aware of the international community's role in the Naivasha talks. On 23 October 2003, SLA leader Mini Minawi told Agence France Press that the government was "negotiating with the south because of pressure from the international community and military pressure in the south, in the west and in the east of Sudan" (AFP 2003). While this statement was made well after the onset of the conflict in Darfur, evidence suggests the rebels were aware of the international community's involvement in the north-south conflict before they launched rebellion. As noted in Chapter 2, the unprecedented nature of the peace talks between the SPLA and the government meant 
they generated widespread attention in Sudanese national media. The international community's involvement in these was widely reported (LexisNexis online database). ${ }^{46}$ The Darfuri rebels would also have learned details of the international involvement in the negotiations from the SPLA, by whom they were coached at the onset of the conflict. Edward Leno, the head of intelligence of the SPLA, was the SPLA's main contact with the SLA. He stated: "the leaderships did a lot of work together," both before and after the beginning of the conflict (Edward Leno: personal interview, August 2007). He spoke, in particular, of the SPLA's assistance in drafting the SLA's Political Declaration in December 2002 and January 2003 (see also Flint 2007), while the north-south talks were ongoing.

The SLA's awareness of the broader international norm of humanitarian intervention is evident in their political manifesto released on 14 March 2003. The following passages are particularly noteworthy:

The monopolization of power and wealth led to the institutionalization of the hegemonic policies of riverine Sudan's dominating establishment. These policies have resulted in massive human rights violations amounting to ethnic cleansing and genocide in certain areas of all the three states of Darfur. The brutal oppression, ethnic cleansing and genocide sponsored by the Khartoum Government left the people of Darfur with no other option but to resort to popular political and military resistance for purposes of survival. (SLA/M 2003,1-2)

Finally, on behalf of the people of Darfur, we appeal to the international community to assist the people of Darfur with humanitarian relief to address and ameliorate the serious and deteriorating humanitarian situation in the Region. Ethnic cleansing and other gross acts of genocide sponsored by the Khartoum regime have caused massive displacement and suffering in all the three states of Darfur. This has been further compounded by draught and desertification. The population is in dire need of food, human medicine, animal drugs and other non-food services. (SLA/M 2003, 5)

The SLM/A shall struggle for the full realization and respect for human rights and democratic pluralism in accordance with international standards leading to equal development and the eradication of political and economic marginalization. (SLA/M 2003, 2)

\footnotetext{
${ }^{46}$ LexisNexis Academic media database turns up 134 publications for the following search: Source: Major World Publications; search terms: "BBC Monitoring: International Reports" and "Sudan" and "negotiations" and ("international community" or "IGAD" or "United States"), date: (between) 1 April 2002 and 26 February 2003. The vast majority of the articles are published in Sudanese media.
} 
The declaration is eloquently drafted and clearly mimics the international discourse on human rights and international humanitarian intervention: "massive human rights violations," "ethnic cleansing," "genocide," "international community," "humanitarian relief," "deteriorating humanitarian situation," "respect for human rights," "international standards". The rebels explicitly accuse the government of committing genocide and call on the international community to send humanitarian assistance to Darfur. This demonstrates an awareness and understanding of the concept of international humanitarian intervention, as defined in Chapter 4, and a desire for it, notably in the form of humanitarian assistance.

The rebels requested further intervention in the form of a negotiations framework. From 24 to 26 February 2003, the government of Sudan organized a Darfuri leadership conference with tribal and political elites from across Darfur in order to seek the local leaders' blessing to squash the rebellion militarily (ICG 2004, 12). However, the tribal leaders insisted on a political solution. The government acquiesced to sending tribal negotiating teams to the rebel strong-hold. A delegation of six Fur elders traveled to the Jabel Marra and met with SLA leaders on behalf of the government on 16-18 March. Ablagasim Seif Eldeen headed the delegation and Mohamed Baraka was a member, both of whom I interviewed in 2007. Baraka reported the rebels demanded an equitable distribution of wealth and power in Sudan, with an emphasis on greater development and security in Darfur. In addition, he said: "they stated they wanted their problems solved by the United Nations; they would not go to any negotiations without this condition" (personal interview, August 2007). Essentially, the Darfuri rebels were requesting the international community sponsor peace negotiations similar to the north-south talks which were ongoing in Kenya. 
The rebels would have had reason to believe international involvement in the conflict in Darfur would improve their chances of success. Kenny, a Canadian expert on Sudan, argues:

The lesson of those 15 years [since the ruling party came to power in 1989], however is that when the Government has been the target of serious pressure with a specific objective, it has modified its behaviour. It is a pragmatic regime that will do what it has to in order to survive, including choosing cooperation rather than attempting to impose unilateral solutions. (2004)

Prendergast (2007) provides concrete examples. In addition to playing a key role in bringing the southern rebels and the government to the negotiating table, he argues international pressure changed Sudanese policy on two major issues: its support for terrorist organizations (notably Al Qaida) and slavery.

Not only were the rebels aware of "international humanitarian intervention", the specific role of the international community at the Naivasha talks and had they requested help from the international community, some rebels expected intervention. Five respondents who were in touch with the rebel leaders in 2003 stated that the latter did expect the international community to intervene diplomatically to pressure the government of Sudan to halt military aggression in Darfur and negotiate with the rebels; they also expected humanitarian assistance (Ablagasim Seif Eldeen, Mohamed Baraka, Phil Cox, Bashura Hassan el-Taher, Respondent 32: personal interviews, July and August 2007). In particular, Ablagasim Seif Eldeen, the senior Darfuri parliamentarian who headed the delegation that negotiated with the rebels, who is also the father-in-law of Abdelwahid (leader of the SLA at the onset of the conflict), stated: "the European and American discourse on human rights did create some expectation of intervention amongst the rebels and other Darfuris" (personal interview, July 2007). Respondent 32 is a Fur in his late 20s who came to the United Kingdom as a refugee in 2001. He left Darfur after 
his father was killed by Arab militias in 1999. Despite his efforts while still in Darfur to seek justice for his loss, the authorities remained indifferent to the crimes and the perpetrators roamed free. Before and at the onset of the conflict, as I will detail below, he was active in gaining international support for the rebellion. In conversation on 15 August 2007 , he stated that "he thought the international community would put pressure on the government of Sudan to halt the atrocities" (personal interview, August 2007).

Therefore, information I collected through in-person interviews, which is supported by official SLA documents and research undertaken by Darfur scholars, suggests the SLA leaders expected the international community to intervene to their benefit should rebellion be sparked. They expected intervention to take place in the form of humanitarian assistance, as well as political pressure on the government to halt the violence and negotiate a power and wealth sharing agreement with the rebels and put an end to the violence. The international community, therefore, appears to have influenced the strategic calculations of the SLA.

\subsection{Moral hazard: Intention to communicate with international actors}

This research seeks to explore whether the SLA rebels intentionally provoked a humanitarian catastrophe to garner international intervention, in order to advance their political objectives. This would have been a conniving premeditated strategy. It is possible the rebels would have believed international NGOs and media would automatically stir-up international interest in a humanitarian catastrophe, ensuring international intervention. Nevertheless, it is likely (although not necessary) that a central component of their strategy was a plan to communicate with the international community. Two communication routes were possible, and one would expect both would have been 
used: direct communication with the diplomatic community and use of the western media to create a "CNN effect". The concept refers to the emergence of the 24-hour news media and its ability to shape foreign policy. Some policy makers, journalists, and scholars have argued that the constant news cycle, in particular the projection of images of humanitarian crises, has created a powerful imperative for Western policy makers to intervene in these situations (past examples are arguably Iraq (1991), Bosnia, Somalia, Rwanda and Chechnya) (Gilboa 2005). The concept has come under some criticism (Western 2002; Gilboa 2005), and Olsen, Carstensen and Hoyen (2002) present methodologically sound evidence that only occasionally does the media play a decisive role in inflating the volume of emergency aid. ${ }^{47}$ Nevertheless, it remains likely that the SLA would have built a communications capacity and strategy ahead of the rebellion, and unleashed it at the onset of the conflict.

Several participants involved in the rebellion stated they recognized the importance of communicating details of the situation in Darfur to the international community, through both the media and diplomatic channels. Mohamed Baraka, an elected member of the National Assembly heavily involved in promoting the cause of Darfur, both in Sudan and abroad, stated that he met with American and British diplomats in Khartoum before the start of the insurrection (personal interview, August 2007). He informed them of the long-standing marginalization of Darfur, the rising insecurity in the region and the emergence of armed movements with political objectives. Elizabeth Hodgkin, a senior officer at Amnesty International (AI) and Sudan expert, and Benedict Goderia, her junior colleague, both of whom met with SLA leaders in Darfur on an investigative mission for

\footnotetext{
${ }^{47}$ Rather, the security interests of Western donors and the strength of the humanitarian apparatus (NGOs and international organizations) are more influential (Olsen et al. 2002). While international emergency dollars and "international intervention" are not synonymous, the analysis provides a helpful indicator.
} 
AI in January 2003, confirmed hearing of these meetings (personal interview, August 2007). Bashura Hassan el-Taher stated that "the movement tried to bring the issues in Darfur to the attention of international actors" and link them to the grievances of the SPLA at the Naivasha peace talks (personal interview, August 2007). He is a mid-level SLA leader who participated in planning the rebellion and in the SLA's interface with international actors since the conflict's onset. Peter Schumann, the former Regional Coordinator and Representative of the UNMIS in Southern Sudan, confirmed: "the rebels made clear statements to the international community before launching the rebellion" (personal interview, April 2008).

The rebels also made some efforts to communicate details of the situation in Darfur to Western media and non-governmental organizations (NGOs) before the onset of the conflict, both of which can play a role in generating international attention for a particular humanitarian crisis (Bob 2001). Respondent 32 had been working in the United Kingdom since 2001 on procuring arms and financial support for the rebellion, as well as on generating political and media interest in Darfur (personal interview, August 2007). He spoke of doing one interview for Channel 4 News in 2000-2001 and of establishing links with Amnesty International ahead of the conflict. Phil Cox, a British filmmaker who was the first Western video-journalist to travel clandestinely to Darfur in late 2003 (with Respondent 32), corroborated this information (personal interview, August 2007).

Evidence also indicates the rebels made some efforts to communicate information on the humanitarian situation to the international community at the beginning of the conflict. In fact, three Western respondents stated that they coached the rebel leaders on the importance of documenting the conflict and communicating the atrocities to the international media and diplomatic community. "They sought advice from me on what 
they should do," said Cox, who has since directed a feature film on the conflict in Darfur entitled "Children of Darfur" (personal interview, August 2007). He stated that he made explicit the link between media attention on the crisis, international awareness of the humanitarian catastrophe and international humanitarian intervention, underlining the importance of images in garnering Western diplomatic attention. Elizabeth Hodgkin and Benedict Goderia, from Amnesty International (AI), also highlighted the importance of documenting atrocities committed in Darfur and communicating these to international organizations (personal interview, August 2007). Mohamed Baraka, the Darfuri parliamentarian who met with international diplomats ahead of the conflict, confirmed the rebels received this advice (personal interview, August 2007). He recounted one episode in which he smuggled photos of a government attack on the town on Shoba (25 June 2003) to London, and communicated the details of the attack to AI. These were documented in AI's press release on 30 June 2003 (AI 2003). Finally, as outlined above, the rebels communicated information on the suffering of Darfuris and their need for international assistance in their Political Declaration of 14 March 2003 (SLA/M 2003).

While evidence of rebel communication with the international community is not a necessary condition for this hypothesis, it is likely. The information detailed above indicates that that some efforts were made by the rebel leadership and by Darfuri elites sympathetic to the rebellion to raise international awareness of the evolving situation in Darfur. Some evidence also suggests efforts were made to broadcast the humanitarian crises, the details of the rebellion, and their need for international intervention, to the world via non-governmental organizations and media once the rebellion was in full-swing (in 2003). 


\subsection{Moral hazard: The rebellion was perverse for and unintended by the international community}

For moral hazard to exist, not only must the international community (or specific international actors) have influenced the behaviour of the SLA rebels, but SLA actions (and the indirect consequences of these actions) must be harmful to the interests of the international community. Evidence detailed below suggests that both the rebellion and the resulting genocidal violence were harmful to the interests and unintended by the international actors involved in the north-south peace negotiations.

In the eyes of Darfuri rebel leaders, the potential intervenors in Darfur were the major Western actors involved in the north-south peace negotiations: primarily the United States, the United Kingdom, the United Nations and the European Union. These actors embodied the "international community," and their priority at the time was north-south peace (ICG 2004, i). The conflict had raged for over twenty years, devastating the lives of south Sudanese and destabilizing the region. The international community was caught in a difficult position: it feared the rebellion in Darfur would destabilize the north-south talks and ruin the unique opportunity for peace (Anderson 2004; Slim 2004; Weismann 2007; Reeves 2009). Ibrahim Ahmed Ibrahim, the SLA spokesperson in London, stated: "in 2003, the international community sent a message to the rebels saying the European Union and United States would not help them as they were busy with the south" (personal interview, July 2007). Abdalla Adam Khatir, a Darfuri journalist based in Khartoum, and Peter Schumann, a former senior UN official in Sudan with extensive experience in the country, both suggested the international community was very annoyed with the Darfuri rebel movements. The former had heard that the Americans told the Sudanese government that if it could squash the insurgency quickly, it should do so (personal 
interview, July 2007). Schumann suggested something very similar: "the British and the Americans clearly indicated to the National Congress Party [the governing party in Sudan] that if they moved quickly on the Comprehensive Peace Agreement with the SPLA, Darfur would be considered 'in their own backyard"' (personal interview, April 2008). This suggests the international community expected a rebellion in Darfur was harmful to its interests. The timeline of the conflict also suggests the rebellion was unforeseen by relevant international actors: it is only after the American government exerted significant pressure on the parties to the north-south conflict that the Darfur rebellion was launched.

The information detailed above also indicates that international actors did not anticipate, and therefore did not intend, the government's use of genocidal violence (indirect outcome) or the ensuing humanitarian catastrophe. Their hope - and belief - was that rebellion in Darfur would fade away and not disrupt the north-south negotiations (Peter Schumann: personal interview, April 2008). The occurrence of conflict and genocidal counter-insurgency has jeopardized the implementation of the CPA, gobbled up limited international resources available to humanitarian crises, monopolized national and international public servants' time and energy, strained some global alliances (notably between the West and both the Arab world and China) and has shamed prominent national governments and international institutions for their inability to respond effectively to the crisis. The credibility of these actors has been sullied by this crisis.

Therefore, information collected during in-person interviews and reinforced by expert opinion compellingly suggests the rebellion and ensuing genocidal violence in Darfur were harmful to and unintended by the actors involved in the Naivasha talks, essentially, the "international community". When coupled with the suggestion that the 
rebels' strategic calculations were influenced by the policies and actions of the international community, moral hazard appears to have been present.

\subsection{Suicidal rebellion: Rebels intentionally instigated rebellion}

On 26 April 2003, one day after the rebel attack on el-Fashir Airport, Sudanese army spokesman Major-General Muhammad Bashir Suleiman characterized the attack as a "suicide attempt" in Sudanese media (Ahmad al-Nur, al-Shaykh al-Salik and Daw-alNa'im 2003). For the conflict in Darfur to have been a suicidal rebellion, the rebel attacks that launched the conflict must have been on direct orders from the rebel leadership; the rebels must also have initiated the violence. The intention must have been to sustain military engagement until violence was provoked against civilians: the rebellion would therefore appear to be "full-scale". The fractious nature of the SLA leadership and its weak command and control structure has been well documented (Tanner and Tubiana 2007, 25-30; Flint and de Waal 2005, 85-87). Several participants whom I interviewed, including individuals close to the rebel leadership and international experts, echoed these findings. Despite this, as I will specify below, there is strong evidence to support the claim that the leadership controlled its forces at the onset of the conflict and attacked the government in order to deliberately instigate a rebellion. These claims are consistent with the hypothesis.

Contemporaneous media accounts and English language publications referenced throughout this work describe the rebel attacks that instigated conflict in Darfur similarly. ${ }^{48}$ These accounts are consistent with the interviews I conducted. The rebel

\footnotetext{
${ }^{48}$ Including but not limited to: Flint and De Waal (2005), Prunier (2005), Burr and Collins (2007), Daly (2007), de Waal (2007) and Tanner and Tubiana (2007).
} 
forces are said to have skillfully targeted government installations; they did not target ethnic Arab militias and avoided civilian casualties. This behaviour is evidence of a strong command structure. This is all the more true given some of the recruitment methods of the SLA. One key informant I interviewed suggested the rebel leaders recruited fighters to the SLA by telling them the movement was a self-defence militia intended to protect "African tribes" (Fur, Zaghawa and Masalit) from the increasingly aggressive Arab militias. Bashura Hassan el-Taher, a mid-level SLA leader who was active in the planning and participated, notably, in the major attacks on government forces in early 2003, stated: "while the commanders knew that it was a political movement, the soldiers did not know. They thought it was just a tribal affair" (personal interview, August 2007). The SLA leaders are said to have done so for two reasons: word of a political rebellion would have reached the government of Sudan before the rebel movement was ready and compromised their plans, whereas ethnic conflict was of little interest to the government. Secondly, fighters were initially reluctant to launch a rebellion against a far off government, which was not a direct threat to their lives and livelihoods. Therefore, had the leadership not controlled their forces, the forces would have targeted Arab militias which were a direct threat to their safety and livelihoods, not police stations and other government symbols. The fact that the first attacks skillfully targeted government of Sudan installations is strong evidence the leadership controlled its forces; it is therefore likely the rebel attacks on government installations were the result of a deliberate decision by the rebel leaders.

It is also fair to assert that the rebellion in Darfur was instigated by the rebel movements, not the government of Sudan. This point is crucial to the hypothesis as the puzzle of a "suicidal rebellion" rests on the victim party deliberately choosing a path that 
is likely to harm them and their supporters. If the rebels acted in self-defence or retaliation, rational deterrence theory predicts that deterrence failed because the rebels "expected victimization anyway", and so had nothing to lose (Table 1). As a result, the hypothesis of moral hazard of humanitarian intervention would be unlikely to explain the rebellion in Darfur. The history of conflict in the region is long and complex. Most tribes have, at one point or another, taken up arms against each other; the government has often taken sides; violence in the name of self-defence and in retaliation for past violence was becoming rife, especially since the disintegration of peaceful conflict-resolution mechanisms (de Waal 2007, 35; Tanner and Tubiana 2007). Flint and de Waal contend that by the time the Darfuri rebel movements launched attacks on government targets in early 2003, parts of Darfur had been in open war for several years $(2005,76$; see also ICG 2004). Indeed, in 2001 and 2002, government-backed Arab militia attacks on non-Arab communities increased, especially around Jebel Marra (against the Fur) and against the Zaghawa tribe (Tanner and Tubania 2007, 14). Identifying the "first mover" of conflict in 2003 is therefore difficult.

The qualitative data does suggest that questions of self-defence motivated the attacks that triggered conflict in Darfur, which could undermine the hypothesis. First, the rebels' decision to attack el-Fashir airport can be construed as a defensive tactical move. The rebels had reasons to believe the Sudanese Air Force would bomb the rebel camps; the rebel leaders attacked the airport on 25 April 2003 to stop the government from doing so, stated Bashura Hassan el-Taher and Respondent 21, the fist a mid-level SLA leader who participated in the attack on el-Fashir airport and the second an SLA fighter (personal interviews, August 2007). But the government planes were stationed at el-Fashir airport in order to bomb a rebel force that had already attacked government installations (notably 
Golo in February 2003) and publicly advertised their political demands (on 14 March 2003, SLA/M 2003). The government's plan to bomb them was, therefore, itself a defensive move. While the rebels did not choose the date of the attack that thrust this conflict onto the national and international agendas - and which ultimately provoked genocidal violence - the decision to choose conflict as a means to their political ends was theirs.

Elsewhere, the rebels publicly argue that broader themes of self-defence and the politics of retaliation account for the rebellion. ${ }^{49}$ In their political declaration, the SLA claim the movement "originated from Darfur as a matter of necessity in response to the brutal genocidal policies of the [ruling] Government in that region" (SLA/M 2003, 2). This justification was endorsed by many of the respondents I interviewed. Yet attacking government installations is not an effective means of protecting civilians from "brutal genocidal policies"; quite the contrary in fact. Pervasive insecurity and unfair distribution of wealth are well documented in Darfur, but they do not undermine the claim that the rebels' strategy and tactics were offensive. While acknowledging the complex and longstanding nature of conflict in Darfur, evidence supports the claim that SLA leaders deliberately chose to attack the government of Sudan in 2003 with the objective of provoking a full-scale rebellion, which supports the hypothesis of a suicidal rebellion.

\subsection{Suicidal rebellion: Genocidal retaliation was predictable}

With much exasperation, Respondent 11, a female south Sudanese academic, human rights practitioner and former SPLA sympathizer stated on 18 July 2007:

\footnotetext{
${ }^{49}$ See literature review, Chapter 2, "No other choice".
} 
Darfuris keep launching unprepared attacks. Bolad instigated rebellion in 1991 entirely unprepared, and was captured and killed by the government. This conflict was launched before the SLA was strong. The government took advantage of this unpreparedness and created great confusion. (Personal interview, July 2007)

The question is: did the Darfuris do so intentionally in 2003 "because international support forms more easily around issues involving a threat to physical integrity" (Belloni $2006,334)$ ? Central to the definition of a suicidal rebellion is the rebel leaders' expectation that their actions will provoke harmful consequences for themselves and their supporters. Therefore, the SLA leaders must have expected genocidal retaliation ahead of launching the rebellion, and accepted this as "tolerable cost" for achieving their political objectives. Some information indicates this was indeed true.

Before the SLA initiated armed conflict, on at least two occasions, the government warned the Darfuri rebels not to follow the path of southern rebels. As mentioned above, Prunier (2005) and Flint and de Waal (2005) report that Ali Osman Taha traveled to Darfur in early November 2002 and gave a well attended speech. Later, at the Darfuri Leadership Conference in February 2003, presidential advisor Nafi al-Nafie accused the rebels of fomenting conflict in the hopes of being granted a negotiation process similar to the north-south process. He warned Darfuris that this was not a realistic objective and that they actions would bring dire consequences (Mohamed Baraka: personal interview, August 2007). The rebels disregarded these warnings.

As detailed in Chapter 2, the major turning point for the government was the humiliating rebel attack on the el-Fashir airport which destroyed several planes, killed soldiers and captured the garrison commander. "After that," said Abdalla Adam Khatir, a renowned Darfuri journalist and member of the National Democratic Alliance," "the

${ }^{50}$ An umbrella political opposition movement (ICG 2004). 
government wanted to evacuate the whole region so that the rebels had no support. They believed the villages were the real camps; the government bombed and the Janjaweed destroyed afterwards" (personal interview, August 2007). A major humanitarian catastrophe ensued which captured the attention of the international community. On 9 December 2003, UN Secretary General Kofi Annan stated that he was "alarmed at the rapidly deteriorating humanitarian situation in the Darfur region of the Sudan, and by reports of widespread abuses against civilians, including killings, rape and the burning and looting of entire villages" (UN Secretary General 2003).

On 31 August 2007, I conducted a three-hour interview with Dr. Hassan al-Turabi, one of the most influential men in Sudan, as described in Chapter 2. During the interview he argued that the rebels should have anticipated that the government of Sudan would respond to the rebellion by targeting civilians via proxy-militia forces (personal interview, August 2007). Turabi elaborated at length on the mindset of the Sudanese military leaders, arguing they only knew how to respond militarily; only when their military response failed did they seriously consider negotiating with their opponent (see also Kamal el-Din 2007). He then described the government's lack of military alternatives: eighty percent of the rank and file in the Sudanese army was Darfuri, who have questionable loyalty to Khartoum (see also Prunier 2005, 97). The rebels acknowledge this in their political manifesto: "we appeal to our brothers in the regime's armed forces to abandon the regime and join us, or if it is not possible to join us, not to fight us" (SLA/M 2003, 4). Turabi then described how the army had trained the Popular Defence Forces and the Janjaweed, whom he characterized as "wild people". "Essentially, the government had no other choice," he concluded.

The SPLA, who had fought the Sudanese government for over twenty years, agreed 
with this assessment. Edward Leno, the senior SPLA leader who coached the SLA prior to the instigation of the rebellion, stated: "the government's use of the Janjaweed and their attacks on civilians was predictable. The rebels should have known" (personal interview, August 2007). In response to my query as to how he would have reacted to the rebellion in Darfur had he been in the government's shoes, he admitted that he would have done as they did: he would have mobilized ethnic militias against the rebels and their civilian support base. With a touch of sarcasm, he added that, unfortunately, his contacts in the Sahel were not as good as the government's: he would not have been able to bring in Arab tribes from across the desert to repopulate the land off which the Fur, Zaghawa and Masalit were being chased. Ibrahim Ahmed Ibrahim, the SLA spokesperson in London, echoed the allegation of repopulating non-Arab land with non-Darfuri Arabs, as did Saleh Mahmoud Osman, a prominent Darfuri human rights lawyer (personal interviews, July 2008). In a separate interview, Leno's junior colleague, Respondent 10, also argued that the government's counter-insurgency strategies were the same as those it employed against south Sudanese (personal interview, August 2007).

The evidence points to the fact that the rebels should have known the Sudanese government could not count on the military to squash the rebellion and would therefore respond to their attacks with the Janjaweed militias. They should have known these militias would target civilians and provoke a humanitarian catastrophe. In addition, attacking the government could only have made the humanitarian crisis - which they themselves reference in their Political Declaration (SLA/M 2003, 5) - worse. This suggests the rebel leaders likely predicted the onslaught of violence against civilians. As detailed above, coupled with the fact that they appear to have controlled the actions of their forces, it is reasonable to infer the SLA leaders intentionally chose a path that would 
provoke a humanitarian catastrophe.

\subsection{Conclusion: Evidence supporting the hypothesis}

"The objective of this war is to prove that this is a criminal government. It is working!" said Respondent 9, an educated Darfuri man in his mid-thirties, now working in Khartoum for an international NGO on development projects in Darfur (personal interview: August 2007). The conflict in Darfur is a human tragedy. The government of Sudan has sanctioned and perpetrated violence against civilians in Darfur; it therefore bears responsibility for the tragedy. The International Criminal Court issued, on 4 March 2009, an arrest warrant for President Bashir on charges of war crimes and crimes against humanity in Darfur (ICC 2009). Yet evidence presented here suggests that the rebel leaders who instigated the conflict also bear some responsibility for these crimes, as does the international community. The rebels' responsibility accrues from the fact that they appear to have launched a suicidal rebellion: evidence suggests the SLA rebel leaders intentionally instigated full-scale rebellion against the government of Sudan. They chose to do so in conditions in which genocidal retaliation against their civilian support base was all but inevitable. It therefore appears reasonable to infer that the rebels intentionally provoked a humanitarian catastrophe.

The international community may also bear some responsibility for this humanitarian catastrophe as evidence suggests their actions influenced the decision-making process of the SLA leaders. Information collected from a limited number of interviews with keyrespondents, substantiated by expert practitioner and scholarly accounts, indicates that the international community's involvement in the north-south peace process, which was imbedded in the norm and discourse of international humanitarian intervention, led the 
Darfuri rebels to believe the international community would intervene in Darfur and, possibly, enable rebel victory at tolerable cost. The evidence presented thus far appears to confirm the hypothesis being tested: international humanitarian intervention appears to have created a moral hazard that altered the strategic incentives of the Sudan Liberation Army/Movement. As a result, the rebel leaders appear to have launched a suicidal rebellion against the government of Sudan in early 2003 in order to attract international attention.

\section{Evidence undermining the hypothesis}

However, as I will detail below, further analysis of the accessible empirical information reveals a very different version of the SLA's strategic vision at the onset of the conflict in Darfur. It paints a picture of a rebel force that expected to achieve military victory on its own. This picture undermines the explanatory power of Kuperman's hypothesis. In fact, while limited in quantity, the evidence intimates that the SLA rebel leadership believed they could build the military capabilities to threaten Khartoum. The rebels appear to have believed that the justice of their cause would enable them to achieve such an objective because they expected widespread frustration to lead Darfuris to join the rebellion. The rebel leaders appear to have anticipated their primary opponent would be the Sudanese military, which was weak. While experienced Sudanese leaders argued genocidal retaliation was predictable, further evidence suggests the SLA leaders themselves did not anticipate such retaliation against Darfuri civilians. In fact, the rebels appear to have believed the greatest threat to their success was government-propagated misinformation. Their communication campaign therefore targeted Darfuris and Sudanese. The hypothesis that the insurrection in Darfur was a cunningly calculated 
suicidal rebellion appears to fall. Instead, rebel naïveté seems to have greater explanatory power: the leaders' youth and optimism may have blindly propelled them on a disastrous path.

\subsection{Not a suicidal rebellion: The SLA's strategic vision}

When applied to the onset of the conflict in Darfur, Kuperman's hypothesis of moral hazard of humanitarian intervention assumes that the SLA rebel leaders' strategy was to provoke a humanitarian catastrophe in order to garner international humanitarian intervention, which, they believed, would enable victory at tolerable cost. The hypothesis assumes that victory would come in the form of a politically negotiated power and wealth sharing agreement between the Darfuri rebels and the government of Sudan. Implicit in the hypothesis is the assumption that the SLA leaders did not believe they had the military capabilities to threaten the government on their own; they needed the international community to artificially inflate their strength relative to the government.

Yet evidence of the SLA's strategic objectives, strategy and the leaders' assessment of their military capabilities do not support these assumptions. The leaders appear to have believed they could only achieve their objectives by threatening the government; they knew they needed military strength to do so; and they believed they could achieve this strength. The SLA's strategic objective appears to have been to topple (or seriously threaten) the government in Khartoum. The SLA political declaration reads:

The SLA/M shall struggle [...] to remove the [ruling party's] dictatorial regime and establish a democratic system based on a new political dispensation of freedom, justice, respect for human rights and equality for all Sudanese. (SLA/M 2003, 4)

Bashura Hassan el-Taher, the mid-level SLA leader and deputy of Mini Minawi when I spoke with him in Khartoum, stated: "the SLA's vision was to make the government of 
Sudan collapse" (personal interview, August 2007). Respondent 32, a Darfuri spokesperson in London with links to the SLA, stated: "either the government falls or they make the government negotiate. The government will only do so if the rebels are strong" (personal interview, August 2007). Indeed, the rebels needed to threaten Khartoum.

A key assumption throughout this paper has been that the rebel forces were significantly inferior to the government (ICG 2004, 2; Respondent 35: personal interview, August 2008). Many participants concurred with these scholars and practitioners that the movement had few resources at the beginning of the conflict. The first minor attacks against government outposts in the fall of 2002 were launched with only two vehicles (Bashura Hassan el-Taher: personal interview, August 2007); both SLA and SPLA officers with whom I spoke also confirmed that the SLA leaders were grateful for the meager donations of equipment from the SPLA, notably one satellite telephone (Edward Leno and Bashura Hassan el-Taher: personal interviews, August 2007; see also Tanner and Tubania 2007, 21).

Given the information on the military strength of the government and the Janjaweed forces at its beck, why did the rebels believe they could develop the means to achieve their political objectives on their own? The answer to this lies in the rebel leaders' strategic vision. Bashura Hassan el-Taher, who participated in the attack on the el-Fashir airport, explained how the SLA leadership believed the rebellion would unfold:

The movement focused on the army. We had little equipment, only what we captured from the government [the Sudanese military and police]. Our soldiers, fighters, were well trained though, and the movement was enlarging organically every day. The plan was to spread the conflict to Kordofan, and other regions of Sudan. We expected to make it to Khartoum with our mobile units. (Personal interview, August 2007)

As surprising as this objective may sound, the JEM attack on Khartoum (Omdurman) on 
10 May 2008 lends credence to this claim: approximately 3000 men crossed the desert from Darfur in "technicals" (land-rovers mounted with machine guns) and descended on Khartoum in an attempt to overthrow the government (de Waal 2008).

The rebels relied on capturing weapons from the government, which was relatively easy at the conflict's onset (Bashura Hassan el-Taher and Respondent 21: personal interviews, August 2007). Most importantly though, they believed the "justice of their cause" would guarantee civilian support and recruitment to their force. They assumed that word of their fight for justice and an equitable distribution of wealth would awaken Darfuris to their plight and lead them to take up arms against the government of Sudan. In fact, the rebels predicted correctly, to a certain extent. Dr. Mudawi Ibrahim Adam, a long time political dissident who runs the Khartoum-based development NGO Sudan Social Development Organization (SUDO), described the onset of the conflict:

It was a small group of rebels at the beginning. They only came out with a massive public declaration after their attack on el-Fashir airport. As soon as they did, the movement exploded! Frustrated people from all over Darfur picked up arms and claimed they were part of the SLA. This meant that the movement was all of a sudden huge. (Personal interview, August 2007)

Abdalla Adam Khatir, a renowned Darfuri journalist, used similar words to describe the beginning of the rebellion. He then added: "the SLA has a cause which makes them more resilient and compensates for their lack of military capabilities. The government and the Janjaweed don't have a cause" (personal interview, August 2008). Gibril Ibrahim, a JEM leader, agreed: "most importantly, we trusted in the power of our just cause" (personal interview, August 2007).

The SLA believed that once rebellion was ablaze in Darfur, rebel organizations from around the country would ally themselves to the rebellion (SLA/M 2003, 2). The International Crisis Group reported that in January 2004, the SLA reached an alliance 
with the Beja Congress, an ethnically-based armed group operating in Sudan's underdeveloped eastern states, and in February 2004, it joined the umbrella opposition National Democratic Alliance (NDA) $(2004,2)$. On 17 May 2004, Voice of America reported that SLA leader Abdelwahid Mohammad al-Nur, was quoted in the Arabic daily al-Hayat as threatening to "expand fighting into the central Sudanese area of Kordofan, the capital, Khartoum, and areas in the east" (Majtenyi 2004).

Information on the rebel leaders' efforts to maintain the moral upper hand and prevent civilian loss of life is consistent with the account of how they expected the rebellion to unfold. The rebels could not have compellingly called on Darfuris to fight with them if their tactics suggested they were not concerned with civilian casualties. Bashura Hassan el-Taher stated: "there was a conscious effort to maintain the moral highground. The SLA told people to leave to Chad before the fighting started. They also told the Fur to go to the towns and urban areas" (personal interview, August 2007). Melinda Young, who worked for Oxfam in Darfur in 2004, agreed on 9 August 2007: "the rebels were definitely the more ethical side of the conflict from the start. They fought largely within the laws of war. They maintained the moral high-ground; it was a deliberate strategy" (personal interview, August 2007).

Therefore, evidence detailed above indicates the SLA believed that, in order to extract their political demands from the government, they needed to build a force capable of threatening the capital. They assumed the justice of their cause would ensure the expansion of their movement. This implies that the SLA leaders did not perceive the rebellion as suicidal. It also suggests they were not relying on international humanitarian intervention to enable victory.

In fact, the rebels were not the only ones who believed in their military capabilities at 
the onset of the conflict. On 30 July 2007, Ablagasim Seif Eldeen, the Darfuri parliamentarian who headed the government delegation which negotiated with the rebels in the fall of 2002 and in February 2003, stated that not only did "the rebels believe they were strong enough to force the government to accept their demands for Darfur," he did too (personal interview, July 2007). This is a testament to how strong the rebels appeared at the onset of the conflict. Ablagasim Seif Eldeen, like most elite Darfuri men of his generation, was not supportive of the rebellion at its onset. These elders believed the rebels were poorly prepared, inexperienced and unwise to launch a rebellion against the government of Sudan. They believed the rebels' strategic vision was naïve, and the rebellion would do more harm than good. Such an endorsement of the rebels' strength at the onset of the conflict is therefore significant.

\subsection{Not a suicidal rebellion: The SLA believed their opponent was the military}

Empirical evidence presented below underlines that the SLA rebel leaders - and their skeptics - believed the movement would gain enough strength to march to Khartoum victoriously because they expected to face-off primarily against the Sudanese army. The rebels did not expect the Janjaweed and other militias to be their primary opponent. Dr. Mudawi Ibrahim Adam, who was in contact with the SLA leadership at the beginning of the conflict, said so explicitly (personal interview, August 2007). The rebels believed, prior to the onset of the conflict, that their forces would become strong enough to threaten Khartoum and extract their political demands for four reasons: the Sudanese army was at its weakest in decades, the army was largely Darfuri and loyal to the cause of Darfur, SLA tactics were innovative and strong, and JEM had contacts within the military.

First, the parties to the north-south conflict had achieved a military stalemate when 
they signed the Machakos Protocol in mid-2002 (Kenny 2004). The Sudanese military was exhausted from twenty years of conflict. It is reasonable to assume the rebels in Darfur would have learned this, at the latest by December 2002 given their contact with the SPLA at that time, but most probably before. In addition, the military outposts in Darfur were poorly supplied and generally run-down (Bashura Hassan el-Taher, Respondents 9 and 21: personal interviews, July and August 2007). The SLA therefore believed the Sudanese military was weak and would be unable to stave off another military opponent.

A second factor that led the rebels to believe their forces would become stronger than Sudanese military was the fact that the majority of its rank and file was Darfuri (Hassan al-Turabi: personal interview, July 2007; Prunier 2005). The rebels expected their brothers to either join them, or, at the very least, refuse to fight them (SLA/M 2003, 4). Both proved true: Ibrahim Ahmed Ibrahim, the SLA spokesperson in London, stated: "the government's army is from Darfur: they had no incentive to fight the rebels, so they fled when the rebels attacked" (personal interview, July 2007). Tag el-Khazin, a CanadianSudanese expert on conflict in Sudan, agreed: "after [the attack] on el-Fashir aiport, Darfuri non-commissioned-officers switched sides and helped the rebellion" (personal interview, July 2007; see also Haggar 2007, 128).

Third, despite having little military equipment, the rebels believed their guerrilla tactics would be superior to the slow, unmotivated formal military. While their actual equipment was rather sparse, the SLA employed clever tactics: their mobility, attacks at sunrise and sunset which put the sun in their opponents' eyes, and well trained, devoted soldiers were cited as evidence (Abdalla Adam Khatir: personal interview, August 2007; Prunier 2005, 100). Bashura Hassan el-Taher, an SLA mid-level leader who claimed to 
have regular contact with the International Republican Institute in 2007, stated that the Pentagon was so impressed it was studying the SLA's tactics in view of designing better counter-insurgency tactics for the US military (personal interview, August 2007).

Finally, the rebels believed they could develop the abilities to threaten Khartoum because, as Gibil Ibrahim shared in conversation in London, JEM had support within the Sudanese military (personal interview, August 2007). They expected these forces to undermine the military's response to the rebel attacks. "Unfortunately," he added, "the government found out and resisted these efforts." This account is corroborated by the events surrounding the 10 May 2008 JEM attack on Khartoum, which some believe failed in part because support for the rebels within the military did not/was unable to engage in combat (de Waal 2008).

"At the beginning, the rebels were too strong for the military," affirmed Respondent 9, who was in Darfur at the onset of the conflict but was not involved in the rebellion (personal interview, July 2007). Indeed, there is a consensus among Darfur scholars that the initial rebel attacks on the government were a success. Burr and Collins state that from March 2003 on, "fighting raged throughout West Darfur, and the victories of the SLA dramatically revealed the inadequacy and incompetence of the Sudan army" (2007, 291). This is best demonstrated by the fact that the government perceived the Darfuri rebels as a threat. I interviewed Hamid Mohamed Ali Taorain, a member of the Beni Halba tribe ${ }^{51}$ and a Minister in Bashir's government from 1996 to 2000, for two and a half hours (personal interview, August 2007). He stated that the government had been tracking the rebels since their first attack on the town of Golo in June 2002. The government initially viewed the rebellion as a nuisance and tried to avert war by bribing

\footnotetext{
${ }^{51}$ An ethnic Arab Darfuri tribe.
} 
the rebel leaders, and infiltrating the rebel movements. It was also nominally open to the calls and efforts of Ibrahim Suleiman, the Governor of West Darfur, to negotiate a political settlement. ${ }^{52}$ But after the stunning rebel attack on el-Fashir airport on 25 April 2003, the government decision-makers realized they had a problem on their hands. Fullscale retaliation was believed to be the government's only option. Suleiman was dismissed from his post and the Janjaweed and the Air Force were tasked with the counter-insurgency. Both Mudawi Ibrahim Adam and Abdalla Adam Khatir recounted the same story as Taorain (personal interviews, July and August 2007; Prunier 2005, 97).

In sum, the SLA appears to have expected to be able to threaten Khartoum because they anticipated their primary military opponent would be the Sudanese military. For the reasons enumerated above, they believed the military would not be a veritable challenge and saw themselves marching to Khartoum.

\subsection{Not a suicidal rebellion: Efforts to ally with the "Arab tribes"}

After the rebels defeated the Sudanese army in a number of impressive battles in early 2003, they did not get a free run to Khartoum. The Sudanese government primarily employed Janjaweed militias to fight the insurgency, but they also benefited from alliances with pastoralist tribes. It is important to distinguish between the Janjaweed militias and the Arab or pastoralist tribal militias in Darfur. "Janjaweed" is a loose term, which refers to armed militias which "had existed since the late 1980s in an indeterminate zone half-way between bandits and government thugs" (Prunier 2005, 97). These semi-

\footnotetext{
${ }^{52}$ I spoke briefly on the phone with Suleiman but was unable to meet due to conflicting schedules. Evidence suggests the government did not seriously consider making concessions to the Darfuri rebels at that time. At the Darfuri Leadership Conference in February 2003, presidential advisor Nafi al-Nafie (who was more powerful than Suleiman) accused the rebels of fomenting conflict in the hopes of being granted a negotiation process similar to the north-south process, and scoffed at the idea (Mohamed Baraka: personal interview, August 2007).
} 
autonomous armed bands were increasingly integrated into the formal military structure in Darfur as of 1999 (Haggar 2007, 114), and delegated the most egregious tasks (Petersen and Tullin 2005). While many Janjaweed fighters are ethnically Arab, and these groups do have formal agreements with some Arab/pastoralist tribal leaders, they are not synonymous with the Arab/pastoralist tribal defence militias. ${ }^{53}$ The latter, like all other tribal militias in Darfur, are armed groups that respond (mostly) to their tribal leadership. These tribes are numerous and well armed and can be a veritable force in Darfur (Tag elKhazin: personal interview, August 2007). "If I were a Darfuri rebel, I would have insisted on reconciliation with the Arabs, achieving political reconciliation. I would only have started operations against the government with the Arabs on board," said Edward Leno, a senior SPLA officer (personal interview, August 2007). The rebels' decision to instigate conflict without the support of the pastoralist tribes does indeed seem risky.

The government of Sudan had the support of the Janjaweed. They had also been courting the Arab tribes since the first rebel attacks during the summer and fall of 2002 (Mohamed Baraka: personal interview, August 2007; Flint and de Waal 2005, 80). Many individuals I spoke with recognized that, while they expected the government to respond to the rebellion with the military, they did anticipate some Arab/pastoralist tribal militias would fight along side the military. Bashura Hassan el-Taher, who was involved in SLA planning in the lead up to, and fighting at the onset of the conflict, said: "yes, we knew the government would use some proxy forces against us, but the level of violence, especially against civilians, was not clear ahead of time" (personal interview, August 2007). Given its nature, an alliance of the rebels with the Janjaweed was almost certainly

\footnotetext{
${ }^{53}$ Although the government's alliances with these actors over the past decade have increasingly blurred the distinctions between the military, the Janjaweed and the tribal militias.
} 
out of the question, but one with the Arab pastoralist tribal defence forces was not. A military alliance would have denied the government this weaponry and increased the rebels' strength. It would also have increased the credibility of the rebels' claim to fighting on behalf of all Darfuris. On 8 August 2007, Dr. Mudawi Ibrahim Adam, who was in touch with the SLA leadership in the lead up to the conflict, summed up the SLA leaders' considerations:

The SLA were conscious that the government would manipulate one tribe against another. They had fought the southerners for Khartoum for long enough. They did not want to fight their brothers again. Some in the SLA tried to reach out to the Arab tribes. (Personal interview, August 2007)

Hafiz Mohammed, a Darfuri academic, related how Abdalla Abakir, the SLA's head of military operations at the onset of the conflict, led an effort to build a military alliance with some of these tribes (personal interview, August 2007; Flint and de Waal 2005, Flint 2007; and Tanner and Tubania, 2007). While several Arab individuals joined the rebel movement, the SLA instigated the rebellion without a military alliance with these tribes or even their moral support for the rebellion. Evidence from my interviews suggests the SLA's failure to secure the support of the Arab tribes had as much to do with the Arab tribes being unable to perceive gains from an alliance with the SLA as it did with longstanding animosity between the Arabs and the Fur, Zaghawa and Masalit tribes from which the SLA drew its forces (Hamid Mohamed Toarain, Mudawi Ibrahim Adam: personal interviews, August 2007; Peter Schumann: personal interview, April 2008).

Had the rebels intended to launch a suicidal rebellion, they would not have worked to create an alliance with the pastoralist tribes. Yet given that they intended to build the capabilities to threaten the government, their decision to attack without the support of these tribes was indeed risky. The government did strike an alliance with some pastoralist 
tribes at the beginning of the conflict, but the alliance was short-lived and most of these tribes have largely remained outside of the conflict (Tag Elkhazin, Hamid Mohamed Toarain: personal interviews, July and August 2007). The SLA leadership would have known that a military alliance with the Arab/pastoralist tribes was unlikely and, perhaps, not worth delaying the rebellion given the preponderance of shifting alliances in Darfur. It is also important to add that the rebels did not have the full support of the Fur, Zaghawa or Masalit tribal leadership either (Flint and de Waal 2005, 80).

\subsection{Not a suicidal rebellion: The SLA did not anticipate genocidal violence}

As detailed above, Dr. Hassan al-Turabi and the members of the SPLA (which fought Turabi's forces for over twenty years) stated that the government's response to the rebel attacks was predictable: the Darfuri rebels should have known civilians would be the primary target (Hassan al-Turabi, Edward Leno, Respondents 10 and 11: personal interviews, July and August 2007). Yet they did not. Although the rebel leaders expected some retaliation against civilians, all Darfuri respondents with whom I addressed the question - individuals both near and far from the rebel leadership - and all international respondents argued that that the scale of horrors was not predictable. This undermines the hypothesis that the rebels attacked the government in order to intentionally provoke a humanitarian catastrophe.

Darfuris perceived themselves to be an integral part of Sudan. They are Muslim, like the people of Khartoum. For years the government called on them as "brothers" to fight jihad against their "common enemies", the south Sudanese "infidels", and the Darfuris had responded to the call in droves. Respondent 32, a Darfuri activist in London, described how members of the ruling party came to his village when he was a boy and 
rallied the villagers to fight the south Sudanese (personal interview, August 2007). As mentioned above, the Sudanese army rank and file was mostly Darfuri: these men and women fought for years on behalf of the government. Despite the fact that government investment in Darfur was minimal, Khartoum's manipulation of local politics was rampant, and the government provided no security for the citizens of Darfur, those I spoke with argued Darfuris never anticipated the government would turn on the people of Darfur.

What appears to explain the discrepancy between Turabi and the SPLA's anticipation of violence on the one hand, and the SLA's blindness on the other, is the fact that information on conflict does not flow from one region to the other in Sudan. Rather surprisingly, the rebel leadership - and Darfuris in general - appear to have been unaware of the tactics and magnitude of the violence used by the government and its proxies against civilians in south Sudan. Gibril Ibrahim, a senior JEM leader and brother of Khalil Ibrahim (founder and leader of JEM), admitted that he felt "very guilty" about the violence committed against the people of Darfur as a result of the rebellion (personal interview, August 2007). "The least calculated result of the conflict," he said, "is what happened to the people. Darfuris, including the JEM leadership had little knowledge of violence in the south. It was a miscalculation on our part, we just didn't know." Evidence supporting his claim came to light during a meeting I attended on 12 July 2007 at a Darfuri organization in Khartoum. The topic of discussion was post-conflict reparations for Darfuris. In attendance were five Darfuri academics, human rights activists and practitioners. While discussing the conflict, they spoke of the unprecedented human devastation in Darfur; how such killings, displacement and sexual violence had never been seen before in Sudan. Sadly, this is factually incorrect. The speed with which the 
government proxies perpetrated the violence in Darfur was unprecedented, but the government employed similar tactics during its twenty year campaign against the people of south Sudan, with more devastating human consequences. A conversation with Medina Hussein Dosa, who holds a PhD in Psychology from the University of Khartoum and runs a gender and development center in Nyala, South Darfur, provided some additional perspective. She spoke of their being very little knowledge in Khartoum of the "current catastrophic conditions" in Darfur (personal interview, July 2007). This lack of circulation of information may be explained by government policies: "at one point, according to a [Sudanese] political newspaper editor, $[\ldots]$ media in Sudan were ordered by security forces not to publish the word 'Darfur' or anything in relation to that region whatsoever" (Kamal el-Din 2007, 92). Yet given the fact that so many Darfuris were in the military and fought in the south, and that JEM's leaders were former members of the government, this hypothesis remains puzzling and merits further investigation.

In addition, the integrity of the rebel leaders was raised time and again during my inperson interviews. All of the participants I interviewed with whom I addressed the question argued that the SLA leaders did not intentionally provoke a humanitarian catastrophe. Florian Baalcke, a UN Field Security Coordination Officer based in el-Fashir stated in response to Kuperman's hypothesis that he believed "the commanders did not want to see their people suffer, nor was it in their interest to be responsible for civilian suffering" (personal interview, August 2007). Both Elizabeth Hodgkin and Benedict Goderia from Amnesty International, who spent considerable time with the rebel leaders in Darfur, were dead-set against the hypothesis tested in this research (personal interview, August 2007). Both emphatically insisted that the rebels were good, upstanding people, albeit perhaps somewhat naïve. When confronted with the question of whether the rebels 
intentionally provoked a humanitarian catastrophe, Edward Leno, senior SPLA officer, paused to reflect. He conceded that perhaps the SLA was, in part, responsible for the human suffering because he felt the violence was predictable; but he adamantly stated that it was never the SLA's intention to provoke the humanitarian crisis (personal interview, August 2007).

It is important to acknowledge that testimony suggesting the SLA leaders anticipated genocidal retaliation would be difficult to uncover. The conflict is still ongoing: all available evidence was, therefore, collected while the SLA leaders and key participants had a stake in the conflict. The implications of having anticipated violence and knowingly sacrificed civilians would be devastating for the integrity and authority of these individuals, both vis-à-vis survivors in Darfur and the international community. Nevertheless, albeit limited, the evidence presented convincingly suggests the SLA did not anticipate the extent of the violence against civilians and, therefore, did not intentionally provoke a humanitarian catastrophe. This implies that they did not foresee ahead of instigating the conflict that they required the force capabilities to protect civilians. Their inability to do so once the violence was unleashed was thus not an indication of a suicidal strategy. Rather, it highlights the risks involved in choosing armed rebellion as a means to a political end.

\subsection{Not a suicidal rebellion: The SLA's communication strategy}

Several participants testified that the SLA leaders believed the greatest threat to victory was government misinformation, greater even than the military. The information presented so far suggests the rebels' strategic vision rested on convincing Darfuris - and, ultimately, all marginalized Sudanese - that the SLA was fighting for a just cause from 
which all would benefit and, therefore, which all should join. As detailed in Chapter 2, Daud Bolad launched an unsuccessful rebellion in Darfur in 1991 for reasons similar to those enumerated by the SLA. With the direct help of the SPLA, he launched attacks against the government in Darfur in late 1991 in the hopes of spurring a rebellion. His lack of proper equipment did not help, yet he failed primarily because he had no means of communicating to the Darfuri people who he was and what his objectives were. The government capitalized on this and mobilized the population against the uprising (Respondents 9, 11, 16, 17, 21, Edward Leno and Hafiz Mohammed: personal interviews, July and August 2007; Prunier 2005, 73-74; Flint 2007, 142-143).

Respondent 21, a Fur SLA fighter with whom I spoke on 8 and 9 August 2007, recounted how he quit the Sudanese army in 1991 to join Bolad's rebellion (personal interview, August 2007). He had spent the years since then fighting the government in various regions of Sudan, including the east, south and Darfur. He affirmed that the SLA leaders had reflected on Bolad's failure and were aware of the importance of informing the Darfuri population of their intentions. He described how they devoted energy and resources to this objective.

Before the major victories in Golo (February 2003) and the el-Fashir airport (April 2003), the SLA had very little means of communicating its message (Bashura Hassan elTaher: personal interview, August 2007). Therefore, "people didn't know the intentions of the rebels. The government capitalized on this and used the media to accuse the rebels of being robbers," said Respondent 9, who was in Darfur at the time but not part of the rebellion (personal interview, August 2007). Indeed, the government's first reaction was to deny the existence of a political rebellion: Muhammad Ahmad Dirdeiry, the spokesman at the Sudanese embassy in Nairobi, told the UN Integrated Regional 
Information Networks (IRIN) on 27 February 2003, one day after the major rebel attack on the town of Golo, that the Darfuri rebels were a "gang of bandits" who had been terrorizing residents of the region and who had "no political agenda" (IRIN 2003). To the international community, the government dismissed the conflict as "tribal and ethnic" (Azzain Mohamed 2007, 208; Prunier 2005, 100).

The rebels feared the government's public relations campaign would cost them the rebellion. They therefore capitalized on national media attention around their big victories to get the word out to fellow Darfuris. As alluded to above, the attack on the el-Fashir airport (25 April 2003) was reported in national media (radio, television and newspaper) and SLA leader Mini Minawi and JEM leader Khalil Ibrahim conveyed to the public details of the conflict and the rebels' demands at that time (Respondent 9: personal interview, August 2007). Also, as quoted earlier, Mudawi Ibrahim Adam underlined that it was only thanks to the attack on el-Fashir that the rebels really communicated their message to the Darfuri people (personal interview, July 2007). In fact, Respondent 34, a UN official who had worked in Darfur, suggested the SLA and JEM chose to attack elFashir airport in such a brazen and provocative way - destroying the fleet of airplanes and kidnapping a Sudanese army General - to garner media attention as a way of publicizing their cause to Darfuris. "The rebels were concerned about the planes and the damage they could do to their bases, but also looking for a bull's-eye. They knew they needed something to propel them, their cause. This was a great opportunity" (Respondent 34: personal interview, August 2008). As discussed briefly above, the rebels predicted accurately: the rebellion "exploded" once Darfuris understood the SLA's intentions.

Evidence also suggests that before and at the onset of the conflict, more SLA resources - primarily time and energy - were directed toward alliances with local and 
regional actors than with international actors. At the onset of the conflict, the SLA had offices in the Horn of Africa, had sought support of Chadian President Deby and the Eritrean government (Respondent 35: personal interview, August 2008; Jane's Intelligence Review 2008). They had also sought alliances with other rebel and political organizations in Sudan, as well as funding and support from the Darfuri diaspora (Abdalla Adam Khatir, Mudawi Ibrahim Adam, Bashura Hassan el-Taher: personal interviews, July and August 2007; Tanner and Tubania 2007, 20-22). Their efforts to communicate with the international community, detailed above, paled in comparison. Phil Cox, the London-based film director whom I interviewed on 12 August 2007, offered the SLA camera equipment in late 2003 to capture images of the conflict and relay these to the world. The SLA rebels received the camera and used it once, "but they were not on the ball with regard to getting images of the conflict and its human consequences out to the world" (Phil Cox: personal interview, August 2007). He offered two explanations for this: first, the SLA leaders believed they could march to Khartoum and achieve their political objectives on their own. Second, once they understood the potential benefits of media attention, which they did only after the humanitarian crisis was a full-blown catastrophe, "they simply did not understand what Western policy makers wanted and needed to hear."

During the same conversation, Cox recounted an anecdote that he felt characterized the SLA's relationship with the international community. After the conflict was set in motion, he secured a fifteen-minute meeting between SLA representatives and top officials from the British Foreign and Commonwealth Office. This was an ideal opportunity for the SLA to make their pitch to international individuals of consequence, all the more so if they were counting on international intervention to enable victory. Yet, according to him, they failed miserably: the Darfuri representatives started the meeting 
with: "in 1916, Darfur was an independent Sultanate..." and used their precious minutes to recount the long and tortuous $20^{\text {th }}$ century history of Darfur (Phil Cox: personal interview, August 2007). Cox continued: "in the media, they don't have a coherent vision, they contradict each other on air; they don't have a 15 second sound-bite. Unbelievably, after four years of conflict, they still have not perfected this." Both points - that the rebels made little effort to communicate to the world at the onset of the conflict, and the efforts they did eventually make were painfully misguided - were echoed in much gentler terms by Liz Hodgkin and Benedict Goderia (personal interview, August 2007).

These anecdotes must be understood in context: cultural factors such as communication style and the concept of time can help explain the rebel leaders' inability to master the "15 minute pitch" and the "15 second sound bite", feats which are admittedly challenging. They do suggest, however, that communicating with the international community was not the rebels' foremost priority at the onset of the conflict, whereas communicating their message to their fellow Darfuris was. While it is possible the rebels expected a catastrophe to garner international attention "on its own" (without a rebel communications plan), the qualitative data collected for this research indicates that the SLA leaders did not cunningly calculate ahead of launching the rebellion that a humanitarian catastrophe would advance their political objectives. In addition, they do not appear to have been relying on the international community artificially inflating their strength vis-à-vis the government in order to achieve victory. It must also be mentioned that Gibril Ibrahim, a senior JEM leader, stated clearly that JEM never asked for or expected international intervention in the conflict in Darfur (personal interview, August 2007).

Elsewhere, it is relevant to make sense of some outlying statements. In an interview 
in London on 10 July 2007, the SLA London-based spokesperson acknowledged: "the international community intervenes when there is a humanitarian catastrophe on the ground" (Ibrahim Ahmed Ibrahim: personal interview, July 2007). A little over a month later, a London-based Darfuri activist associated with the SLA also recognized:

While there are no strategic interests in Darfur [relevant to international actors], there is media interest, which is guaranteed by the massive violence against the people. At the beginning of the crisis, the media were not interested because there were not enough people dying. (Respondent 32: personal interview, August 2007)

These statements appear to suggest the SLA was aware of the link between humanitarian catastrophes, media coverage and international involvement in a conflict, and may have used this knowledge to advance their political objectives.

Yet, as detailed above, the timeline of the rebels' attention to the international community (little focus before and at the onset of the conflict), as well as testimony from Westerners who advised the SLA leaders on their communications strategy (Phil Cox, Elizabeth Hodgkin and Benedict Goderia: personal interviews, August 2007), suggest that this link only became clear to the rebels once the humanitarian crisis was in full-swing and international diplomatic and media attention was on them, ${ }^{54}$ which I will examine in more detail later in this chapter.

\subsection{Not a suicidal rebellion: The inexperience of the rebel leaders}

The inexperience of the SLA rebel leaders was a recurrent theme in the in-person interviews I conducted. "Darfuri rebels always had expectations that were unrealistic. They wanted to march to Khartoum: this was impossible! The SPLA was stronger, the international circumstances were better, and they did not manage to do so," said

\footnotetext{
${ }^{54}$ Diplomatic circles and advocacy NGOs became aware of, and to a certain extent, attentive to the situation in late 2003 and early 2004 (Prunier 2005, 124-129); widespread media attention occurred in the spring of 2004 (Hamilton and Hazlett 2007).
} 
Respondent 10, an SPLM political advisor (personal interview, August 2007). Twentythree of the thirty-five participants I interviewed spoke of the fact that the rebels were in over their heads when they instigated rebellion against the government in 2003 . They used words such as: "too young", "immature", "naïve" and "lacking experience" (personal interviews). The respondents who did not speak of the youth and immaturity of the SLA rebel leadership were either affiliated with the SLA or respondents with whom I was unable to speak about the SLA leadership due to political sensitivities in Khartoum.

Indeed the SLA rebel leaders were in their early thirties, had little to no leadership experience and gave the general impression that they did not know what they were doing. This became apparent in two ways: the leaders demonstrated a lack of organizational capacities as well as no clear political direction. With regard to the latter, the SLA leaders were described as: "disorganized" and "unprepared"; they "launched prematurely", "took up arms before becoming coherent", "did not know ahead of time what they were doing", "did not do enough ground-work", and "put not real effort into creating solid structure, a mature organization" (personal interviews, July and August 2007; Flint 2007, 160). As detailed above, a number of respondents described how the rebellion "exploded" after the attack on el-Fashir airport. While this was technically a strategic success - it was the rebels' objective - it meant any coherence the fragile organization once had, they lost. With individuals across Darfur taking up arms and claiming they were SLA fighters, the movement became huge but lacked a clear chain of command.

Second, the participants argued the SLA leaders "never knew what they wanted", "had unrealistic objectives", and "had no political vision" (personal interviews, July and August 2007; August 2008). The SLA did not take the time to clarify their specific objectives before instigating the rebellion, were likely manipulated by the SPLA and did 
not benefit from the experience of their elders. Their eloquently drafted political manifesto (SLA/M 2003) is, in fact, misleading. It speaks of the injustices in Darfur - and Sudan - but does not spell out in detail the SLA's demands. It is, in fact, a more accurate reflection of the SPLA's vision than what the SLA was fighting for. Several participants suggested the SPLA's support for the SLA was motivated by self-interest: an insurrection would illustrate the arguments Dr. Garang was making at the Naivasha peace talks, notably about the marginalization of peripheral regions in Sudan, and thus benefit his negotiating position. Bashura Hassan el-Taher stated: "more conflict in Darfur is better for Garang's position at Naivasha" (personal interview, August 2007; Prunier 2005, 106; Tanner and Tubiana 2007). Gibril Ibrahim, a senior JEM leader, also recounted:

Dr. Garang initially came to Abdelwahid [leader of the SLA] and to JEM, and asked them to join the SPLA. Both organizations refused as they feared they would have no power within the SPLA/M and their political demands for Darfur would me marginalized within the movement. Even if the Darfuri groups didn't join, the SPLA/M definitely gained from the conflict in Darfur. (Personal interview, August 2007)

In addition, the Darfuri rebels did not benefit from the wealth of knowledge and experience of their elders. Bashura Hassan el-Taher, the mid-level SLA leader who was party to the build up of the rebel movement, stated that the rebels feared the Darfuri elites would "sell them out", but admitted they later realized that this was a mistake: the rebels would have benefitted from working with these experienced individuals (personal interview, August 2007).

All respondents with whom I addressed the question denied that the rebels were "fraudulent" - that they knowingly instigated a humanitarian catastrophe; most believe that they were simply incompetent. Rather candidly, Respondent 34 , a UN official who worked in contact with the rebels in Darfur, stated the SLA "had no geniuses on their team" (personal interview, August 2008); Edward Leno echoed this sentiment (personal 
interview, August 2007). The Darfuri rebels were facing enormous challenges: the salient ethnic cleavages in Darfur meant the government could easily manipulate "Arabs" against the "Zurga" ("Africans") (Respondent 9: personal interview, July 2007). Longstanding mistrust between the tribes in the rebel movement - notably the Fur and the Zaghawa meant creating internal cleavages was also effortless (Bashura Hassan el-Taher: personal interview, August 2007). The rebel movement had little military equipment and existence was hand-to-mouth in the camps in the Jabel Marra. Furthermore, the SLA's foe - the government of Sudan - was a formidable enemy: it had fought for nearly twenty years against a well equipped and seasoned military opponent with exceptional leadership (Edward Leno: personal interview, August 2007). The government had learned how to survive by manipulating and fighting (Phil Cox, Elizabeth Hodgkin and Benedict Goderia: personal interviews, August 2007). Given this context, a "competent" Darfuri rebel leader may have been one who chose not to rebel against the government of Sudan.

\subsection{Evidence undermining the hypothesis: Conclusion}

When the narrative outlined above is taken into consideration, the hypothesis $\mathrm{I}$ am testing, as well as Kuperman's theory in general, appear less helpful at explaining the occurrence and timing of the rebellion in Darfur. Evidence suggests the Sudan Liberation Army/Movement leaders recognized that to extract concessions from the government, they needed to be able to threaten Khartoum militarily. They believed they could build such a force. The leaders sought alliances with national and regional actors more than they did with international actors. They envisioned the rebellion spreading throughout Darfur once citizens became aware of its objectives. The SLA leaders therefore focused 
their communication efforts at the beginning of the conflict on informing Darfuris and countering the government's campaign to label them as "robbers".

In addition, evidence suggests the SLA leaders believed their forces would be enough to achieve victory because they anticipated their opponent would be the military, which was weak. The SLA leaders made efforts to build an alliance with the Arab tribes in order to benefit from their military capabilities and moral support, but this alliance failed. Evidence suggests the rebel leaders did not anticipate the government would retaliate with genocidal violence. Most participants describe the SLA leaders as dangerously naïve and incompetent, yet all maintain the rebellion was not intentionally suicidal and the rebel leaders did not knowingly provoke violence against civilians in Darfur.

\section{Analysis}

The evidence presented in this research paints two pictures which initially appear to conflict. The rebels "made clear statements to the international community before launching the rebellion." (Peter Schumann: personal interview, April 2008). At the same time, they intentionally instigated full-scale rebellion against the government in 2003 because they believed they could achieve military victory on their own.

After a closer examination, these two story-lines present a nuanced and coherent understanding of this complex situation. As the SLA rebels were instigating violence against the government, they were aware of the international community's role in bringing the parties to the north-south conflict to the negotiating table and hoped to benefit from this spirit of intervention. They believed the international community would send humanitarian assistance to alleviate suffering and requested they sponsor a negotiations framework. 
Despite seeking some international help, the rebels SLA leaders believed they could build the military strength necessary to credibly threaten the government on their own, by virtue of the justice of their cause. While others would have foreseen the government's retaliation against civilians, evidence suggests the SLA leaders did not and therefore instigated rebellion without the ability to protect civilians from violence. The rebels appear to have concentrated their energies before and at the onset of the conflict on gaining the support of local, national and regional civilians and actors, which is consistent with their strategic vision. This suggests that the rebels recognized that, while it would be helpful, international pressure would not guarantee them a seat at the negotiating table: only military strength would allow them to extract their political demands from the government. The following section examines the implications for the hypothesis and tentatively suggests alternative explanations of the occurrence and timing of the rebellion in Darfur.

\subsection{Assessing the hypothesis}

As described in Chapter 4, Kuperman describes two ways subjugated rebel groups could respond to the prospect of international humanitarian intervention (moral hazard): with fraudulent or irresponsible behaviour. "Fraudulent behaviour" is described by Kuperman in the following way:

In some cases, moral hazard promotes outright fraud: for example, rebels will attack state officials deliberately intending to provoke retaliation against their own group's civilians, to attract international intervention that they deem necessary to attain their political goals. In practice, intervention does sometimes help rebels attain their goals, but usually it is too late or inadequate to avert retaliation against civilians. $(2008 \mathrm{a}, 51)$

The "irresponsible" hypothesis is described as:

In other cases, moral hazard promotes irresponsibility: for example, a group's leaders will acquire arms and secede from the state even though they know this may trigger state 
retaliation that they cannot defend against, because they expect the international community either to deter such retaliation or intervene on their behalf in the event of violence (Kuperman 2008a, 51)

Both of Kuperman's scenarios explicitly link international support for a rebel movement to the occurrence of disproportionate state retaliation.

This research tested the "fraudulent" hypothesis. It is the rebels" intentions - not the outcome of the rebellion - that are relevant to the hypothesis. The evidence presented in this research suggests that the SLA rebels did not believe the rebellion was suicidal. They believed they could build the military capabilities to coerce the government into granting their political demands. They, therefore, believed the risks involved in launching a rebellion were low, and did not intentionally choose a path that was harmful to themselves or their civilian support base. The fact that the rebellion was not suicidal implies that the SLA leaders did not engage in fraudulent behavior: they did not intentionally provoke a humanitarian crisis. This hypothesis therefore does not describe the strategic vision of the SLA leaders at the onset of the conflict.

In the second scenario, the prospect of humanitarian intervention allegedly entices rebel groups to take more risk than they would otherwise because they believe they are "insured" by the international community. In their Political Declaration, the SLA requested the international community send immediate humanitarian assistance to Darfur to alleviate ongoing suffering. The rebels also appear to have expected the international community to sponsor separate peace talks and pressure the government to participate. These represent (perceived) insurance. Yet because all available information indicates the rebel leaders did not anticipate genocidal violence to ensue, the rebels are unlikely to have believed they needed "insurance", and therefore unlikely to have rebelled at this time because the international community offered a unique protection against state 
violence. While the expectation of international support for their struggle appears to have been a contributing factor to the timing of the rebellion, evidence presented here does not suggest it was a determining factor. I will examine this in more detail later.

The available information therefore tentatively suggests that, at the onset of the conflict in Darfur, the causal connection between the international norm of humanitarian intervention and rebellion was the reverse: the rebels unintentionally caused a humanitarian catastrophe, which eventually triggered international diplomatic and media attention, which mitigated the violence against civilians in Darfur (Petersen and Tullin $2006),{ }^{55}$ which enticed the rebels to seek international intervention to protect their people and enable rebel victory (Edward Leno: personal interview, August 2007). This sequence of events endorses the conventional wisdom on the conflict in Darfur and compellingly rejects Kuperman's hypothesis.

These findings are fragile for several reasons. The limited quantity of information gathered and the fact that the conflict was still ongoing undermine the validity of my findings. In addition, George and Bennett highlight that in-depth case-studies are helpful at identifying contributing factors to decision-making processes, but poor at quantifying the influence of these factors on the decision in question $(2005,26)$. The fact that the central theses of Kuperman's hypothesis do not describe the conflict in Darfur does not, in itself, impact the validity of Kuperman's theoretical framework. Kuperman argues that rational deterrence theory predicts that subjugated groups choose to rebel against the state in conditions in which genocidal violence is likely and success unlikely for five reasons

\footnotetext{
${ }^{55}$ Petersen and Tullin (2006) report two sudden drops in violent mortality caused by Government and/or Janjaweed attacks on villages which correlate with the an uptake in UN news service coverage of the crisis in September 2003 (IRIN), as well as with an uptake in international media coverage end March/April 2004 (LexisNexis). See Footnote 21 for methodology.
} 
(Table 1):

1. Do not perceive credible threat by state to retaliate

2. Expect victimization anyway, so nothing to lose

3. Expect victory at tolerable cost w/o intervention

4. Expect international intervention to enable victory at tolerable cost

5. Do not behave as unitary rational actors

Only when conditions $1,2,3$, and 5 do not explain the occurrence of rebellion does Kuperman argue that subjugated groups rebel because they "expect intervention to enable victory at a tolerable cost." In this case, the SLA leaders "did not perceive as credible the state's threat to retaliate", and they "expected victory at tolerable cost without international intervention." The conflict in Darfur therefore does not appear to fall within the scope of Kuperman's framework of moral hazard, which, therefore, does not purport to explain the puzzle.

\subsection{Alternative hypotheses}

The objective of this research is to improve the historical explanation of the onset of the conflict in Darfur. Kuperman's theory does not appear to compellingly explain why the rebels attacked the government when they did. Nevertheless, George and Bennett highlight that "process-tracing can perform a heuristic function $[\ldots]$, generating new variables or hypotheses on the basis of sequences of events observed inductively in case studies" $(2005,7)$. The following ideas are presented as tentative hypotheses which merit future research.

\subsubsection{The SLA's strategic vision: The foco theory of rebellion}

If the conflict was not suicidal, then the puzzle disappears. The answer to the question "why did the SLA rebel leaders choose to rebel in conditions that were grossly 
unfavourable to their success, at great risk to themselves and their civilian support base?" is: because they did not believe the conditions were unfavorable. Yet the situation remains puzzling as the basic facts have not changed: the SLA leaders launched a rebellion before they had a cohesive fighting force or all but the most basic equipment, an effective communications strategy or widespread support amongst the traditional political leadership in Darfur. Despite having addressed why the rebels did not consider some of these factors a hindrance to success, the overall picture of the initial conditions does not appear conducive to victory. This of course begs the question: why did they believe they could win in these conditions?

The foco theory of rebellion appears to encapsulate why SLA leaders believed they could win despite the sub-optimal conditions. In 1960, shortly after the Cuban revolution led by Fidel Castro, Ernesto "Che" Guevara, a prominent guerrilla fighter, published an extended essay entitled "Guerrilla Warfare". It offers both philosophical and practical guidelines to would-be rebels about how to succeed militarily with significant support from the masses (Johnson 2006, 26; Weinstein 2007, 29). In brief, the "foco" refers to a small guerrilla band usually located in the mountains: the insurrectionary force. The "foco theory" refers to the guerrilla warfare literature authored by Che Guevara, Regis Debray, and Fidel Castro, which gives a central role to rural armed struggle and emphases subjective conditions (Childs 1995, footnote 4). Guevara's (1960) three central theses are:

1.Popular forces can win a war against the army;

2. It is not necessary to wait until all the conditions for making revolution exist; the insurrection can create them;

3. The countryside is the basic area for armed fighting.

While the second and third points are what led to a distinctive revolutionary theory (the foco theory), all three appear to characterize the intentions and actions of the SLA leaders 
in Darfur. The first point is straightforward: a guerrilla army can defeat a regular army. In the second, Guevara abandons what he believed was a defeatist and overly patient outlook in favor of immediate action initiated by an elite few (Johnson 2006, 27). He breaks with conventional Marxist theory and argues that history can be sped-up: conditions for success can be created when the "elite few" are able to awaken the peasantry to their oppression and entice them to join the rebellion. One of the reasons Guevara contends victory is possible is that a limited number of provocative attacks are likely to "draw an oppressive state to use more extreme levels of opposition, thus radicalizing all levels of government opposition" (Johnson 2006, 27). No need, therefore, to have a force capable of achieving military victory from the start; initiating rebellion will create the conditions for such a force to be built.

The rebels' strategic vision and behaviour are largely consistent with the foco theory. The SLA leaders were an "elite few" who appear to have precipitated an armed struggle in conditions that were not conducive to success because they believed that knowledge of such a rebellion would awaken the masses to their marginalized conditions and swell the ranks of the movement. Their reliance on a few provocative victories - notably the attack on the el-Fashir airport (April 2003) - echoes the foco idea that military victories are the most effective means of garnering popular support for the rebel cause (Desai and Eckstein 1990, 464). In addition, Darfuri rebel ranks mushroomed as a result of state retaliation (Haggar 2007, 128). ${ }^{56}$ The theory, therefore, substantiates the rebels' strategic vision, which initially appeared puzzling. In a short essay on JEM's attack on Omdurman in May 2008, de Waal compellingly argues, in fact, that Khalil Ibrahim (leader of JEM), is guided

\footnotetext{
${ }^{56}$ Evidence I gathered through in-person interviews suggests the rebels expected some retaliation against civilians, but did not expect genocidal violence. The discrepancy between the theory, the rebels' intention and the outcome (state violence) merits further investigation.
} 
by a foco-ist strategy (de Waal 2008).

In addition, fragile evidence suggests the SLA leaders may have come in direct contact with the foco theory of rebellion. Childs writes: "Che Guevara's writings on guerrilla warfare found a receptive audience not only in Latin America, but throughout the world" $(1995,598)$. Weinstein references the theory's spread to the Horn of Africa (2007, 31-32). Haggar writes of Muammar al-Gaddafi: “the Libyan leader's philosophy of 'revolutionary necessity' was built upon the experience of Latin America's rebels in Bolivia, Cuba, Chile and other countries [...]. [He] also used the doctrine of the foco-ist revolutionary Che Guevara" (Haggar 2007, 122). Links between the Darfur insurrection and the Libyan leader are well established (Burr and Collins 2007). Finally, Peter Schumann, a former senior UN official, asserted that both Dr. John Garang (leader of the SPLA) and Abdelwahid Mohammed al-Nur (leader of the SLA) had read and were influenced by the revolutionary theorists Mao Zedong, Fidel Castro and Che Guevara, all of whom "romanticize rebellion," he added (personal interview, April 2008).

The SLA launched the rebellion in conditions that were not conducive to "achieving victory on their own", ${ }^{57}$ yet they appear to have truly believed the power of their cause would enable them to build a force strong enough to threaten the government. Why did they believe they could win? Their lack of knowledge of the government's actions in past conflicts, political and organizational inexperience, and a certain amount of naïveté provides some answers. In addition to these factors, SLA rebels' strategic vision, which appears to be grounded in the revolutionary tradition of Latin America, is informative.

57 The conflict is still ongoing, implying that the rebellion's success cannot yet be fully assessed. Nevertheless, the rebels' strategic vision at the onset of the conflict (best summarized by the foco theory of rebellion) did not succeed: the rebels were unable to credibly threaten the government their own. Given the heavy international involvement, future success would not change that fact. 
The rebels may have been exposed to the theory, or they may have been acting on their own intuition, as Guevara and others did before he drafted this seminal piece. The notion that conditions for success can be created by violence tentatively explains why the Darfuri rebels believed victory was possible despite the sub-optimal conditions that existed in 2003. The scope of this research does not allow me to delve into why the rebels' strategic vision did not pan out, whether because the foco theory is invalid, or the theory's scope conditions were not met, or the Darfuri rebels did not operationalize it correctly. I am simply proposing it as a preliminary tool to square the circle, to understand why the rebels believed they could win when the conditions do not appear to have been conducive to success.

\subsubsection{Timing of the rebellion: The moral hazard of negotiated settlements}

While the evidence on hand suggests the SLA leaders did not expect international intervention to "enable victory at tolerable cost", some evidence indicates the timing of the rebellion was linked to the Naivasha negotiations by a different, though similar, mechanism. The negotiations themselves appear to have enticed the Darfuri rebels to initiate conflict when they did. Many international experts have echoed this idea, including Power (2004), the International Crisis Group $(2004,19)$, Prunier $(2005,108$, 121), Straus (2005), Belloni $(2006,335-336)$, Tanner and Tubiana $(2007,16)$ and Johnston $(2007,364)$. In addition, my informal discussions with Western diplomats and international public servants in Khartoum (July-August 2007) revealed comparable arguments. Of these authors, only Belloni (2006) and Johnston (2007) have investigated this claim in some detail based on a review of the literature. 
Johnston (2007) highlights that negotiated settlements can create a perverse incentive for rebel groups that are left out, enticing them to rebel in conditions they would not otherwise. First, the occurrence of power-sharing negotiations demonstrates that conflict is an effective means to power. Second, they create the opportunity for spoilers and, thereby, lower the bar for rational entry into conflict: rebel movements no longer need to achieve military victory, they must simply disrupt the peace. Third, active international support for the negotiated resolution of conflict leads excluded rebel groups to believe the international community will act to avoid war and pressure the parties to the ongoing negotiations to share their winnings (thereby artificially inflating the strength of the spoiler). These factors can entice rebel groups to initiate conflict in conditions they would not otherwise. As outlined in Chapter 4, Kuperman defines international actions which encourage/entice negotiated settlement as "humanitarian intervention". This hypothesis is distinct form Kuperman's argument of moral hazard of humanitarian intervention insofar as it does not link the anticipation of international support for a rebel movement to the occurrence of disproportionate state retaliation. It also recognizes multiple causal paths that may lead rebels to initiate violence against the state while power-sharing negotiations are ongoing.

Some evidence supports the three criteria as they apply to Darfur. First, the Naivasha negotiations strengthened the notion that conflict was an effective a means to political ends in Sudan: "the government could not beat the SPLA militarily so they negotiated a political settlement. Conflict is the only way to get anything in Sudan," said the SLA spokesperson in London (Ibrahim Ahmed Ibrahim: personal interview, July 2007). Sudan's political elite - Hassan al-Turabi (personal interview, August 2007) and Edward Leno (personal interview, August 2007) - echoed this belief, as did many Darfuris. In 
addition, Dr. Garang, the leader of the SPLA, advised the SLA rebels before they initiated violence that in order to gain concessions from the government, they first had to fight (Edward Leno: personal interview, August 2007; Flint and de Waal 2005, 82). While this was not a new concept in Sudan, this evidence suggests the north-south negotiations strengthened expectations of this pay-off structure.

Second, the hypothesis linking conflict to the occurrence of negotiated settlements predicts the Darfuri rebels believed the military capabilities necessary to extract their demands from the government were less than they would have otherwise been because the SLA rebels only had to disrupt the peace (be spoilers), not topple the government. The existing information is ambiguous. Given that SLA leaders were aware of the negotiations when they launched the conflict, it is reasonable to assume they would have recognized this dynamic. On 23 October 2003, Agence France Press (Cairo) reported:

SLM [leader] Mini Arkoi Minawi told AFP by telephone from his base in the western region of Darfur. 'We want a comprehensive peace for all of Sudan - north, east, west and south,' Minawi said when asked about the Kenya talks. 'The government and the south do not represent all of Sudan. There are many neglected regions.' Pressed on what his movement's position would be if Khartoum and the SPLA pressed ahead with a separate settlement, he said: 'We will represent an obstacle to the achievement of such a peace.' (AFP 2003)

Minawi explicitly threatened to spoil the negotiations. However, the statement was made 6 months after the onset of the conflict and, thus, does not necessarily represent the SLA's intention at its onset. The empirical evidence presented in this research, including reference to the foco theory of rebellion, suggests that when the rebels launched the rebellion, they believed they could develop the strength to credibly threaten the government for other reasons than being "spoilers". Furthermore, it is relevant to recall, again, that Garang advised the SLA leaders to fight (in December/January 2002/2003). This indicates that he did not perceive a rebellion in Darfur to be a threat to his claims to Sudan's power and resources at the Naivasha negotiations. Therefore, the available 
evidence does not allow me to assess this criterion.

Third, the hypothesis predicts the rebels would have expected the international community to pressure the government (and the SPLA) to negotiate an agreement with the Darfuris, thus artificially inflating the SLA's strength (and decreasing the military capabilities necessary for success). The information presented does not support the claim that the rebels believed they could gain access to the Naivasha negotiating table. Before instigating conflict, the SLA rebels communicated to all parties involved in the negotiations their intention to rebel and their political demands (the SPLA, the government and the international community). All three refused to allow the SLA access to the negotiations: neither the SPLA nor the government would have benefited from splitting the winnings with a third party; the international community refused to allow them to join for fear of sacrificing peace between the north and south. "There was never a possibility that the Darfuris would be at the table. They would have known this; everyone did," stated Peter Schumann, former senior UN official in Sudan (personal interview, April 2008). ${ }^{58}$ However, as detailed above, some evidence outlined in this research indicates the SLA believed the government would negotiate a separate power-sharing framework with Darfuris, and that the international community would enable this process (Mohamed Baraka: personal interview, August 2007). The SLA's efforts to communicate with diplomats at Naivasha and with international NGOs ahead of the rebellion are consistent with this idea. Nevertheless, the rebels' strategic vision indicates they believed that military strength was necessary to achieving their fair share of power and wealth at

\footnotetext{
${ }^{58}$ Majtenyi (2004) reports that Abdelwahid Mohammed al-Nur requested a seat at Naivasha in April 2004. This request may be explained by political inexperience, or the fact that the rebels relationship with the international community had changed at that time, a point examined later. In the same article, Majtenyi (2004) quotes General Lazaro Sumbeiywo, the Kenyan mediator of the Naivasha peace talks, as saying that bringing the Darfur rebels into the talks at this point was not feasible.
} 
the negotiation table.

It is important to recall some evidence which undermines the claim that the rebellion in Darfur was precipitated by the Naivasha negotiations. As detailed in Chapter 2, the SLA rebel leaders had been preparing for this rebellion since the mid-1990s. In addition, the SLA's first attack against government outposts (in June 2002) - an expression of their strategic vision - occurred one month before the Machakos Protocol was signed. They therefore instigated conflict before the "negotiated settlement incentives" were present. Finally, it is relevant to remember another rebellion in Darfur: the 1991 insurrection led by Daud Bolad, the "father of the SLA" (Abdalla Adam Khatir: personal interview, August 2007). Bolad launched rebellion for similar reasons and with a similar strategy as the SLA at a time when the prospect of international intervention did not exist, nor did the expectation of a negotiated settlement. ${ }^{59}$ Rather, his efforts appear to have been an expression of the belief that violence was the only means to political ends in Sudan. A preliminary assessment of the timing of Bolad's rebellion suggests there was no obvious contextual trigger, implying the same could be true of the most recent rebellion in Darfur. As discussed in this research, frustration abounded and Darfuris were ready for rebellion in 2002/2003. Respondent 21, an SLA fighter with whom I spoke on 8 and 9 August 2007, vigorously stated:

\begin{abstract}
Why did we attack the government? We fought to take back what was ours. Fighting the government was the only way. The government and the Janjaweed were killing civilians before we attacked, ethnically targeting them. The government was the source of the killing. They and the Janjaweed were burning villages and killing our people with guns, mostly in north and west Darfur. We wanted to save the citizens from the fighting. (Personal interview, August 2007)
\end{abstract}

This evidence suggests the timing of the rebellion in Darfur was not strictly dictated by

\footnotetext{
${ }^{59}$ Daud Bolad rebelled in 1991; the last major peace agreement was in 1972 between the north and the Anya Nya, the south Sudanese rebel movement.
} 
events outside of the region.

A preliminary examination of the hypothesis linking the timing of the rebellion in Darfur to the Naivasha peace negotiations reveals some supporting evidence. The talks appear to have had a demonstration effect, reinforcing a long-held truth that fighting is the only way for marginalized regions to gain access to their fair share of power and wealth in Sudan. The negotiations may also have led the rebels to believe the military capabilities necessary to credibly threaten the government were less than they would have been otherwise because the SLA needed only to "spoil" the north-south peace. Finally, the international involvement at Naivasha appears to have led the SLA to believe these actors would assist with power-sharing negotiations. The occurrence of the Naivasha talks appears to better explain the timing of the rebellion than strictly the prospect of international intervention.

\subsubsection{Moral hazard after the onset of conflict}

Although not the object of this investigation, the SLA rebels' expectations of the international community appear to have changed over the course of the conflict. While they did not expect intervention to enable victory at its onset, international attention to the humanitarian catastrophe appears to have perversely influenced the behaviour of the rebel groups. Dr. Mudawi Ibrahim Adam summarized the behaviour pattern he witnessed:

The international attention led some, the SLA leaders, to believe that they didn't need military capabilities. They thought political negotiation with the [international] envoys was going to be enough. They were no longer looking for legitimacy through their people, but rather from the international community. They did not do their homework! International legitimacy has not proven enough. The rebels do not have the military capacity, nor do they have the political capacity to negotiate [with the government] or navigate the international community. (Personal interview, August 2007)

In fact, Belloni (2006) argues compellingly that international attention to Darfur after the 
onset of the conflict (in late 2003/2004) created a moral hazard for the rebel group, which is consistent with my data on rebel behaviour during that time. He suggests that the international rhetorical interest and condemnation of the "genocide" that occurred in late $2003^{60}$ led the rebel movements to mistake condemnation of Khartoum for support for their cause, emboldening them to increase their attacks and to harden their negotiating positions (Belloni 2006, 336). Belloni presents some evidence the rebels intentionally provoked violence against civilians because they "hoped that increasing fighting and visible destruction caused by government forces or government-sponsored groups such as the Janjaweed would attract international sympathy and thus trigger intervention against Khartoum" $(2006,337)$. The international community thus inadvertently encouraged the continuation of violence after its outbreak. This is a text-book example of the fraudulent behaviour hypothesized by Kuperman (2005, 2006, 2008a, 2008b).

\section{Conclusion}

Inexperience combined with military bravado, the perception of a weak military opponent, a new payoff structure and international rhetoric on human rights and negotiated settlements appears to have been a potent mix for Darfur. The Darfuri rebels seized the alignment of these factors to launch a rebellion against the government. They believed they needed to threaten the government militarily to achieve success. The foco theory of rebellion appears to describe why they believed the justice of their cause would enable victory despite the sub-optimal military context. The Naivasha peace negotiations also appear to have reinforced the idea that Darfuris' only means of achieving wealth and

\footnotetext{
${ }^{60}$ See Prunier (2005) for a discussion of the international rhetorical attention to Darfur, and Petersen and Tullin (2006) for a meticulous study of international reporting on the conflict.
} 
security was conflict. Evidence suggests that it is the occurrence of the negotiations that created a moral hazard for the Darfuri rebels, more than the international community's involvement in these negotiations. The rebels do not appear to have expected the international community to been sufficient to enable rebel victory (to extract power and wealth concessions from the government of Sudan). Given the international community's role in the occurrence of the negotiations, it may nevertheless have created indirect remote - moral hazard, which I will address in the Conclusion.. 


\section{CONCLUSION}

\section{Introduction}

This project started with the question: why did the SLA rebel leaders choose to rebel in conditions that were grossly unfavourable to their success, at great risk to themselves and their civilian support base? The objective was to assess whether Kuperman's (2005, $2006,2008 \mathrm{a}, 2008 \mathrm{~b}$ ) theory of moral hazard of humanitarian intervention provides a compelling answer. That is to say, whether evidence suggests that international humanitarian intervention created a moral hazard that altered the strategic incentives of the Sudan Liberation Army/Movement; and whether, as a result, the rebel group's leaders intentionally launched a suicidal rebellion against the government of Sudan in early 2003 because they believed international humanitarian intervention would enable victory at tolerable cost.

I chose to assess one of two scenarios Kuperman's theory hypothesizes: "fraudulent behavior"'. In addition, I focused my research on the Sudan Liberation Army/Movement (SLA), one of the two rebel groups that instigated conflict in 2003 in Darfur, in order to simplify my analysis without undermining its validity. The hypothesis implies that the SLA leaders did not believe they could achieve their political objectives on their own, but did believe victory was possible with international involvement in the crisis. From the perspective of the rebels, the actors involved in the north-south crisis (US, UK, UN, IGAD) were the "potential intervenors". The SLA rebels' strategic intention would have been to provoke genocidal violence against the people of Darfur in order to garner the attention and support of international actors. The assumption of intervention would have been based on the norm of international humanitarian intervention and the precedent set 
by international involvement in the north-south negotiations. The rebels would have believed the international community would enable SLA victory by artificially inflating the strength of the rebels relative to the government and pressuring the government for a negotiated settlement. Given the presence of long-standing grievances in Darfur, the hypothesis predicts that the rebellion would likely occur as soon as the rebels believed the international community would intervene, believed their military capabilities could resist immediate annihilation, and had the ability to communicate details of the crisis to the international community.

I tested the assumptions and predictions implicit in this hypothesis against data I collected and triangulated with evidence from other researchers and news sources from 2001-2004. In his 2008 article published in International Studies Quarterly, Kuperman claims the conflict in Darfur "demonstrates that the scope of moral hazard [of humanitarian intervention] is widespread and persistent, [...] even outside the Balkans and after $9 / 11 . "$ He claims that moral hazard explains both the occurrence and timing of the conflict in Darfur, as well as the continuation of violence after its outbreak. My findings nuance and challenge his first claim for a number of reasons.

\section{The findings}

This research suggests that the causal mechanism implicit in Kuperman's model does not provide a detailed and nuanced understanding of why Darfuri rebels chose to rebel in 2003. In fact, the rebellion in Darfur appears to largely fall outside of the scope of the moral hazard of humanitarian intervention because the rebels "expected victory at tolerable cost without international intervention". Therefore, technically, the theory does not purport to explain the puzzle of the rebellion. 
Nevertheless, the research project does improve the historical explanation of the conflict. The limited evidence I was able to gather indicates the rebellion in Darfur was not suicidal. The evidence has allowed me to preliminarily suggest the rebels' behaviour was consistent with the foco theory of rebellion, ideas which appear to have shaped, and ultimately distorted, SLA assessments of their military capabilities relative to the government. In particular, qualitative data suggests the rebels did not anticipate the government's counter-insurgency strategy which targeted civilians. The humanitarian catastrophe that resulted from the rebellion was thus unanticipated and, therefore, unintended by the SLA leaders.

Elsewhere, the evidence I have analysed suggests a weak causal link between the international involvement in the Naivasha negotiations and the rebellion in Darfur. While the SLA leaders appear to have expected the international community to intervene in Darfur and benefit their struggle, in early 2003, they did not believe international intervention would be sufficient to enable their victory. The rebel leaders appear to have recognised that only military strength would enable them to extract significant concessions from the government of Sudan.

My evidence tentatively suggests a causal link between the rebellion in Darfur and the occurrence of the Naivasha peace negotiations. The peace negotiations between the north and the south came about as a result of several factors: power-shifts within the National Congress Party, military exhaustion on both sides, and international pressure to negotiate (Kenny 2004). The occurrence of the negotiations appears to have been perceived by the Darfuri rebels as an ideal time to rebel for several reasons. The negotiations appear to have reinforced the notion that violence was an effective means to political victory. In addition, they signalled that the Sudanese military was weak and unable to confront 
another foe. Elsewhere, Naivasha may have led the rebels to believe insurrection would allow them to "spoil" the negotiations, decreasing the strength needed to achieve victory, although evidence suggests they would have known that there was no prospect of them being granted a seat at Naivasha. Finally, the SLA's efforts to generate international interest and intervention before the onset of the conflict suggests they believed the international actors involved in the north-south talks would intervene to their benefit, albeit in a limited capacity. An underlying motivating factor also would have been the fact that decisions that would shape the governance structures of the country - and thus the distribution of power and wealth - were being taken without Darfuris. These findings echo the claims of several researchers and practitioners (Straus 2005; ICG 2004; Tanner and Tubiana 2007; Power 2004; Prunier 2005; Belloni 2006).

Because international diplomatic and economic pressure - most significantly from the United States - was a contributing factor to the occurrence of the Naivasha negotiations, the international community's policies are one of several indirect contributing factors to the outbreak of conflict in Darfur. This appears to be a case of indirect moral hazard. Some researchers contend the indirect nature of this causal relationship unduly stretches the definition of moral hazard and, therefore, should not qualify (Crawford 2005; Rauchhaus 2005). Given that the available qualitative data suggests the rebels were not seeking to fraudulently or irresponsibly exploit the international community's good intentions, I would argue that the moral hazard of humanitarian intervention is not present in this case. For these reasons, Kuperman's theory of the moral hazard of humanitarian intervention does not compellingly explain the occurrence and timing of the rebellion in Darfur. 


\section{Limits of this research}

With regard to the objective of this research, my findings are limited by several factors. Research on decision-making is notoriously difficult (Geva and Mintz 1997). In addition, the context in which I collected evidence was risky, key participants were difficult to access and likely did not share with me some sensitive information on the intentions of the SLA leaders. Given the scope of this research, I chose to limit my analysis to the SLA's decision-making process at the onset of the conflict.

My contribution to the historical understanding of the onset of the conflict in Darfur is therefore limited, although still useful. Additional qualitative evidence, notably collected through in person interviews with surviving rebel leaders, would improve the detail and nuance of this analysis. Future research should also analyse JEM's decision-making process at the onset of the conflict and how the relationship between these two rebel groups impacted the occurrence and timing of the rebellion. In addition, while rational choice theory's predictive power remains unrivalled (Levy 1997), the unitary rational actor assumption limits the accuracy of this analysis. Further investigation of the rebel decision-making process would allow for a more detailed analysis and may reveal that alternative decision-making theories more compellingly characterise the SLA leadership's decision-making modus operandi at the onset of the conflict (as well as more generally the behaviour of both the SLA and JEM), notably organizational theories (Mintz 1997, 2). A detailed investigation of the rebel leaders' revolutionary influences, perhaps testing the explanatory power of the foco theory of rebellion, would be relevant in this regard, in addition to providing a novel perspective on this conflict.

Elsewhere, I am unable to draw plausible inferences about the validity and scope of the theoretical framework of the moral hazard of humanitarian intervention based on this 
research due to its design: a single case study is not a credible means to test the validity of a theory as a whole. As detailed in Chapter 4 , future research should be designed to "build" (improve) Kuperman's theory. While this was not the objective, coupled with other case-studies of moral hazard of humanitarian intervention, this case study could be useful in this regard.

\section{Policy implications}

Understanding why rebels instigate rebellions when they do is necessary to develop appropriate and effective policy tools to avert humanitarian disasters. Nevertheless, policy implications for the international community are not obvious in this case. The case-study highlights the complexity of the crisis in Darfur and the multiple causal paths that led to its occurrence. It also underscores the limited impact the international community had on triggering this conflict. As I will detail below, it is unclear how the international community could have averted the crisis in Darfur.

First, the international community clearly signalled to the Darfuris that they would not assist them should they launch a rebellion. Second, it is difficult to argue that the international community should not have become involved in the negotiated resolution of the devastating north-south conflict for fear of sparking rebellion elsewhere. Yet international actors may have had some room to manoeuvre. Fabrice Weissman, a former Head of Mission for Médecins Sans Frontières in Darfur, states: "the international community was deliberately ignoring the Darfur crisis in order to preserve the north-south peace process" (Weissman 2007). Belloni argues that "an early acknowledgment of Darfur's deteriorating situation could have led to effective preventive action. The 
inclusion of Darfur in the peace settlement between Khartoum and the SPLA/M could have constituted a successful conflict prevention strategy" $(2006,335)$.

Effective policy recommendations must take into account the power structures in Sudan and the incentives of the key actors. All indications suggest the inclusion of Darfur at Naivasha was never a possibility (Peter Schumann: personal interview, April 2008). The Darfuris were not a threat to the government, and the SPLA was unwilling to split its winnings with a group of young rebels that had not put in their time fighting the government (Edward Leno, Gibril Ibrahim: personal interviews, August 2007; Johnston 2007, 369). In addition, international calls to include the Darfuris at Naivasha would have served little purpose as international influence over the parties to the peace process was limited and fears of derailing the latter were well founded (Reeves 2009).

On 25 June 2003, near the beginning of the conflict in Darfur, the International Crisis Group recommended the following:

There is a real potential for those who feel ignored by the Inter-Governmental Authority on Development (IGAD) peace process to undermine any deal that is between only the Khartoum government and the rebel Sudan People's Liberation Army (SPLA). It is therefore incumbent upon the IGAD mediation team and the international observer countries to ensure that the grievances driving conflict in these areas are fully dealt with in any comprehensive peace deal. $(2003,1)$

In fact, this advice was largely followed. The Comprehensive Peace Agreement did set the foundations to end the marginalization of all regions of Sudan, including Darfur. The argument implies that such action would have deterred the Darfuri rebels from rebelling had it been undertaken earlier. Yet the rebels were unlikely to have been convinced by the international community to pursue their objectives through peaceful means, as these had borne little fruit in the past. The young men who chose to rebel appear to have been blinded by bravado and convinced peaceful means would not achieve their political objectives. 
Ironically, the rebellion in Darfur has slowed the implementation of the agreement by diverting international attention and resources away from the north-south axis. Darfur has become a spoiler, but doing so has harmed, rather than helped, its interests. Greater reassurances from the international community that the CPA would benefit them may have averted the crisis. Immediately mitigating Garang's encouragement and limited material support for rebellion in Darfur may also have mitigated disaster.

As a final note, it is important to nuance a suggestion made in Chapter 5, that a "competent Darfuri rebel" would have chosen to not instigate conflict against the government. The conditions in which the SLA rebelled were far from optimal and the naïveté, lack of preparedness and absence of a coherent political vision should be condemned given the human consequences of this rebellion. It is difficult to imagine, though, optimal conditions for rebellion in Darfur; ex post facto, all conditions could be argued to be sub-optimal, especially in when it is hard to justify conflict at the periphery as a means to threaten the center in Sudan (outside of the foco theory) (de Waal 2007, 27). Given the propensity for conflict as a means to political ends and the fact that the "pie was being divided" in Naivasha, from the perspective of the Darfuri rebels, the exceptional alignment of stars surrounding the north-south peace negotiations could rationally have been optimal, all the more so in light of their likely revolutionary influences. 


\section{ANNEX 1: LIST OF PARTICIPANTS: All interviews were conducted in English unless indicated otherwise.}

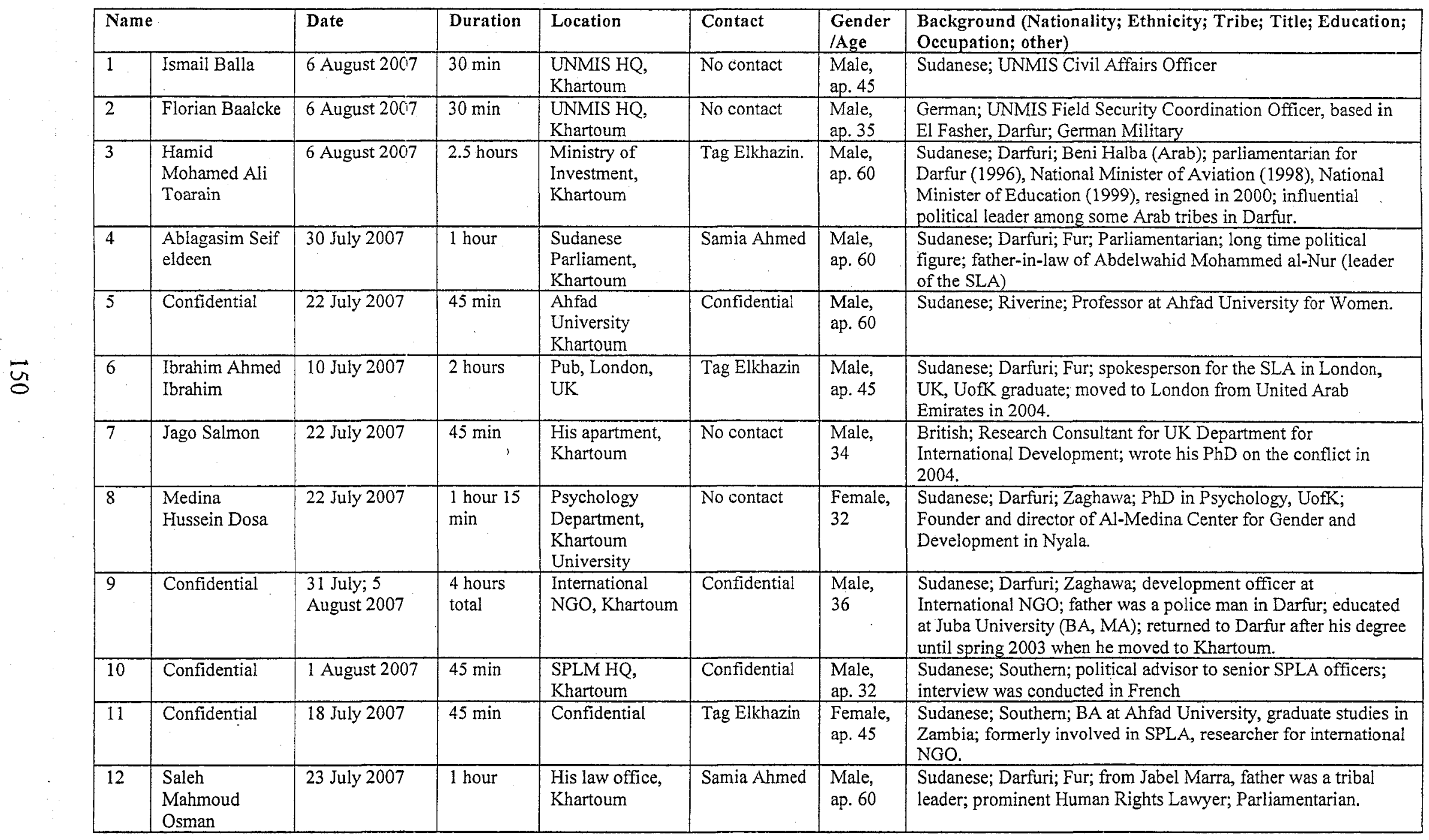




\begin{tabular}{|c|c|c|c|c|c|c|c|}
\hline 13 & Samia Ahmed & 18 July 2007 & 1 hour & $\begin{array}{l}\text { Canadian } \\
\text { Consulate, } \\
\text { Khartoum }\end{array}$ & Tag Elkhazin & $\begin{array}{l}\text { Female, } \\
\text { ap. } 35\end{array}$ & $\begin{array}{l}\text { Sudanese; Riverine; Consular/Human Security Officer at } \\
\text { Canadian Consulate in Khartoum; social justice activist, director } \\
\text { of Sudan Nile Trip. Extremely well connected with influential } \\
\text { groups in Khartoum. }\end{array}$ \\
\hline 14 & Tag Elkhazin & $\begin{array}{l}12 \text { June; } 30 \\
\text { July } 2007\end{array}$ & $\begin{array}{l}2 \text { hours } \\
\text { total }\end{array}$ & $\begin{array}{l}\text { Ottawa; Café, } \\
\text { Khartoum }\end{array}$ & No contact & $\begin{array}{l}\text { Male, } \\
\text { ap. } 55\end{array}$ & $\begin{array}{l}\text { Sudanese; Riverine; Engineer, UofK graduate; lived in Canada } \\
\text { for past } 20 \text { years; director of the Subsahara Center, does } \\
\text { research/policy on conflict/development in Sudan. }\end{array}$ \\
\hline 15 & Confidential & $\begin{array}{l}18 \text { July; } 9 \\
\text { August } 2007\end{array}$ & $\begin{array}{l}2 \text { hours } \\
\text { total }\end{array}$ & Confidential & Confidential & $\begin{array}{l}\text { Female, } \\
28\end{array}$ & $\begin{array}{l}\text { Sudanese; Darfuri; Arab; founded NGO in Nyala; interview in } \\
\text { Arabic: translator provided by her. }\end{array}$ \\
\hline 16 & Confidential & 17 July 2007 & 1 hour & $\begin{array}{l}\text { My apartment, } \\
\text { Khartoum }\end{array}$ & Confidential & $\begin{array}{l}\text { Male, } \\
\text { ap. } 35\end{array}$ & $\begin{array}{l}\text { Sudanese; Riverive; UofK graduate; community/social justice } \\
\text { activist, politically involved. }\end{array}$ \\
\hline 17 & $\begin{array}{l}\text { Abdalla Adam } \\
\text { Khatir }\end{array}$ & $\begin{array}{l}26 \text { July; } 1,10 \\
\text { Aug. } 2007\end{array}$ & 3 hours & $\begin{array}{l}\text { Hotel restaurant, } \\
\text { Khartoum }\end{array}$ & Tag Elkhazin & $\begin{array}{l}\text { Male, } \\
\text { ap. } 60\end{array}$ & $\begin{array}{l}\text { Sudanese; Darfuri; Fur; UofK and Omdurman Islamic } \\
\text { University; journalist, beginning of his career worked for } \\
\text { Khartoum government, later becomes supporter of the National } \\
\text { Democratic Alliance. }\end{array}$ \\
\hline 18 & Safaa Elghagib & 12 July 2007 & $45 \mathrm{~min}$ & $\begin{array}{l}\text { Center for } \\
\text { Development } \\
\text { Assistance }\end{array}$ & No contact & $\begin{array}{l}\text { Female, } \\
\text { ap. } 40\end{array}$ & $\begin{array}{l}\text { Sudanese; Darfuri; Founder and Director of Center for } \\
\text { Development Assistance, organization focused on inter-tribal } \\
\text { relations/development in Darfur, founded in } 1999 .\end{array}$ \\
\hline 19 & $\begin{array}{l}\text { Bashura Hassan } \\
\text { El Taher }\end{array}$ & 9 August 2007 & 4 hours & $\begin{array}{l}\text { His office, } \\
\text { Khartoum. }\end{array}$ & Confidential & $\begin{array}{l}\text { Male, } \\
\text { ap. } 40\end{array}$ & $\begin{array}{l}\text { Sudanese; Darfuri; Zaghawa; Secretary of Training and Capacity } \\
\text { Building for the Sudan Liberation Movement (Mini Minawi's } \\
\text { faction, in Khartoum since signing of DPA); he was head of } \\
\text { internal security for SLA; BA from El Fashir University; MA } \\
\text { and PhD (ongoing) from UofK. }\end{array}$ \\
\hline 20 & Edward Leno & 7 August 2007. & 1 hour & $\begin{array}{l}\text { SPLM HQ, } \\
\text { Khartoum }\end{array}$ & Samia Ahmed & $\begin{array}{l}\text { Male, } \\
\text { ap. } 60\end{array}$ & $\begin{array}{l}\text { Sudanese; southern Sudanese; former Head of Security for the } \\
\text { SPLA, top SPLA officer, heading SPLM Darfur effort. }\end{array}$ \\
\hline 21 & Confidential & $\begin{array}{l}8,9 \text { August } \\
2007 .\end{array}$ & 2 hours & $\begin{array}{l}\text { Hotel; Café, } \\
\text { Khartoum }\end{array}$ & $\begin{array}{l}\text { Nuala Lawlor, } \\
\text { Political } \\
\text { Affairs } \\
\text { Officer, } \\
\text { Canadian } \\
\text { Consulate, } \\
\text { Khartoum } \\
\end{array}$ & $\begin{array}{l}\text { Male, } \\
40\end{array}$ & $\begin{array}{l}\text { Sudanese; Darfuri; Fur; SLA fighter, had recently signed a peace } \\
\text { agreement with the government. Interview in Arabic, translator } \\
\text { provided by participant. }\end{array}$ \\
\hline 22 & $\begin{array}{l}\text { General Henry } \\
\text { Anyidoho }\end{array}$ & 4 August 2007 & $45 \mathrm{~min}$ & $\begin{array}{l}\text { UNMIS HQ, } \\
\text { Khartoum }\end{array}$ & $\begin{array}{l}\text { Senator } \\
\text { Romeo } \\
\text { Dallaire } \\
\end{array}$ & $\begin{array}{l}\text { Male, } \\
60\end{array}$ & $\begin{array}{l}\text { Ghanaian; UN Deputy Joint Special Representative, UNMIS; has } \\
\text { worked for mission since } 2005\end{array}$ \\
\hline 23 & Melinda Young & 9 August 2007 & $30 \mathrm{~min}$ & Café, Khartoum & No contact & $\begin{array}{l}\text { Female, } \\
\text { ap. } 35\end{array}$ & $\begin{array}{l}\text { Australian; Humanitarian Coordinator for Oxfam, was in Darfur } \\
\text { from March-July 2004; came back in February } 2007 \text {. }\end{array}$ \\
\hline 24 & $\begin{array}{l}\text { Mudawi } \\
\text { Ibrahim Adam }\end{array}$ & $\begin{array}{l}30 \text { July; } 8 \\
\text { August } 2007\end{array}$ & $\begin{array}{l}1 \text { hour } 45 \\
\text { min }\end{array}$ & $\begin{array}{l}\text { SUDO offices, } \\
\text { Khartoum }\end{array}$ & $\begin{array}{l}\text { John Young, } \\
\text { researcher } \\
\text { with Snill } \\
\text { Arms Survey. }\end{array}$ & $\begin{array}{l}\text { Male, } \\
60\end{array}$ & $\begin{array}{l}\text { Sudanese; Kordofan; Director of SUDO, Sudanese } \\
\text { developmenthumanitarian NGO; social justice activist/political } \\
\text { dissident; works with a number of international funders; travels } \\
\text { to international conferences. }\end{array}$ \\
\hline
\end{tabular}




\begin{tabular}{|c|c|c|c|c|c|c|c|}
\hline 25 & $\begin{array}{l}\text { Hassan al- } \\
\text { Turabi }\end{array}$ & $\begin{array}{l}31 \text { August } \\
2007\end{array}$ & 3 hours & $\begin{array}{l}\text { His home, } \\
\text { Khartoum }\end{array}$ & Samia Ahmed & $\begin{array}{l}\text { Male, } \\
75\end{array}$ & $\begin{array}{l}\text { Sudanese; Riverine; prominent political/spiritual leader since } \\
\text { 1964; political dissident; under house arrest in Aug. } 2007 .\end{array}$ \\
\hline 26 & Confidential & 7 August 2007 & $30 \mathrm{~min}$ & Confidential & Confidential & $\begin{array}{l}\text { Female, } \\
\text { ap } 35\end{array}$ & $\begin{array}{l}\text { Sudanese; Darfuri; Arab; former political figure in Darfur; } \\
\text { interview in Arabic, translated provided by participant. }\end{array}$ \\
\hline 27 & Phil Cox & $\begin{array}{l}12 \text { August } \\
2007\end{array}$ & $\begin{array}{l}\text { lhour } 15 \\
\text { min }\end{array}$ & $\begin{array}{l}\text { His studio in } \\
\text { East London, } \\
\text { UK }\end{array}$ & Confidential & $\begin{array}{l}\text { Male, } \\
\text { ap. } 32\end{array}$ & $\begin{array}{l}\text { British; director of Nature Voice Films media/film company; has } \\
\text { worked on several conflict zones; traveled to Darfur } \\
\text { clandestinely in late } 2003 \text { with the help of SLA contact. }\end{array}$ \\
\hline 28 & Gibril Ibrahim & $\begin{array}{l}13 \text { August } \\
2007\end{array}$ & 2 hours & $\begin{array}{l}\text { His apartment, } \\
\text { London UK }\end{array}$ & Tag Elkhazin & $\begin{array}{l}\text { Male, } \\
\text { ap. } 50\end{array}$ & $\begin{array}{l}\text { Sudanese; Darfuri; Zaghawa; University of Khartoum (1979), } \\
\text { MA/PhD in Economics in Japan; Senior JEM leader, brother of } \\
\text { Khalil Ibrahim (founder and leader of JEM); author of the Black } \\
\text { Book; exiled in London since } 2005 \text {. }\end{array}$ \\
\hline 29 & $\begin{array}{l}\text { Hafiz } \\
\text { Mohammed }\end{array}$ & $\begin{array}{l}13 \text { August } \\
2007\end{array}$ & 1 hour & $\begin{array}{l}\text { Justice Africa, } \\
\text { London, UK }\end{array}$ & $\begin{array}{l}\text { Abdalla } \\
\text { Adam Khatir }\end{array}$ & $\begin{array}{l}\text { Male, } \\
\text { ap. } 45\end{array}$ & $\begin{array}{l}\text { Sudanese; Darfuri; Fur; Director of Sudan affairs for Justice } \\
\text { Africa, based in London; }\end{array}$ \\
\hline 30 & $\begin{array}{l}\text { Liz Hodgkin } \\
\text { and Benedict } \\
\text { Goderia }\end{array}$ & $\begin{array}{l}14 \text { August } \\
2007\end{array}$ & 1 hour & $\begin{array}{l}\text { Restaurant, } \\
\text { London, UK }\end{array}$ & No contact & $\begin{array}{l}\text { Female, } \\
\text { ap. } 60 \text {; } \\
\text { Female, } \\
\text { ap. } 30\end{array}$ & $\begin{array}{l}\text { Hodgkin: British; Director at AI Headquarters; spent the past } 30 \\
\text { years working in and on Sudan. Goderia: British; mid-level staff } \\
\text { at Al; both travelled to Darfur in early } 2003 \text { to document human } \\
\text { rights abuses. }\end{array}$ \\
\hline 31 & $\begin{array}{l}\text { Mohammed } \\
\text { Baraka }\end{array}$ & $\begin{array}{l}15 \text { August } \\
2007\end{array}$ & 2 hours & $\begin{array}{l}\text { Coffee shop, } \\
\text { London, UK }\end{array}$ & $\begin{array}{l}\text { Abdalla } \\
\text { Adam Khatir }\end{array}$ & $\begin{array}{l}\text { Male, } \\
\text { ap. } 60\end{array}$ & $\begin{array}{l}\text { Sudanese; Darfuri; Fur; Islamic University of Omdurman, } \\
\text { became an National Congress Party Parliamentarian Darfur in } \\
\text { 2001, member of the government's delegation that negotiated } \\
\text { with rebels in 2002/2003; currently exiled in UK }\end{array}$ \\
\hline 32 & Confidential & $\begin{array}{l}15 \text { August } \\
2007\end{array}$ & 1.5 hours & $\begin{array}{l}\text { Hotel, London, } \\
\text { UK }\end{array}$ & Phil Cox & $\begin{array}{l}\text { Male, } \\
\text { ap. } 30\end{array}$ & $\begin{array}{l}\text { Sudanese; Darfuri; Fur; activist associated with rebel } \\
\text { movements; based in London. }\end{array}$ \\
\hline 33 & Peter Schuman & 11 April 2008 & $30 \mathrm{~min}$ & Pub, Ottawa & $\begin{array}{l}\text { No contact. } \\
\text { Peacebuild } \\
\text { Conference, } \\
\text { 10-11 April } \\
2008 \text {, Ottawa }\end{array}$ & $\begin{array}{l}\text { Male, } \\
\text { ap. } 60\end{array}$ & $\begin{array}{l}\text { German; a former UNDP staff member with extensive } \\
\text { experience in Sudan; former the Regional Coordinator and } \\
\text { Representative of the UNMIS in Southern Sudan. }\end{array}$ \\
\hline 34 & Confidential & $\begin{array}{l}20 \text { August } \\
2008\end{array}$ & 1 hour & $\begin{array}{l}\text { New York City, } \\
\text { USA }\end{array}$ & Confidential & $\begin{array}{l}\text { Male, } \\
\text { ap. } 35\end{array}$ & Former mid-level UN officer in Darfur. \\
\hline 35 & Confidential & $\begin{array}{l}20 \text { August } \\
2008\end{array}$ & $30 \mathrm{~min}$ & $\begin{array}{l}\text { Phone } \\
\text { conversation }\end{array}$ & Confidential & $\begin{array}{l}\text { Male, } \\
\text { ap. } 60\end{array}$ & $\begin{array}{l}\text { Former senior individual associated with UN work in Darfur } \\
\text { from } 2005 \text { to } 2008 \text {. }\end{array}$ \\
\hline
\end{tabular}


Kelly Whitty

Masters Candidate

Norman Paterson School of International Affairs

Student number: 100713375

(613) 564 0624; (613) 2906364

Kelly.whitty@gmail.com

February 2008

Carleton University Research Ethics Committee

Dear Committee members,

I am a masters candidate at the Norman Paterson School of International Affairs (anticipated 2008). During the summer of 2007, while I was not a registered student, I had the opportunity to travel to Khartoum, Sudan, and London, England. While in Khartoum and London I collected data which I would like to use towards my thesis. The present pertains to the ethics of this research.

I traveled to Khartoum and London in July and August 2007. The object of my travels was to learn about the conflict in Darfur from Sudanese, having worked on issues relating to the conflict for over a year and a half at the Senate of Canada. My visa was sponsored by Ahfad University for Women, Khartoum, where I worked as a volunteer on micro-credit programs for Darfurian women in Internally Displaced Persons camps on the outskirts of the city.

In early 2003, two rebel movements in Darfur, Sudan, launched a full-scale rebellion against the Government of Sudan with little apparent chances of success. While in Khartoum, I had the opportunity to conduct research on why the rebel leadership decided to launch the rebellion when they did. I did not apply for, and was not granted an ethics approval for the research because I was not a registered student. Nevertheless, while conducting the interviews, I respected the Carleton University Research Ethics Guidelines in the strictest way possible.

I conducted 30 interviews in person in Khartoum between 11 July and 10 August, 2007. I interviewed Sudanese Government Officials, parliamentarians, journalists, academics, members of civil society, rebel leaders and rebel fighters. I also interviewed one Sudanese United Nations personnel, one international United Nations personnel and one international non-governmental-organization (NGO) staff. The interviews were openended, based on a set of core questions, and ranged from thirty minutes to two hours.

At the beginning of each interview, I reviewed verbally the attached letter of information and consent, point my point. The participants then voiced any concerns or questions, which I responded to. They then gave their consent or not. I did not ask them to sign the letter because to do so would have put the participants at an unacceptable risk. 
Because of the oppressive nature of the political regime in Sudan, I did not feel it was in the participant's best interest for me to keep paper proof that they had spoken to me about potentially sensitive issues.

I conducted 5 interviews in London, England, between 12 August and 15 August, 2007. I interviewed Sudanese and British staff of international NGOs, and exiled members of the leadership of the Darfurian rebel movements. Before starting each interview, the participant reviewed and signed the attached letter of information and consent. Asking them to sign the letter did not present risks to their safety in London, England.

Despite not having been granted approval for the research I was conducting during the summer 2007, I believe I respected to my utmost ability the ethical standards that are so crucial to conducting research. I would therefore request that I be granted permission to use said research toward my Masters thesis.

I would be happy to answer any questions you may have regarding the above.

Sincerely,

Kelly Whitty 


\title{
ANNEX 3: LETTER OF INFORMATION AND CONSENT FORM
}

\author{
Re: Masters Thesis: \\ The Timing of the Rebellion in Darfur, Sudan
}

Principal Investigator

Kelly Whitty, Masters Candidate, Norman Paterson School of International Affairs

(NPSIA), Carleton University, 0910110883 or Kelly.whitty@gmail.com

Research Supervisor

Dr. James Ron, Associate Professor, Norman Paterson School of International Affairs

(NPSIA), Carleton University, (613) 5202600 Ext. 1369

Dear..........

I am conducting research, which may be used for my M.A. research essay on the reasons that propelled Darfurian rebel leaders to launch a full-scale rebellion against the Government of Sudan in 2002-2003.

I am contacting you for an interview in order to assist in the collection of expert and/or practitioner experiences and perspectives. Interviews will be open-ended, based on a set of core questions and themes, and will range from thirty minutes to two hours, depending on your availability and inclination. You may be requested to participate in a follow-up interview, and you have the right to accept or decline any such interview. At the time of the interview, your permission will be requested to takes notes by hand or on a laptop computer. The files will be stored securely and you may accept or decline this request at any point prior to or during the interview.

Because some questions in the interview may cover information that could be personally and/or professionally sensitive, you may at any time request your interview or portions of it to be confidential. In such cases, my thesis and related articles and/or presentations will attribute your responses to an anonymous source. You may, of course, also choose to decline to answer any question or to end the interview at any time. Please note that although I will keep your responses confidential if requested to do so, the small number of interviewees means that I may not be able to guarantee anonymity in terms of your participation.

All efforts will be made to conduct interviews in person or by phone. In extreme cases, electronic correspondence will be used, but in signing this consent form, you acknowledge that I cannot guarantee security of such information, as it is not a secure form of communication.

Physical notes taken during interviews will be destroyed securely (shredder) following transcription into electronic format, which will occur shortly after the interview. Electronic data (when applicable) will be immediately uploaded onto a system through an 
email address to which the researcher has sole access. All electronic copies of the data will be deleted from the researcher's personal computer once uploaded.

Your participation is greatly appreciated but the project does not provide compensation for participation. The main benefit you will obtain from this research is personal satisfaction that this issue is being examined from an academic perspective. The current literature retains little attention to the decision-making process that led to Darfurian rebel leaders launching a full-scale rebellion against the Government of Sudan in 2003. This project seeks to gain a more systematic understanding of the factors that led to this decision. Greater understanding of these factors may contribute to future conflict prevention.

\section{Consent}

Your participation in this research interview is appreciated. Participation as an interviewee is voluntary; you may decline participation or withdraw at any time. Should you choose to withdraw, the thesis and related articles and/or presentations will not use your responses in any way and all my notes will be destroyed.

Requests for confidentiality can be made in writing prior to, during or after the interview. Such requests must be made prior to submission dates for publication in order to be removed from that publication. The thesis submission date is August 2008; for other dates, please contact me directly. Should you have any questions or concerns prior to, during or after the interview, please contact me by email Kelly.whitty@gmail.com. You may also request an electronic copy of any publication based on the research findings.

Signing this consent form signifies that you agree that I may openly attribute your responses via quotations or restatements in the final thesis document, conference presentations and/or web, electronic or print articles related to the thesis research, unless otherwise specified as outlined above. By signing below, you agree that you have read and understand the above information regarding your role and rights as an interviewee.

$$
\text { Name of Participant }
$$

Signature

This consent form will be retained by me; a copy will be provided to you.

Kelly Whitty

MA Candidate -- International Affairs, Human Security

Norman Paterson School of International Affairs

Carleton University

Ottawa, Ontario, Canada

Kelly.whitty@gmail.com

kwhitty@connect.carleton.ca 


\section{BIBLIOGRAPHY}

Abdul-Jalil, M.A. 2006. The dynamics of customary land tenure and natural resource management in Darfur. Land Reform 2:9-23.

Abdul-Jalil, M.A., Adam Azzain Mohammed and Ahmed Yousif. 2007. Native Administration and Local Governance in Darfur: Past and Future. In War in Darfur, ed. De Waal, 39-67. Harvard: Harvard University Press.

Agence France Presse (AFP). 2003. Sudan's western rebels fear being wiped out after peace deal in south. Agence France Presse, 23 October 2003, Cairo.

Ahmad al-Nur, Al-Nur, Fa'iz al-Shaykh al-Salik and Nizar Daw-al-Na'im. 2003.

Sudanese opposition sources describe attack on western provinces capital. $A l$ Hayat, 26 April 2003: 1,6.

Amnesty International (AI). 2002. Fear for safety/ Torture and Ill-treatment/

Disappearance/Detention without charge/ Medical concern. AI Index: AFR 54/022/2002 23 August 2002 UA 261/02.

--- 2003. Fear for safety/fear of torture or ill-treatment/incommunicado detention AFR 54/066/2003, 30 July. UA 229/03.

--- 2004. Sudan, Darfur: Too Many People Killed for no Reason. AFR 54/008/2004.

Anderson, Scott. 2004. How Did Darfur Happen? New York Times Magazine, October 17.

Ayoob, Mohammed. 2001 Spring. Humanitarian Intervention and State Sovereignty. The international Journal of Human Rights 6 (1): 81-201.

Azzain Mohamed, Adam. 2007. The Comprehensive Peace Agreement and Darfur. In War in Darfur ed. Alex de Waal, 199-213. Harvard: Harvard University Press.

Babbie, Earl and Lucia Benaquisto. 2002. Fundamentals of Social Research: First Canadian Edition. Toronto: Nelson College Indigenous.

Baker, Tom. 1996. On the Genealogy of Moral Hazard. Texas Law Review 75 (2): $237-$ 292.

Barutciski, Michael, Astri Suhrke, Peta Sandison and Rick Garlock. 2000. The Kosovo Refugee Crisis: An independent evaluation of UNHCR's emergency preparedness and response. Geneva: United Nations High Commissioner for Refugees.

Belloni, Roberto. 2005. Is Humanitarianism Part of the Problem? Nine Theses. Cambridge: Belfer Center for Science and International Affairs. [Discussion Paper, March] 
--- 2006. The Tragedy of Darfur and the Limits of the 'Responsibility to Protect'. Ethnopolitics 5(4): 327-346.

Biernacki, Patrick, and Dan Waldorf. 1981. Snowball Sampling: Problems and Techniques of Chain Referral Sampling. Sociological Methods and Research 10: $141-63$.

Bernard, L. L. 1972. War and Its Causes. New York: Garland.

Black, David R and Paul D. Williams. 2008. Darfur's Challenge to International Society. Canadian International Council 65 (6): 1-23.

Bob, Clifford. 2001. Marketing Rebellion: Insurgent Groups, International Media, and NGO Support. International Politics 38: 311-334.

Boshoff, Henri. 2005. The African Union Mission in Sudan: Technical and operational dimensions. African Security Review 14 (3): 57-60.

Burr, J. Millard, and Robert Collins. 2007. Darfur: The Long Road to Disaster. Princeton: Princeton University Press.

Canadian Department of Foreign Affairs and International Trade (DFAIT). 2008. Minister Bernier Announces Major Canadian Engagement for Peace in Sudan. DFAIT New Service, 26 March.

Centre for Research on the Epidemiology of Disasters (CRED). 2008. Scientific evidence supports UN OCHA extrapolation on Darfur mortality. Press Release, 22 April.

Childs, Matt. 1995. A Historical Critique of the Emergence and Evolution of Ernesto Che Guevara's Foco Theory. Journal of Latin American Studies 27 (3): 593-624.

Cobham, Alex. 2005. Causes of Conflict in Sudan: Testing the Black Book. The European Journal of Development Research 17(3):462-480.

Cohen, Lenard. 1993. Broken Bonds: The Disintegration of Yugoslavia. Boulder: Westview Press.

Collier, Paul and Anke Hoeffler. 2004. Greed and Grievance in Civil War. Oxford Economic Papers 56: 563-595.

The Comprehensive Peace Agreement between the Government of the Republic of the Sudan and the Sudan People's Liberation Movement/Sudan People's Liberation Army, 09 Jan 2005.

Crawford, Timothy W. 2005. Moral hazard, intervention and internal war: A conceptual Analysis. Ethnopolitics 4(2): 175 - 193. 
Crawford, Timothy W. 2001. Pivotal Deterrence and the Kosovo War: Why the Hoolbrook Agreement Failed. Political Science Quarterly 116 (4): 499-523.

--- 2004. Moral Hazard Causal Arguments: A Conceptual and Methodological Appraisal. Paper presented at the annual meeting of the American Political Science Association, Sept. 2, Chicago.

Daalder, Ivo H., and Michael E. O'Hanlon. 1999. The Dollarization Debate: Unlearning the Lessons of Kosovo. Foreign Policy 116: 128-140.

Davies, James Chowning, ed. 1971. When Men Revolt and Why. New York: Free Press.

Davies, Philip. 2001. Spies as Informants: Triangulation and the Interpretation of Elite Interview Data in the Study of the Intelligence and Security Services. Politics 21 (1): 73-80.

Deng, Francis. 1995. War of Visions: Conflict of Identities in the Sudan. Brookings Institutions Press.

Deng, Francis, Donald Rothchild, I. William Zartman, Sadikiel Kimaro and Terrence Lyons. 1996. Sovereignty as responsibility: Conflict management in Africa. Washington D.C.: Brookings Institution.

Desai, Raj and Harry Eckstein. 1990. Insurgency: The Transformation of Peasant Rebellion. World Politics 42 (4): 441-465

Economist Intelligence Unit (EIU). 2009. Country Profile Sudan-Main Report. 4 March. The Economist.

Evans, Gareth. 2007. Making Idealism Realistic: The Responsibility to Protect as a New Global Security Norm. Presentation at the launch of the Stanford MA Program in International Policy Studies, 7 February 2007, Stanford University, California.

Fein, Helen. 1990. Genocide: A Sociological Perspective. Current Sociology 38: 1.

Freedman, Lawrence. 2007. Using Force for Peace in an Age of Terror. In Leashing the Dogs of War, ed. by Crocker, Hampson and Aall, 245-263. Washington: United States Institute of Peace.

Flint, Julie. 2007. Darfur's Armed Movements. In War in Darfur, ed. by Alex de Waal, 140-172. Harvard: Harvard University Press.

Geva, Nehemia and Alex Mintz. 1997. Decision making on war and peace: the cognitive rational debate. Colorado: Lynne Rienner Publishers.

George, Alexander L. and Andrew Bennett. 2005. Case Studies and Theory Development in the Social Sciences. Cambridge: MIT Press. 
Gilboa, Eytan. 2005. Global Television News and Foreign Policy: Debating the CNN Effect. International Studies Perspectives 6: 325-341.

Goodman, Peter S. 2004. China Invests Heavily In Sudan's Oil Industry. Washington Post, December 23, 2004, page A01.

Grigorian, Arman. 2005. Third-party intervention and escalation in Kosovo: Does moral hazard explain it? Ethnopolitics 4(2):195 - 213.

Guha-Sapir, D. and Olivier Degomme. 2005. Darfur: Counting the Deaths. Mortality Estimates from Multiple Survey Data. Brussels: CRED.

Gurr, Ted Robert. 1970. Why Men Rebel. Princeton: Princeton University Press.

Hackett, Kenneth. 2006. Silent tsunamis: forgotten humanitarian crises. America 194 (13): 17-19.

Haggar, Ali. 2007. The origins and Organization of the Janjiwiid in Darfur. In War in Darfur and the Search for Peace, ed. De Waal, 113-139. Harvard: Harvard University Press.

Hamilton, Rebecca. 2006. The Responsibility to Protect: from document to doctrine - but what of implementation? Harvard Human Rights Journal 19. http://www.law.harvard.edu/students/orgs/hrj/iss19/hamilton.shtml.

Hamilton, Rebecca and Chad Hazlett. 2007. "Not on our Watch": The Emergence of the American Movement for Darfur. In War in Darfur and the Search for Peace, ed. De Waal, 337-366. Harvard: Harvard University Press.

Harff, Barbara, and Ted Robert Gurr. 1988. Toward Empirical Theory of Genocides and Politicides. International Studies Quarterly 32(3): 359-371.

Herbst, Jeffrey. 2000. States and Power in Africa: Comparative Lessons in Authority and Control. Princeton: Princeton University Press.

Heuty, Antoine and Ruth Carlitz. 2009. Resource Dependence and Budget Transparency. Revenue Watch Institute. http://www.revenuewatch.org/news/020109a.php\# ftn1

Homer-Dixon, Thomas. 2007. Terror in the Weather Forecast. New York Times, 24 April, Editorial Desk.

Huth, Paul. 1999. Deterrence and International Conflict: Empirical Findings and Theoretical Debates. Annual Review of Political Science 2:25-48.

Human Rights Watch. 1999. The Popular Defence Forces and the University of Bahr El Ghazal. http://www.hrw.org/reports/1999/sudan/SUDAWEB2-20.htm 
Idris, Yousif B. 2000. The proliferation of small arms in Sudan (case of Dar Fur State). Presentation at the Ploughshares conference entitled "Improving Human Security through the Control and Management of Small Arms", 23-25 March, 2000, in Arusha, Tanzania.

Independent on Sunday. 2003. 52 Killed in Sudan Clash. Independent on Sunday, News, 27 April 2003, London, 4.

International Commission on Intervention and State Sovereignty (ICISS). 2001. The Responsibility to Protect, co-chaired by Gareth Evans and Mohamed Sahoun. Ottawa: Government of Canada.

International Committee of the Red Cross (ICRC). 1999. Background paper, Third Workshop on Protection, 7 January.

International Criminal Court (ICC). 2009. Warrant of Arrest for Omar Hassan Ahmad Al Bashir, ICC-02/05-01/09, 4 March. http://www.icccpi.int/iccdocs/doc/doc639078.pdf

The International Criminal Tribunal for the Former Yugoslavia (ICTY). 1999. Criminal indictment against Slobodan Milosevic, Case No IT-99-37.

International Crisis Group (ICG). 1998a. Kosovo Spring. Europe Report. Pristina, Sarajevo.

--- 1998b. Kosovo's Long Hot Summer: Briefing on Military, Humanitarian and Political Developments in Kosovo. Europe Report 41.

--- 2002a. God, Oil and Country: Changing the Logic of War in Sudan. Africa Report 39. Brussels.

--- 2002b. Capturing the Moment: Sudan's Peace Process in the Balance. Africa Report 42. Brussels.

--- 2003. Sudan's Other Wars. Africa Briefing, 25 June. Brussels.

--- 2004. Darfur Rising: Sudan's New Crisis. Africa Report 76. Nairobi/Brussels.

--- 2006. To Save Darfur. Africa Report 105. Brussels.

--- 2007a. Darfur's New Security Reality. Africa Report 134. Brussels.

--- 2007b. A Strategy for Comprehensive Peace in Sudan. Africa Report 130. Brussels.

Jane's Intelligence Review. 2008. Sudan Liberation Movement/Army (SLM/A). 23

September. [Jane's Online journal] 
Jane's Islamic Affairs Analyst. 2007. US-Arab intelligence co-operation. Jane's Information Group. [Jane's Online journal]

Jentleson, Bruce. 2007. Yet Again: Humanitarian Intervention and the Challenges of "Never Again". In Leashing the Dogs of War ed. by Crocker, Hampson and Aall, 277-297. Washington: United States Institute of Peace.

Johnson, Joshua. 2006. From Cuba to Bolivia: Guevara's Foco Theory in Practice. Innovations 6: 26-32.

Johnston, Patrick. 2007. Negotiated Settlements and Government Strategy in Civil War: Evidence from Darfur. Civil Wars 9 (4): 359-377.

Kamal el-Din, Ahmed. 2007. Islam and Islamism in Darfur. In War in Darfur, ed Alex de Waal, 92-112. Harvard: Harvard University Press.

Kenny, Garry. 2004. Surviving the Peace: Better Canadian responses to post-conflict transition needs in Africa. Presentation at the NGO-Canadian Government dialogue, 15 October, Ottawa.

The Khartoum Monitor. 2002. Sudan: US envoy says last round of peace talks "very successful". 22 November. BBC Monitoring: International Reports.

Kier, E. and Mercer, J. 1996. Setting precedents in anarchy: military intervention and weapons of mass destruction. International Security 20 (4): 77-106.

Kriesberg, Louis. 2007. Contemporary Conflict Resolution Applications. In Leashing the Dogs of War ed. by Crocker, Hampson and Aall, 255-276. Washington: United States Institute of Peace.

Kuperman, Alan J. and Timothy W. Crawford, editors. 2006. Gambling on Humanitarian Intervention: Moral Hazard, Rebellion and Civil War. Abingdon, England; New York: Routledge.

Kuperman, Alan J. 2005. Suicidal Rebellions and the Moral Hazard of Humanitarian Intervention. Ethnopolitics 4(2):149-173.

Kuperman, Alan J. 2008a. The Moral Hazard of Humanitarian Intervention: Lessons from the Balkans. International Studies Quarterly 52: 49-80.

Kuperman, Alan J. 2008b. Mitigating the Moral Hazard of Humanitarian Intervention:

Lessons from Economics. Global Governance 14: 219-240.

Lebow, R. N. 1981. Between Peace and War: The Nature of International Crises.

Baltimore, MD: John Hopkins University Press. 
Levy, Jack S. 1997. Prospect Theory, Rational Choice and International Relations. International Studies Quarterly 41: 87-112.

Majtenyi, Cathy. 2004. Sudanese Rebel Group Presses to be Included in Kenya Peace Talks. Voice of America, 17 May. http://www.voanews.com/english/archive/200405/a-2004-05-17-15-1.cfm

Martin, Joanne, Maureen Scully and Barbara Levitt. 1990. Injustice and the Legitimation of Revolution: Damning the Past, Excusing the Present, and Neglecting the Future Journal of Personality and Social Psychology 59 (2): 281-290.

Mintz, Alex. 1997. Foreign Policy Decisionmaking: Bridging the Gap Between the Cognitive Psychology and Rational Actor "Schools". In Decision-making on War and Peace, ed. Nehemia Geva and Alex Mintz, 1-11. Colorado: Lynne Rienner Publishers.

Morrow, James. 1997. A Rational Choice Approach to International Conflict. In Decisionmaking on War and Peace: the Cognitive-Rational Debate, ed. by Geva and Mintz. 12-32. Colorado: Lynne Rienner Publishers.

Murphy, Sean. 1996. Humanitarian Intervention: the United Nations in an Evolving World Order. Philadelphia: University of Pennsylvania Press.

North Atlantic Treaty Organization (NATO). 1999. NATO's role in relation to Kosovo. http://www.nato.int/kosovo/history.htm

Nuremburg Trial Proceedings. Trial of the Major War Criminals Before the International Military Tribunal, Nuremberg, 14 November 1945 - 1 October 1946. The Avalon Project, Yale Law School. http://avalon.law.yale.edu/imt/imtconst.asp\#art6

Olsen, Gorm Rye; Carstensen, Nils; Høyen, Kristian. 2003. Humanitarian Crises: What Determines the Level of Emergency Assistance? Media Coverage, Donor Interests and the Aid Business. Disasters 27 (2): 109-126.

Orbinski, James. 2008. An Imperfect Offering: Humanitarian Action in the $21^{\text {st }}$ Century. Canada: Doubleday.

Petersen, Andreas Hofer and Lise-Lotte Tullin. 2006. The Scorched Earth in Darfur: Patterns in Death and Destruction Reported by the People of Darfur January 2001-September 2005. Copenhagen: Bloodhound.

Posen, Barry. 1993. The Security Dilemma and Ethnic Conflict. Survival 35(1): 27-47.

Power, Samantha. 2004. Dying in Darfur: can ethnic cleansing in Sudan be stopped? The New Yorker. at:www.newyorker.com/archive/2004/08/30/040830fa_fact1 
--- 2008. Chasing the Flame: Sergio Vieira de Mello and the Fight to Save the World. New York: Penguin Press.

Prendergast, John, and Andrew Stroehlein. 2004. Don't breathe a sigh of relief for Sudan just yet. The Observer. http://www.guardian.co.uk/world/2004/jan/20/comment.theobserver

Prendergast, John. 2007. The Answer To Darfur: How to Resolve the World's Hottest War. Washington DC: Enough Project. [Strategy Paper 1]

Prendergast, John, and Colin Thomas-Jensen. 2007. Blowing the Horn. Foreign Affairs $86(2): 59-74$.

Prunier, Gerard. 2005. Darfur: The Ambiguous Genocide. Ithaca: Cornell University Press.

Rauchhaus, Robert W. 2005. Conflict management and the misapplication of moral hazard theory. Ethnopolitics 4(2):215-224.

Reeves, Eric. 2009. Roundtable Part 3: What Should Obama do about Darfur? The New Republic, March. http://www.tnr.com/politics/story.html?id=6f4929f2-dafa-4fb7$\underline{8 \mathrm{f} 65-5 \mathrm{f} 66 \mathrm{ad} 9 \mathrm{c} 4 \mathrm{dfc}}$

Richburg, Keith. 2002. Milosevic Attacks Court, Delays Formal Remarks, U.N. War Crimes Prosecutors Finish Opening Statement. Washington Post, February 14, A21.

Rowlands, Dane and David Carment. 1998. Moral Hazard and Conflict Intervention. In The Political Economy of War and Peace, ed. Murray Wolfson. Boston, MA: Kluwer Academic Press: 1-19.

Saeed, Mohamed Ali. 1995. Sudan steps up "popular defence" force training. France Presse. http://www.hartford-hwp.com/archives/33/014.html

Salih, Mohamed. 2005. Understanding the Conflict in Darfur. Copenhagen: Centre of African Studies, University of Copenhagen. [Occasional Paper]

Salla, Michael. 1995. Kosovo, Non-Violence and the Break-up of Yugoslavia. Security Dialogue 26(4): 427-438.

Slim, Hugo. 2004. Dithering over Darfur: A preliminary review of the international response. International Affairs 80(5):811-828.

Stewart, Frances. 2003. Income Distribution and Development. In Trade and Development: Directions for the 21st Century, edited by John Toye. Cheltenham: Edward Elgar. 
Straus, Scott. 2005. Darfur and the Genocide Debate. Foreign Affairs 84 (1): 123-33.

Sudan Liberation Army/Movement. 2003. Political Declaration, 14 March. http://www.sudan.net/news/press/postedr/214.shtml

Tabeau, Ewa, and Jakub Bijak. 2005. War-Related Deaths in the 1992-1995 Armed Conflicts in Bosnia and Herzegovina: A Critique of Previous Estimates and Recent Results. European Journal of Population 21: 187-215.

Tanner, Victor. 2005. Rule of Lawlessness: Roots and Repercussions of the Darfur Crisis. Interagency Paper. Washington DC: Sudan Advocacy Coalition.

Tanner, Victor and Jérôme Tubiana. 2007. Divided They Fall: The Fragmentation of Darfur's Rebel Groups. Small Arms Survey. Geneva: Graduate Institute of International Studies.

Tansey, Oisín. 2007. Process Tracing and Elite Interviewing: A Case for Non-Probability Sampling. Political Science 40 (4): 765-772.

UN Children's Fund (UNICEF). 2000. Multiple Indicator Cluster Survey 2000: Sudan. http://jam.unsudan.info/clusters/social/background-docs/MICS-Sudan-2000.pdf

UN Department of Peacekeeping Operations (DPKO). 1996. UN Protection Force (UNPROFOR). http://www.un.org/Depts/dpko/dpko/co mission/unprof p.htm.

--- 2008. The African Union/United Nations Hybrid Operation in Darfur (UNAMID). http://www.un.org/Depts/dpko/missions/unamid/

UN Development Group Office and the World Bank. 2006. Post Conflict Needs Assessment Review: Phase One: Sudan Joint Assessment Mission (JAM). www.undg.org/archive_docs/8882-

Sudan_PCNA_Case_Study_Lessons_Learned_Annex__Sudan_JAM_Case_Study.doc)

UN Development Program (UNDP). 2008. Human Development Index. UN Human Development Reports. http://hdr.undp.org/en/statistics/

UN Disaster Assessment Coordination (UNDAC). 2000. Field Handbook.

UN General Assembly. 1948. Convention of the Prevention and Punishment of the Crime of Genocide, Resolution 260 (III).

--- 2005. World Summit Outcome Document, A/60/L.1

UN Department of Public Information (UNDPI). 2008. Fifth Committee Takes Up Progress Report on \$1.5 Billion Budget of UNAMID for 2008/09, GA/AB/3885. http://www.un.org/News/Press/docs/2008/gaab3885.doc.htm 
United Nations High Commissioner for Refugees (UNHCR) and the World Food Program (WFP). 1998. Joint WFP/UNHCR Evaluation of Former Yugoslavia EMOP 5142 - Emergency Food Assistance to Returnees, Refugees, Displaced Persons and Other War-Affected Populations in Bosnia and Herzegovina.

UNHCR. 1998. UN Inter-Agency Update on Kosovo, Situation Report 59. http://www.reliefweb.int/rw/rwb.nsf/vLCE/77001302148A203CC1256678003362 D4?OpenDocument\&StartKey=Balkans\&ExpandView

--- 2008. Registered Refugee Camps Population: Eastern Chad. http://www.unhcr.org/publ/PUBL/481051b32.pdf

UN Integrated Regional Information Networks (IRIN). 2003. Sudan: Rights Groups Condemn Government Action on Darfur. Africa News, 30 April 2003.

UN News Service. 2003. Humanitarian and Security Situations in Western Sudan Reach New Lows, UN Agency Says. 5 December. www.un.org/apps/news/storyAr.asp?NewsID 1/4 9094\&Cr 1/4 sudan\&Cr1 1/4 .

UN Office for the Coordination of Humanitarian Affairs (OCHA). 2004. Darfur Humanitarian Profile No. 5, 1 August.

--- 2008. Darfur Humanitarian Profile No. 33, 1 October.

UN Population Fund (UNFPA) and Government of Sudan: Central Bureau for Statistics and the Federal Ministry of Health. 1999. Safe Motherhood Survey.

--- 2004. Women Suffer Brunt of Conflict in Western Sudan, UNFPA Warns. 04 May. http://www.unfpa.org/news/news.cfm?ID=447

UN Rome Statute. 2002. A/CONF.183/9, 1 July. http://untreaty.un.org/cod/icc/index.html

UN Secretary General. 1999. Report of the Secretary General on the UN Interim Administration Mission in Kosovo to the Security Council. S/1999/779, 12 July.

--- 2003. Secretary-General Alarmed by Deteriorating Humanitarian Situation in Darfur Region of Sudan. Press Release, 9 December.

http://www.un.org/News/Press/docs/2003/sgsm9067.doc.htm

UN Security Council (UNSC). 1999. Mandate of the UN Mission in Sierra Leone, Resolution 1270 (1999).

United States (US) Department of State. 1994. Human Rights Country Report, 1993. http://dosfan.lib.uic.edu/ERC/democracy/1993 hrp_report/93hrp_report_preface.h $\underline{\mathrm{tml}}$ 
--- 2004. Documenting Atrocities in Darfur - US State Department report on Darfur Genocide. http://www.reliefweb.int/rw/rwb.nsf/db900sid/KHII64S2UH?OpenDocument

US Department of Dispatch. 1992. Fact Sheet: Somalia - Operation Restore Hope, 21 December 1992: 898-899.

US Committee for Refugees and Immigrants (USCRI).1998. U.S. Committee for Refugees World Refugee Survey 1998 - Sudan. http://www.unhcr.org/refworld/docid/3ae6a8bb44.html

--- 1999. U.S. Committee for Refugees World Refugee Survey 1999 - Sudan. http://www.unhcr.org/refworld/docid/3ae6a8ccc.html

Valentino, Benjamin, Paul Huth, and Dylan Balch-Lindsay. 2004. Draining the Sea: Mass Killing, Guerrilla Warfare. International Organization 58(2): 375-407.

De Waal, Alex. 2004. Counter-Insurgency on the Cheap. Review of African Political Economy 31(102):716-725.

De Waal, Alex, and Julie Flint. 2005. Darfur: Short history of a long war. London: Zed Books. [Republished in 2008]

De Waal, Alex. 2007. Sudan: The Turbulent States. In War in Darfur and the Search for Peace, ed. De Waal, 1-38. Harvard: Harvard University Press.

De Waal, Alex, editor. 2007. War in Darfur and the Search for Peace. Harvard: Harvard University Press.

De Waal, Alex. 2008. Making Sense of Darfur. Social Science Research Council Blog, 13 May 2008, http://www.ssrc.org/blogs/darfur/2008/05/13/making-sense-of-khalilsputsch/

Wagner, Harrison. 2005. The hazards of thinking about moral hazard. Ethnopolitics 4 (2): $237-246$.

Weil, Carola. 2008. From Democratic Republic of Congo to Darfur: A Decade of Unintended Consequences of International Humanitarian Protection. Presentations at the International Studies Association's 49th Annual Convention, Bridging Multiple Divides, 26 March, San Francisco. http://www.allacademic.com/meta/p252785 index.html

Weinstein, Jeremy. 2007. Inside Rebellion: the Politics of Insurgent Violence. New York: Cambridge University Press. 
Weissman, Fabrice. 2007. Sudan Divided: The Challenge to Humanitarian Action.

Presentation at the Sudan Panel Discussion at Columbia University's School of International and Public Affairs, February 22, in New York City.

Western, Jon. 2002. Sources of Humanitarian Intervention: Beliefs, Information, and Advocacy in the U.S. Decisions on Somalia and Bosnia. International Security 26 (4): 112-142

--- 2005. Illusions of Moral Hazard: a Conceptual and Empirical Critique. Ethnopolitics 4(2): 225-236.

Wheeler, Nicholas. 2004. The humanitarian responsibilities of sovereignty: explaining the development of a new norm of military intervention for humanitarian purposes in international society. In Humanitarian Intervention and International Relations ed. J. M. Welsh, pp. 29-51. Oxford: Oxford University Press.

World Health Organization. 2004. Retrospective Mortality Survey Among the Internally Displaced Population Greater Darfur, Sudan. 2004. http://www.who.int/disasters/repo/14656.pdf 